UNIVERSIDADE DE SÃO PAULO

FACULDADE DE ECONOMIA, ADMINISTRAÇÃO E CONTABILIDADE DEPARTAMENTO DE ECONOMIA PROGRAMA DE PÓS-GRADUAÇÃO EM ECONOMIA

RACIONALIDADE E ORGANIZAÇÕES:

UM ESTUDO SOBRE COMPORTAMENTO ECONÔMICO NA OBRA DE HERBERT A. SIMON

Gustavo Barros

Orientadora: Profa. Dra. Ana Maria Afonso Ferreira Bianchi

SÃo PAULO

2004 
Prof. Dr. Adolpho José Melfi Reitor da Universidade de São Paulo

Profa. Dra. Maria Tereza Leme Fleury

Diretora da Faculdade de Economia, Administração e Contabilidade

Prof. Dr. Ricardo Abramovay

Chefe do Departamento de Economia

Profa. Dra. Basília Maria Baptista Aguirre

Profa. Dra. Fabiana Fontes Rocha

Coordenadoras do Programa de Pós-Graduação em Economia 


\title{
GUSTAVO BARROS
}

RACIONALIDADE E ORGANIZAÇÕES:

UM ESTUDO SOBRE COMPORTAMENTO ECONÔMICO

NA OBRA DE HERBERT A. SIMON

\begin{abstract}
Dissertação apresentada ao Departamento de Economia da Faculdade de Economia, Administração e Ciências Contábeis da Universidade de São Paulo como requisito para a obtenção do título de Mestre em Economia.
\end{abstract}

Orientadora: Profa. Dra. Ana Maria Afonso Ferreira Bianchi 
Dissertação defendida e aprovada no Departamento de Economia da Faculdade de Economia, Administração e Contabilidade da Universidade de São Paulo - Programa de Pós-Graduação em Economia, pela seguinte banca examinadora:

Racionalidade e organizações : um estudo sobre comportamento econômico na obra de Herbert A. Simon / Gustavo Barros. -- São Paulo, 2004.

$145 \mathrm{f}$.

Dissertação (Mestrado) - Universidade de São Paulo, 2004 Bibliografia.

1. Herbert A. Simon 2. Economia 3. Economia (História) 4. Pesquisa operacional (História) 5. Comportamento (Economia) I. Faculdade de Economia, Administração e Contabilidade da USP.

II. Título. 
Algumas pessoas muito me ajudaram ao longo deste trabalho. Queria agradecer especialmente aos professores Gilberto Tadeu Lima e Jorge Eduardo de Castro Soromenho, tanto pela participação na banca de qualificação, quanto pelas ótimas conversas que se seguiram a ela. Gostaria de agradecer também ao Prof. José Raimundo Novaes Chiappin, ao Prof. Raul Cristóvão dos Santos, à Profa. Heloisa Helena Teixeira de Souza Martins e ao Prof. Antonio Maria da Silveira que, cada um à sua maneira, me guiaram no caminho. Ao Rudy pela leitura atenta e comentários. À Márcia pela paciência... Agradeço também à minha orientadora Profa. Ana Maria Afonso Ferreira Bianchi.

Este trabalho foi realizado com apoio da CAPES e da FIPE. 


\section{RESUMO}

Neste estudo é feita uma apresentação de alguns aspectos da obra de Herbert A. Simon que foram julgados de particular importância para a economia. A teoria comportamental do autor é o eixo em torno do qual estes aspectos resultaram girar. Esta teoria por sua vez foi aqui dividida em dois temas: o da racionalidade e o da organização. Estes temas são duas partes essenciais da teoria e devem caminhar sempre juntos no sentido de que, respectivamente, tratam da estrutura da teoria e do contexto ao qual ela se aplica.

No que diz respeito ao tema da racionalidade, são tratados aqui os argumentos de Simon relativos às restrições ao exercício da racionalidade pelos agentes associadas às suas capacidades cognitivas. Em particular, Simon argumenta que a hipótese de onisciência, implicada pelas hipóteses de racionalidade da teoria econômica neoclássica, gera problemas para a teoria, tanto em sua faceta normativa quanto na positiva. São também apresentados os conceitos de racionalidade restrita e de racionalidade procedimental. Este último foi desenvolvido por Simon a partir do primeiro, tendo em vista principalmente as dificuldades da teoria econômica de lidar com situações de incerteza.

$\mathrm{Na}$ medida em que as restrições à racionalidade são admitidas pela teoria, o comportamento passa a depender fortemente tanto do contexto em que ocorre quanto das características psicológicas (cognitivas) do agente. Grande parte do trabalho de Simon em economia girou em torno do conceito de organização. De fato, organizações constituem um contexto predominante do comportamento econômico, tanto mais quanto grandes organizações têm dominado o cenário nas últimas décadas. Neste sentido, é questionada também a predominância do conceito de mercado sobre o de organização na teoria. Esta dependência que o comportamento econômico tem do contexto leva Simon a argumentar em favor de uma aproximação entre economia e empiria, em particular do estudo empírico de como o comportamento se dá na prática - ou seja, onde empiria não deve ser tomada como sinônimo de econometria.

Uma contextualização histórica do trabalho de Simon também foi realizada. Foram explorados aí alguns temas. Primeiro, foi conceituado o "regime da Segunda Guerra Mundial" surgido em torno da confluência entre as empreitadas científica e militar durante a Segunda Guerra. Em segundo lugar, a importância deste regime para a carreira de Simon foi discutida, em particular a disponibilidade do computador, a partir de meados da década de 1950, para sua pesquisa. Em terceiro lugar, foi identificada e descrita como importante manifestação desse regime a "pesquisa operacional" e foram traçadas algumas de suas implicações para a economia em particular e, de maneira mais vaga, para as ciências sociais em geral. 


\section{ABSTRACT}

This study presents some aspects of Herbert A. Simon's work that were thought to have particular importance to economics. The author's behavioral theory is the axis around which these aspects orbit. This theory, in turn, was divided here into two themes: rationality and organization. Both of them are essential parts of the theory and always work hand in hand in the sense that, respectively, they are the structure of the theory and the context to which it applies.

Concerning rationality, Simon's arguments about the constraints to the exercise of rationality related to the agents' cognitive limitations are presented. In particular, he argues that the hypothesis of omniscience, implied by the neoclassical economic theory hypothesis of rationality, causes trouble to the theory, in either its normative or positive side. The concepts of bounded rationality and procedural rationality are also presented. The latter was developed by Simon based on the former in an attempt to circumvent the difficulties of the economic theory to deal properly with uncertainty.

When the bounds to rationality are admitted by the theory, behavior then depends strongly on the context in which it occurs and on the agent's psychological (cognitive) characteristics. A major part of Simon's work in economics dealt with the concept of organization. Indeed, organizations constitute a predominant context to economic behavior, especially when we consider the role large organizations have been playing in the last decades. Proceeding in that line of thought, the preponderance in economics of the concept of market over the concept of organization is questioned. The aforementioned dependency of behavior to the context leads Simon to argue in favor of an approximation of economics and empiric work, especially concerning how behavior is to be found in practice - or else, where empiric work is not to be taken as synonym for econometrics.

Simon's work was historically contextualized and some themes were explored as related to this context. First, the "World War II regime", emerging out of a confluence of the military and scientific enterprises in the war, was conceptualized. Second, the importance of this regime to Simon's career was stressed, and particularly important was the availability of the computer for his research from the mid-fifties on. Third, an important manifestation of this regime, "operations research", was identified and described. Some of its implications for economics in particular and, in a vaguer manner, for the social sciences in general were also traced. 


\section{Sumário}

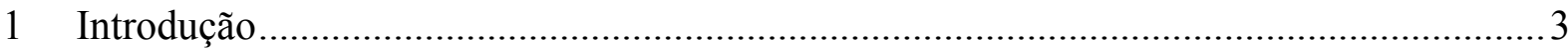

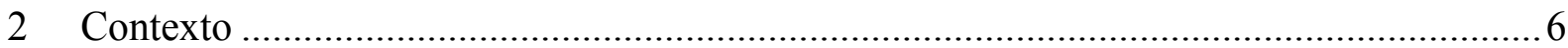

2.1 Biografia e história e biografia e história ........................................................... 6

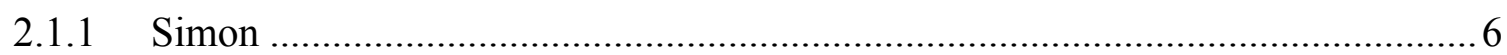

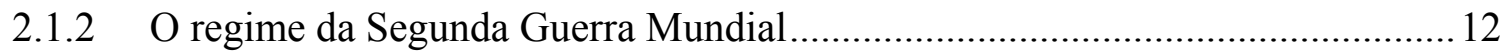

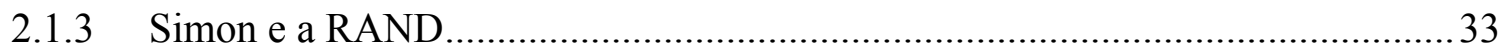

2.1.4 Simon, pesquisa operacional e ciências sociais ................................................ 38

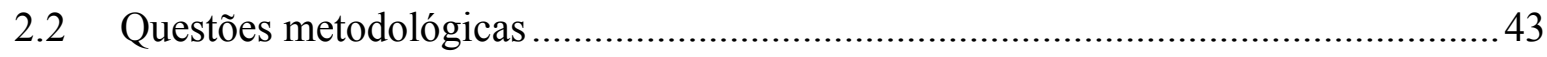

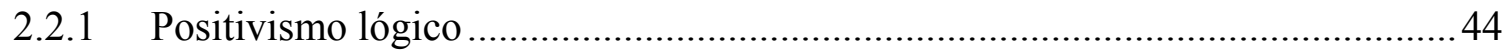

2.2.2 Racionalismo e individualismo metodológico ............................................... 48

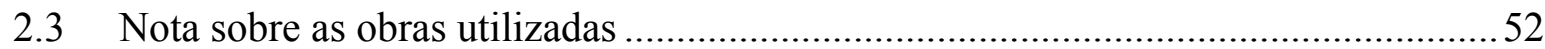

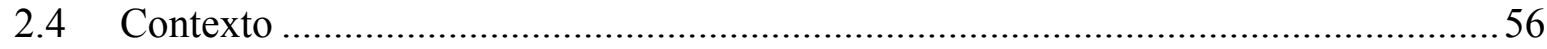

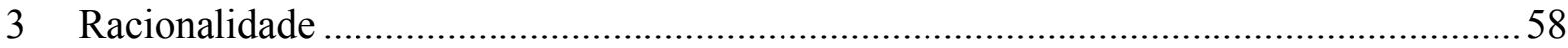

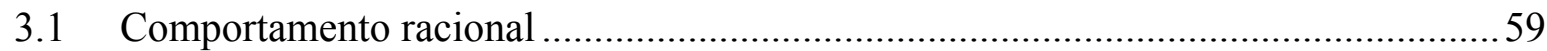

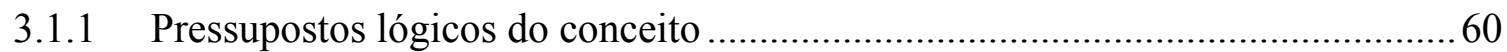

3.1.2 Comportamento (objetivamente) racional ...................................................... 61

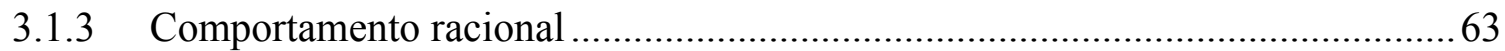

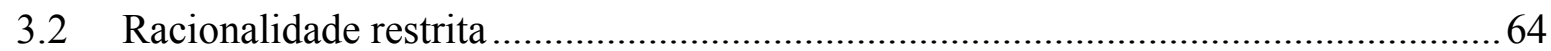

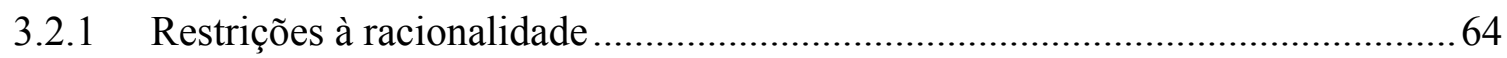

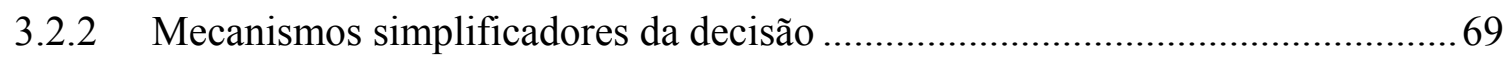

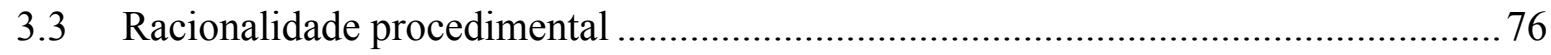

3.3.1 Racionalidade procedimental e racionalidade substantiva..............................78

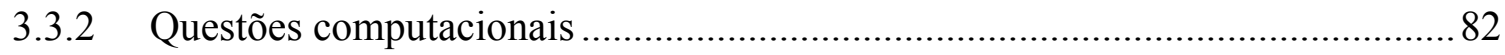




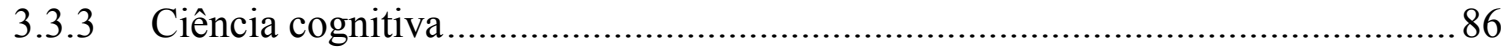

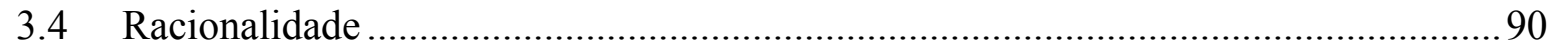

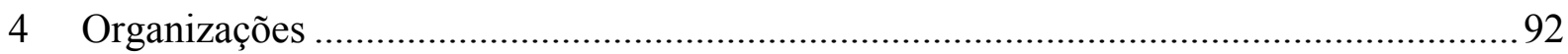

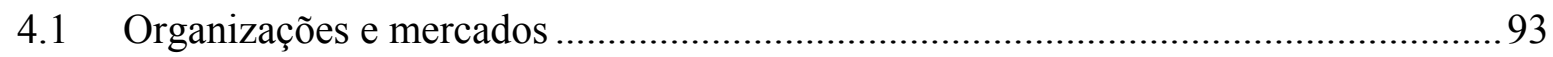

4.1.1 Identificação e autoridade: meios de coordenação.......................................... 94

4.1.2 Centralização e descentralização: eficiência relativa de mercados e

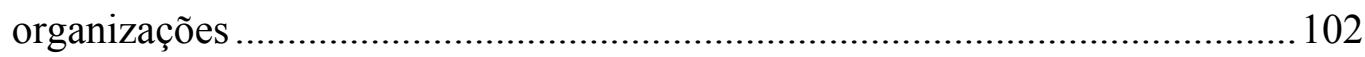

4.2 Nota sobre o conceito de organização................................................................ 107

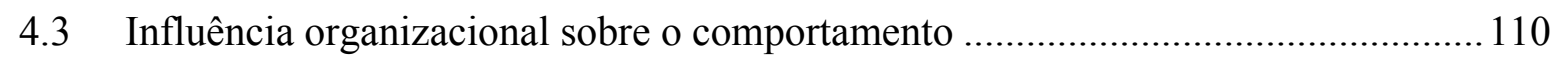

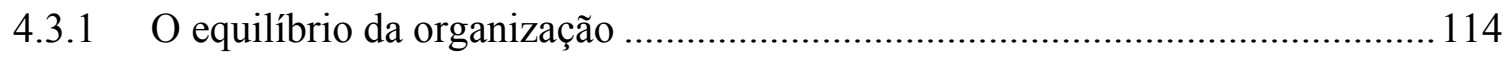

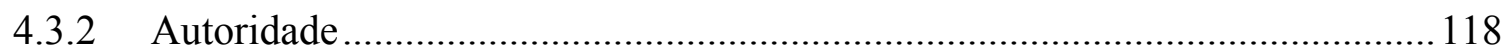

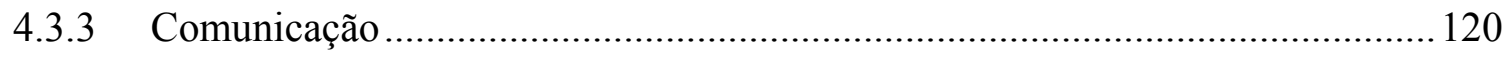

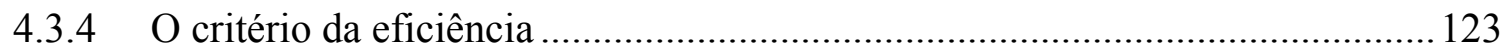

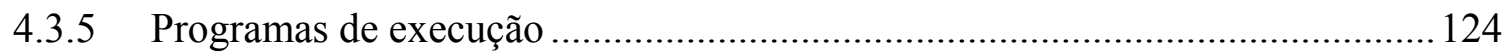

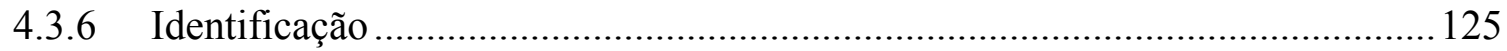

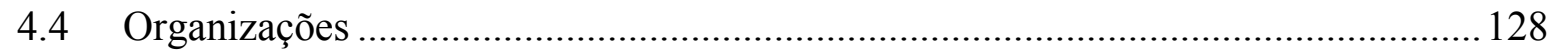

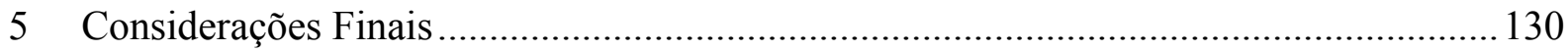

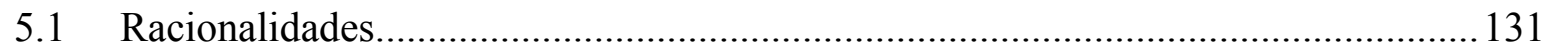

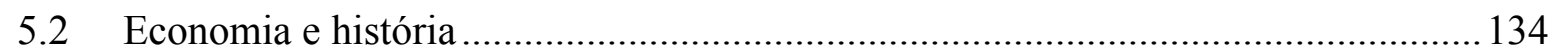

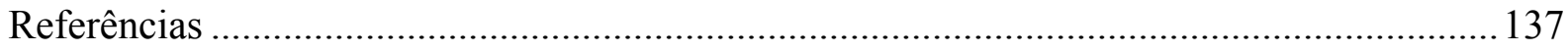

Trabalhos de Herbert A. Simon .................................................................................. 137

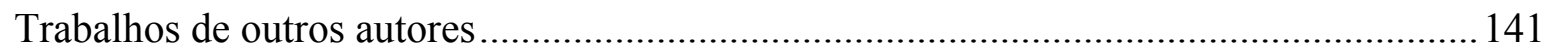




\section{Introdução}

Herbert A. Simon recebeu, em 1978, o Prêmio Nobel de Economia "por sua pesquisa pioneira sobre o processo de tomada de decisão no interior de organizações econômicas" (Royal Academy, 1979: 72). De fato, o processo de tomada de decisões no interior de organizações econômicas representa o cerne dos esforços de Simon no que diz respeito à teoria econômica. Mas acredito ser melhor pensar esta contribuição como algo mais que um complemento à teoria da firma. É mais interessante pensá-la como a fonte de uma importante alternativa teórica atual aos pressupostos comportamentais da teoria econômica neoclássica. ${ }^{1}$

Um dos principais temas pelo qual Simon é conhecido é o das restrições à racionalidade. Houve momentos em que a penetração desse argumento na economia parecia à míngua: "[Ao final da década de 1960] a racionalidade restrita parecia estar morrendo uma morte quieta, ao menos nos Estados Unidos. Os neoclássicos claramente tinham ganho a disputa" (Simon, 1996a: 319). Mas mais recentemente, já podemos encontrar manifestações como a de John Conlisk, que faz um bom apanhado da literatura em torno do conceito de racionalidade restrita num importante periódico da disciplina. Conlisk (1996) responde à pergunta "Por que racionalidade restrita?" com quatro argumentos. Primeiro, há ampla e abundante evidência empírica, suprida pela economia e pela psicologia, da importância da racionalidade restrita. Segundo, a utilização da racionalidade restrita por economistas tem se mostrado muito bem sucedida na descrição do comportamento econômico num escopo mais amplo do que o permitido pela teoria padrão. Em terceiro lugar, os argumentos metodológicos tipicamente movidos em favor de desconsiderar as restrições à racionalidade não se sustentam em todos os casos, e a pertinência de uma ou outra hipótese deve ser avaliada pelas condições do contexto particular. E, por último, a deliberação envolvida numa decisão econômica é uma atividade custosa: a cognição humana é um recurso escasso e deve ser tratado pela economia como tal.

Simon, o "profeta da racionalidade restrita", já insistia no argumento das restrições à racionalidade ao menos desde a década de 1940 e trabalhou continuamente em sua carreira

\footnotetext{
${ }^{1}$ Silveira (1983: 599) aponta o trabalho de Simon como "uma potencial revolução para a economia".

${ }^{2}$ Simon (1996a: 250) e Sent (1997: 323).
} 
para fundamentá-lo e divulgá-lo. Esse foi o seu principal mote teórico na economia, no entanto, Simon, não era apenas, e nem mesmo principalmente, um economista. Era chamado de "um cientista social no sentido amplo do termo", "um verdadeiro homem da Renascença". De fato, ele atuou sistematicamente em diversas disciplinas, entre elas a economia, a psicologia e a ciência da computação. Mas, por outro lado, através de toda esta diversidade disciplinar encontramos uma constante preocupação com a tomada de decisão e a solução de problemas.

Dito isso, o objetivo deste estudo é modesto. Trata-se de compilar e organizar alguns dos aspectos mais importantes obra de Simon do ponto de vista da economia. Algumas considerações sobre o objetivo proposto são pertinentes. Primeiro, a compilação aqui realizada do trabalho de Simon é seletiva: muitos tópicos que poderiam, com maior ou menor grau de relevância, ser incluídos neste trabalho foram deixados de lado. Simon se envolveu com, e fez contribuições de peso para, diversas disciplinas, inclusive ajudando a fundar algumas. Em meio a esta interdisciplinaridade há alguns temas mais gerais que perpassam toda a obra do cientista, e alguma referência explícita é feita aqui a alguns deles, embora o ponto de vista da ciência econômica tenha sido privilegiado. Na apresentação da teoria, ao menos, tentei encontrar um equilíbrio entre os arroubos expedicionários de Simon e o quadro de referência relativamente contido do economista típico. Segundo, uma das coisas que esta proposta permite é fornecer para os interessados uma visão introdutória integrada do trabalho de Simon, que se encontra disperso em diversas de publicações, naqueles aspectos que julgo mais relevantes para os economistas. Este estudo deve atender tanto àqueles que desejam restringir-se a uma visão mais superficial, porém consistente, quanto àqueles que desejam uma porta de entrada ao trabalho deste inventivo cientista. Por esta razão também, especial cuidado será tomado na contextualização dos trabalhos particulares do autor que foram selecionados como "linhas mestras" deste estudo. Por último, mas não menos importante, um bom entendimento da obra de Simon, e das mudanças pelas quais passou, demanda inseri-la num contexto histórico apropriado. A contextualização aqui realizada permite tanto compreender a importância do momento histórico vivido por Simon para a sua obra quanto usar Simon para pensar sobre alguns dos processos históricos então em andamento. 
O eixo organizador deste estudo será a teoria comportamental de Simon. Trata-se de uma teoria do comportamento racional, e tem como um postulado central o conceito de satisfazimento. ${ }^{3}$ A idéia geral é a de que os homens possuem a intenção de racionalidade, no entanto, em função de suas limitações cognitivas e computacionais, não conseguem escolher uma alternativa ótima, mas escolhem uma suficientemente boa, aceitável. A racionalidade dos homens é restrita por suas capacidades cognitivas e computacionais. Eles não maximizam, mas satisfacem.

O conflito desta proposição com a teoria econômica neoclássica é evidente, já as conseqüências dela para a economia nem tanto. Em primeiro lugar, a psicologia do agente, suas características cognitivas e computacionais, são colocadas no centro da análise, quando eram totalmente excluídas dela. Em segundo lugar, a observação empírica assume outro papel, e é trazida do confronto com os resultados dedutivos finais da teoria para a discussão de seus pressupostos comportamentais e para a construção de um contexto comportamental. Num sentido amplo, a teoria comportamental de Simon exige dos economistas uma outra maneira de pensar sobre a economia que, podemos dizer, é um pouco mais "concreta".

Esclarecidas as intenções, podemos passar à estrutura do trabalho. $\mathrm{O}$ principal assunto do segundo capítulo é a contextualização histórica, mas trataremos também ali de algumas considerações metodológicas, tanto da obra de Simon quanto deste estudo. O terceiro capítulo discute as questões em torno da racionalidade, a parte estrutural da teoria comportamental do autor. São apresentados e discutidos os conceitos de racionalidade restrita e racionalidade procedimental, bem como algumas de suas implicações. O quarto capítulo trata de organizações, que constituem um dos contextos predominantes do comportamento econômico. São tratados os diversos modos de influência organizacional sobre o comportamento e os méritos do conceito de organização com relação ao conceito de mercado para a economia são discutidos. Nas considerações finais é feita uma tentativa de destilar a concepção de racionalidade de Simon e de traçar as implicações de sua teoria para a relação entre economia e história.

\footnotetext{
${ }^{3}$ Adoto a tradução, que considero apropriada, de Silveira (1983) para o termo satisficing.
} 


\section{Contexto}

Este capítulo trata do pano de fundo no qual se apresentará a teoria comportamental de Simon. Primeiramente, discorrerei sobre o contexto histórico e biográfico no qual deve ser encaixada a obra do cientista. Em seguida, farei algumas considerações sobre aspectos metodológicos gerais, tentando caracterizar a visão que Simon tinha de ciência. Finalmente, tratarei dos aspectos metodológicos desta dissertação.

\subsection{Biografia e história e biografia e história}

Esta seção se dedica à contextualização biográfica e histórica do trabalho de Simon e exploro aqui quatro temas interconectados: uma caracterização um pouco mais personalista de Simon e de sua herança intelectual, uma discussão bastante ampla de algumas transformações que marcaram a atividade científica nos EUA a partir da Segunda Guerra, a passagem de Simon pela Rand Corporation e a influência desta passagem na sua carreira, e as tentativas políticas de Simon influenciar as ciências sociais. A organização da seção é propositalmente pouco linear e oscila entre o particular e o geral no sentido de ressaltar a interação entre os temas.

\subsubsection{Simon}

Herbert Alexander Simon, cientista norte-americano, nasceu em 1916, em Milwakee, Wisconsin, e viveu até os 84 anos, numa longa e extremamente produtiva carreira profissional, durante a qual publicou cerca de 27 livros e mais de 600 artigos (Sent, 2001b). ${ }^{4}$ Não apenas o volume, mas a diversidade também impressiona. Simon atuou sistematicamente em várias áreas de conhecimento ao longo de sua vida: psicologia (cognitiva), inteligência artificial, ciências da computação, administração, economia e ciência política. Além disso, ele

\footnotetext{
${ }^{4}$ A extensa bibliografia de Simon pode ser encontrada em alguns lugares diferentes. Por ocasião do Prêmio Nobel, alguns compêndios foram organizados, entre eles Silveira (1983) e um outro publicado no Scand. J. Economics (1979). No entanto, nenhuma das duas cobre o período mais recente. A mais extensiva bibliografia que encontrei encontra-se no sítio do departamento de psicologia da Carnegie-Mellon University: $<$ http://www.psy.cmu.edu/psy/faculty/hsimon/hsimon.html >, acessado em 13/09/04.
} 
deixou sua marca em outras áreas ainda. ${ }^{5}$ De fato, ele era reverenciado por sua interdisciplinaridade e, seguramente, era intelectualmente intimidante. ${ }^{6}$ É comum tomar Simon, como faz Silveira (1983: 587), como um "cientista social no sentido amplo do termo", no entanto, suspeito que este rótulo seja um que os economistas costumam atribuir a ele. Sua reputação dava margem a comentários do seguinte tipo:

Richard M. Cyert era Dean da GSIA [Graduate School of Industrial Administration], durante o meu período de aluno ..., e creio que suas palavras sobre Simon não seriam questionadas por professores e alunos da época: 'o único homem no mundo que chega mais perto do ideal de Aristóteles ou de um homem da Renascença'. (Silveira, 1983: $589)^{7}$

Mas, ressalva Silveira, "o comum era a colocação de Simon no nível de Keynes, como um dos grandes cientistas sociais do século" (1983: 589). ${ }^{8}$ De qualquer maneira, cabe reter o fato de que Simon não era apenas, e nem principalmente, um economista. Possuía, de fato, um intelecto respeitável e não era dado a se acomodar no interior de barreiras disciplinares.

Simon atuou em diversas instituições de ensino e de pesquisa: University of California at Berkeley, Illinois Institute of Technology, Comissão Cowles, Rand Corporation, e Carnegie-Mellon University. Recebeu também os mais importantes prêmios nas áreas em que fez contribuições, entre eles o prêmio Nobel de Economia e o Turing Award, de Computação. ${ }^{9}$

O pai, Arthur Simon, um judeu alemão que emigrou para os Estados Unidos nos primeiros anos do século XX, era um engenheiro elétrico dado a invenções. ${ }^{10}$ A mãe, Edna Marguerite Merkel, também de família de origem alemã, foi pianista e dona-de-casa. Herbert, segundo e último filho, era "incorrigivelmente introspectivo", e desde cedo tomou gosto pelos

\footnotetext{
${ }^{5}$ Outras áreas que são citadas em referências a ele são: filosofia, metodologia da ciência, matemática aplicada, estatística.

${ }^{6}$ Embora não pessoalmente intimidante, como testemunha Silveira (1983: 590) que foi aluno da Graduate School of Industrial Administration (GSIA) na década de 1960: "Minha percepção era de que tanto os alunos de administração como os de economia viam Simon como admi, acima das tribos desta nação, mas talvez oriundo da orga, superando ainda as barreiras nacionalistas, sendo capaz de transitar livremente, sem passaporte, entre os econs, psics, comps, etc., tanto por ser confundido como um deles, quanto pelo respeito ou temor que impunha, ou ainda pelo 'crédito idiossincrático' de que já gozava. [nota:] Não se pode ignorar também a extrema simpatia e simplicidade de Simon."

${ }^{7}$ Mais adiante temos: "Trata-se reconhecidamente de um gênio..." (Silveira, 1983: 602)

${ }^{8}$ Albert Ando (1979: 92-93) também compara Simon com Keynes.

${ }^{9}$ Sent (2001b) apresenta uma lista mais detalhada.

${ }^{10}$ As principais fontes biográficas que utilizo aqui são: Simon (1978b) e Sent (1998, 2001b), e em especial a autobiografia de Simon (1996a).
} 
livros e pelo autodidatismo. Tinha também inclinação para o debate acalorado, e não era exatamente modesto. Simon se casou com Dorothea Pye no ano de 1937, aos 21 anos de idade, e eles tiveram três filhos.

Simon iniciou seus estudos superiores na Universidade de Chicago, tendo obtido o B.A. em Ciência Política em 1936, ${ }^{11}$ e o Ph.D., na mesma área, em 1942. Já nessa época, a sua formação era bastante ampla. Tinha "lido amplamente nas humanidades", tinha reforçado sua base de biologia e física, tinha um bom conhecimento introdutório de sociologia e antropologia, e um não tão bom de psicologia, e tinha um treinamento mais elaborado em ciência política e economia (Simon, 1996a: 51). ${ }^{12}$

Se quiséssemos traçar os contornos de uma herança intelectual de Simon a lista provavelmente incluiria os seguintes nomes: Harold Merkel, Chester Barnard, John R. Commons, Charles E. Merriam, Henry Schultz, Nicolas Rashevsky, Rudolf Carnap, William James, Edward C. Tolman e Frank Knight. A título de esboço, sugiro aqui apenas alguns elos, a partir da referência que o próprio Simon faz a seus "antecessores", mas não irei muito além, tanto por desconhecer a obra de todos eles, o que torna difícil avaliar a importância das influências, quanto por desconsiderar outras influências eventualmente relevantes. Além disso, baseando-me apenas nos relatos de Simon não terei como distinguir pessoas importantes na formação pessoal dele de fontes originais de conjuntos de idéias.

Harold Merkel, tio materno de Simon, embora tenha falecido quando Simon tinha apenas seis anos, forneceu, digamos, um modelo intelectual familiar. Harold graduou-se com distinção em direito na Universidade de Wisconsin e foi aluno (de economia) de John Commons e Richard T. Ely. Os livros do tio ficaram na casa da irmã, dando a Simon acesso temporão a títulos como Os Federalistas e Psychology de William James. ${ }^{13}$ Dele também foi herdado o gosto pelo debate formal inflamado. Mas a influência do tio foi mais longe do que isso, segundo Simon (1996a: 18), ele foi responsável pela sua exposição à idéia de que "o

\footnotetext{
11 Embora ele tenha deixado de se graduar em economia simplesmente porque não quis cumprir créditos obrigatórios em contabilidade: "I resolved to major in economics, until I learned it required an accounting course. I switched to political science, which had no such requirement." (Simon, 1996a: 39)

12 Ao final do Ph.D. ele já possuía "um excelente treinamento em ciência política e uma fundação sólida em economia", e "tinha feito uma modesta iniciação à matemática, o suficiente para a auto-instrução" (Simon, 1996a: 85).

${ }^{13}$ Outros livros que Simon menciona ter lido cedo são: Progress and poverty de Henry George, Outline of economics de Richard T. Ely, The great illusion de Norman Angell, Elements of physical biology de Alfred Lotka.
} 
comportamento humano podia ser estudado cientificamente" e permitiu-lhe vislumbrar "o desafio de trazer às ciências sociais ou à biologia o pensamento matemático que havia sido tão poderoso na física".

Chester I. Barnard escreveu The Functions of the Executive (1938), livro que forneceu a Simon a principal fonte de inspiração para escrever sua dissertação de Ph.D., que mais tarde se tornaria Administrative Behavior (Simon, 1947). Simon via Barnard como um "executivo curioso intelectualmente", e o livro deste foi a origem de diversos dos conceitos centrais para o de Simon, como as noções de autoridade, de zona de indiferença ou aceitação e a de equilíbrio organizacional de induções e contribuições (Simon, 1996a: 85-88; Sent, 1999). ${ }^{14}$ O importante conceito de identificação organizacional também estava presente na obra de Barnard, mas Simon "já havia chegado a ele antes [de ler Barnard]”.

O próprio Barnard havia sido substancialmente influenciado por Commons e Simon (1979a: 499) identifica na tradição institucionalista, por diversificada que fosse, os principais precursores de uma teoria comportamental da firma. Commons é destacado como fonte de "muitos insights em [seus] estudos iniciais sobre a tomada de decisão organizacional". ${ }^{15}$ Em particular, se em algum lugar Simon reconhece a "fonte" da racionalidade restrita, é na obra de Commons: ${ }^{16}$

The other central idea in my book that appears in only mute form in Barnard's is bounded rationality. The closest parallel is Barnard's notion of opportunism and strategic factors, ideas that he derives from John R. Commons. Since I had also read Commons, the latter's Institutional Economics may have been a common source for these various conceptions of rationality that deviate from the economists' maximization of subjective expected utility. (Simon, 1996a: 87) ${ }^{17}$

Talvez o mais apropriado não seja atribuir uma herança intelectual direta a Simon oriunda de Charles Merriam, mas sim do ambiente vivido por ele na Universidade de Chicago, e em especial no departamento de ciência política, do qual Merriam era "o chefe". ${ }^{18}$ A esta experiência, a seus tempos de Chicago, Simon dedica dois capítulos de sua

\footnotetext{
${ }^{14}$ Barnard também comentou o manuscrito de Simon e prefaciou a primeira edição de Administrative Behavior. O prefácio, segundo Simon, certamente colaborou para a boa recepção do livro. O próprio Simon (1979a) credita Barnard: "The numerous references to Barnard's work in Administrative Behavior attest, though inadequately, to the impact he had on my own thinking about organizations." (p. 499-500)

${ }^{15}$ Thorstein Veblen é também ocasionalmente citado por Simon.

${ }^{16}$ Veja também March e Simon (1958: 169).

${ }^{17}$ Embora o termo "bounded rationality" só tenha aparecido em Simon (1957) (Klaes e Sent, 2002).
} 
autobiografia. Duas coisas me parecem interessantes para os propósitos em vista: a intensidade do ambiente na Universidade, e o movimento intelectual que estava em curso no seu departamento de ciência política na época. O ambiente da Universidade propiciava ampla exposição a novidades e agitação intelectual. ${ }^{19}$

À diversidade do ambiente se somava o trabalho duro, a princípio seguindo o exemplo dos alunos da pós-graduação. Simon (1996a: 41) relata que, durante os primeiros anos da graduação, viveu "como um intelectual", envolvido em livros e em conversas sobre livros do despertar ao adormecer, sete dias por semana.

Segundo Simon (1996a: 55), o departamento de ciência política da Universidade, sob a liderança de Merriam, era então vanguarda do comportamentalismo que veio a transformar a disciplina nas décadas seguintes. ${ }^{20}$ Além de Merriam, sobressaiam-se no departamento Harold Gosnell, Harold Lasswell e Frederick Schuman. "Eram os métodos psicologizantes de Lasswell e os métodos quantitativos e empíricos de Gosnell que simbolizavam a Escola de Chicago de maneira mais específica" (Simon, 1996a: 60). Na percepção de Simon (1996a: 5559), as mudanças que então se engendravam ali vinham num sentido de afirmar os fenômenos políticos como objetos de estudo científico, passando da filosofia moral para a descrição empírica. A vivência deste momento deu-lhe uma visão "de como as disciplinas científicas se desenvolvem" e o ensinaram "as estratégias de subversão que [ele] mais tarde [empregou] ao atacar a ortodoxia na economia e na psicologia" (Simon, 1996a: 55).

Além dos professores do departamento de ciência política, Simon (1996a: 51-54) destaca três outros da Universidade de Chicago com quem aprendeu a aplicar matemática a problemas empíricos: Henry Schultz, Rudolf Carnap e Nicolas Rashevsky. "Todos os três homens me comunicavam em suas conferências algo de como ciência - ao menos ciência

\footnotetext{
${ }^{18}$ Não se pode descartar, no entanto, que Dorothea Pye, com quem Simon veio a se casar, era secretária de Merrian e aluna do departamento na época.

19 No depoimento de Simon: "When I arrived at the University of Chicago in 1933, it was all the things artistically, intellectually, and politically - that Milwakee was not. Nothing was too new, too arcane, or too absurd to excite passionately the bright minds of the students and faculty assembled on the Midway campus. Everything had to be explored, tested, before it could be accepted or rejected." (Simon, 1996a: 36)

${ }^{20} \mathrm{O}$ estilo de Merriam também parece ressoar em Simon: "There is no Merriamic political science. Political science of the Chicago School provided a goal - to understand political behavior and political processes - and some directions to approach it: data and theories in psychology, economics, and the other social sciences and the modern techniques of experimentation, statistical analysis, and mathematical modeling. There were plenty of problems to which these data, theory and techniques could be applied, but no simple template for applying them and no guarantee of the form results would take." (Simon, 1996a: 62)
} 
envolvendo a aplicação de matemática - era feita" (Simon, 1996a: 53). Simon credita a Shultz o seu entendimento da teoria de equilíbrio geral walrasiana e da teoria de testes estatísticos de Neyman-Pearson, bem como sua apreciação pela importância e dificuldade do problema de identificação. Rashevsky tinha "um talento maravilhoso para colocar suposições simples em modelos de sistemas biológicos". Carnap foi especialmente importante, tendo sido professor de lógica de Simon, forneceu-lhe sua concepção "concreta" do pensamento enquanto manipulação de símbolos: ${ }^{21}$

By example, [formal logic] demonstrated that manipulating symbols is as concrete as sawing pine boards in a carpentry shop; symbols can be copied, compared, rearranged, and chunked just as definitely as boards can be sawed, planed, measured and glued. (Simon, 1996a: 193)

Entre os psicólogos, William James e Edward C. Tolman podem ser contados entre as principais influências. Ambos são citados com destaque em Administrative Behavior (Simon, 1947). James aparece com alguma regularidade em outras obras ao longo de toda a carreira de Simon, no entanto este atribui a Tolman a analogia entre a tomada de decisão e o labirinto (1996a: 86). Silveira (1996: 121) sugere também Frank Knight como um precursor de Simon, ao que este último lhe responde em carta:

Se tivesse que dar um palpite sobre o impacto que pudesse ter tido em mim, seria no de reforçar uma convicção: a teoria da racionalidade tinha que lidar não apenas com risco e incerteza, no sentido comum, mas também na forma particular de incerteza que aparece na interação de indivíduos com objetivos parcialmente conflitantes, incerteza teórica de jogos. Eu certamente não faria objeções ao pensamento de ter em Frank Knight um predecessor espiritual. (Simon apud Silveira, 1996: 133)

Quando Simon completou seu Ph.D., em maio de 1942, fazia poucos meses que os Estados Unidos haviam entrado na Segunda Guerra Mundial em função do ataque a Pearl Harbor, a 7 de dezembro de 1941. Ele, apesar de intervencionista fervoroso desde antes deste evento, permaneceu como civil durante a Guerra em função de seu daltonismo. No entanto, a Segunda Guerra e suas conseqüências subseqüentes tiveram influências fundamentais na carreira de Simon, fornecendo-lhe novas possibilidades e colocando sobre ele novas demandas. E dando-lhe uma segunda "herança" intelectual.

\footnotetext{
${ }^{21}$ Voltaremos ainda a falar das influências de Carnap sobre Simon.
} 


\subsubsection{O regime da Segunda Guerra Mundial}

Que a Segunda Guerra mundial é um marco de muitas e importantes mudanças, operadas em diversas esferas, quase no mundo inteiro, e em especial na sociedade norteamericana, é uma afirmação que hoje em dia parece ser pouco disputada. Quando vamos aos particulares da proposição, no entanto, as coisas costumam ficar mais complicadas. A história de senso comum das ciências, por exemplo, parece ser freqüentemente contada como se a Guerra tivesse sido um simples interlúdio, onde os cientistas interromperam suas atividades para contribuir com o seu quinhão no esforço de guerra. Findo o combate, todavia, retomaram do ponto onde haviam parado, exceto pelo prestígio (e orçamento) muito ampliado em função do papel crucial que tiveram, em especial físicos e matemáticos, na vitória dos aliados. Alguns frutos desta participação são notórios: o radar, o computador, a bomba atômica. Não é necessário muita sagacidade para rotular esta versão de simplista $^{22}$ no entanto parece que tivemos que esperar o fim da Guerra Fria para ir adiante.

Há hoje um corpo de literatura, já não tão recente, ${ }^{23}$ compilado em Mirowski e Sent (2002) e referido em Mirowski (1999), que examina as mudanças perpetradas na organização e no financiamento das ciências naturais nos Estados Unidos a partir da Segunda Guerra e se estendendo pelo período da Guerra Fria. Um dos principais temas desta literatura são as profundas mudanças na forma e conteúdo da ciência no pós-guerra associadas à completa reformulação da política científica, do planejamento e do financiamento estatais (com destaque para o patrocínio militar) da pesquisa nos EUA (Mirowski, 1999: 685). A Segunda Guerra foi um ponto de descontinuidade na história em muitos sentidos. Foi, em particular, divisor de águas para a ciência norte-americana (Mirowski e Sent, 2002: 15-16). ${ }^{24}$

\footnotetext{
${ }^{22}$ Uma versão um pouco, não muito, mais refinada afirma que a mudança foi de "tamanho": “... the only sort of change [Science has undergone over the course of the twentieth century] that many commentators on the health and well-being of Science deign to recognize is that there has been but more of the same. In other words, in this simple but widespread view, progressively larger phalanxes of scientists produce progressively more 'knowledge' that is poured in a vast communal storage tank of information ..." (Mirowski e Sent, 2002: 10)

${ }^{23}$ A literatura sobre o assunto referida por Mirowski e Sent (2002: 12n) e Mirowski (1999: 685n) se inicia em meados da década de 1980 e se intensifica na década seguinte.

24 Acredito que um alerta aqui seja pertinente. Em função deste relato que faço simultaneamente ser um tratamento bastante resumido de uma quantidade enorme de eventos e trazer alguns elementos que não são, entre economistas, amplamente reconhecidos, e nem muito conhecidos, acho que o resultado aqui ficou um pouco "chapado". O que é necessário é ser muito cauteloso com interpretações causais. Se o leitor insistir nas generalizações, é melhor que seja na linha da Guerra ter promovido reconfigurações e novas ênfases de coisas previamente existentes do que ir na linha do "tudo novo". Já se fazia Grande Ciência antes da Segunda Guerra, por exemplo no laboratório de E. O. Lawrence, em Berkeley, Califórnia, e o governo já financiava pesquisa
} 
Entre as características centrais do regime de organização e financiamento de pesquisa que se configurou então nos EUA estão: a presença massiva do estado no planejamento e financiamento de pesquisa e o cultivo do "estilo" de pesquisa da "Grande Ciência".

Em meados do século XX nos EUA, a participação federal no financiamento dos gastos com pesquisa e desenvolvimento passou de cerca de 30\% do total no ano de 1941 para um pico de 66\% no ano de 1964. Ao mesmo tempo, os gastos totais com pesquisa e desenvolvimento também cresceram de forma marcada: eram de $1,4 \%$ do PIB em $1953^{25}$ e atingiram seu auge também no ano de 1964 perfazendo 2,9\% do PIB. ${ }^{26}$ Mirowski e Sent (2002: 16) ressaltam ainda que, além do volume, houve uma dominância estrutural no processo: a exemplo das práticas do Office of Scientific Research and Development (OSRD) durante a guerra, o formato do financiamento se dava por contratos governamentais, distribuídos de acordo com planejamento e política científica, firmados com universidades e com a indústria, mas principalmente esta última. Isto resultou num fortalecimento destas duas instituições, uma vez que os recursos para cientistas individuais eram canalizados através delas. O campo nascente da política científica passou a ser determinante para o direcionamento destes recursos:

Crudely, it became possible for nominal academic scientific stature to be denominated in terms of public intangibles like disciplinary 'credit' or 'eminence,' all the while the money was being allocated according to somewhat different criteria. Even though science was being closely managed by research officers, at first in the wartime OSRD and after in the Office of Naval Research, DARPA (Defense Advanced Research Projects Agency, and other permutations), the Atomic Energy Commission, and elsewhere, the scientists eventually learned to come to terms with any residual sense that there might fester some conflict between their own freedom of inquiry and larger decisions to channel research in certain directions. If the exigencies of national security did not appear sufficiently compelling, the researcher could always take succor from the ethos of 'pure science' within the academy. (Mirowski e Sent, 2002: 21)

também (Galison, 1992: 3). Isso é especialmente verdadeiro no que diz respeito ao conteúdo da ciência, praticamente todas, se não todas, as linhas teóricas e metódicas que ascenderam à dominância no pós-guerra podem ter suas origens traçadas num momento anterior à Guerra. Na economia, como veremos, este é o caso. Foi uma determinada linha pré-existente que ascendeu à dominância, mas transformada, é verdade. Também é bom evitar raciocínios do tipo "com patrocínio militar, logo por causa do patrocínio militar".

${ }^{25}$ Infelizmente não disponho desta informação para o período anterior à Guerra, que seguramente atestaria uma diferença ainda maior.

${ }^{26}$ Os valores são baseados nos dados de Mirowski e Sent (2002: 17) e da National Science Foundation em $<$ http://www.nsf.gov/sbe/srs/s2194/dst1.htm>, acessado em 25/06/04, que é uma das fontes (a principal) que os autores usam. 
Mas não foram apenas o volume e a forma de financiamento que sofreram grandes transformações, a organização da pesquisa, a forma de fazer ciência também. Mais uma vez seguindo paradigmas da Segunda Guerra - o Radiation Laboratory no MIT e o Projeto Manhattan - o aumento "de escala" dos projetos científicos trouxe consigo uma maior burocratização e hierarquização das atividade científica. Mirowski e Sent (2002: 16-18) afirmam que as novas fontes de recursos financeiros levaram o cultivo da Grande Ciência a “escalas antes inimagináveis", onde as atividades eram orquestradas através da hierarquização de grupos interdisciplinares. ${ }^{27}$

Assim, do ponto de vista dos cientistas, estes eventos significaram grandes mudanças. Assinalo dois pontos mais importantes, em primeiro lugar, como foi sugerido acima, a figura de um pesquisador independente foi substituída pela de um membro de um grupo hierarquicamente organizado. Em segundo lugar, houve um processo de profissionalização da atividade de pesquisa e, associado a esta, a instituição de uma carreira científica. ${ }^{28}$ Mirowski e Sent (2002: 14) relatam que, antes da Segunda Guerra, nos EUA, "na maioria dos campos, uma carreira consistindo principalmente de pesquisa simplesmente não era uma opção viável". ${ }^{29} \mathrm{Na}$ medida em que o influxo de recursos aumentou, ser um cientista profissional tornou-se possível. A via de acesso principal se iniciava nos cursos de pós-graduação nas universidades, que sofreram enorme expansão, e seguiam, tipicamente, numa posição de assistente de pesquisa (Mirowski e Sent, 2002: 18).

Outra característica fundamental da Grande Ciência é a sua "resoluta multidisciplinaridade" (Pickering, 1995a: 19-20). ${ }^{30}$ Os profissionais que ingressavam nos

\footnotetext{
${ }^{27}$ Estes fatos são pouco disputados, Dennis (2002) também aponta na direção do aumento de escala, dos elevados custos deste estilo de pesquisa, da sua burocratização, da hierarquização dos grupos e na semelhança dos projetos da Grande Ciência com outras organizações governamentais e industriais. "Alguns países fundaram cidades inteiras para apoiar a pesquisa científica". Do ponto de vista do cientista, o autor aponta para a passagem da posição de um pesquisador independente para a de um membro num grupo hierarquicamente organizado e para o fato de que esta cultura burocrática reformulou a carreira científica no sentido de valorizar a capacidade administrativa e de gerência e a habilidade de obtenção de fundos, além da excelência científica.

${ }_{28}$ Poderia-se argumentar que se tratou de uma reformulação, mas não importa muito, desde que fique claro que o acesso à atividade científica, ao status de cientista, deixou de ter múltiplas vias, por assim dizer, e passou a estar cada vez mais associado a uma carreira institucionalizada (e mais caracterizada e padronizada).

${ }^{29}$ Há que ser lembrado, entretanto, que os EUA não estavam na dianteira da produção científica no período anterior à Guerra.

${ }^{30}$ Mirowski talvez achasse mais apropriado falar de transdisciplinaridade, uma vez que, aparentemente, ele entende o processo como uma disputa por fronteiras disciplinares (principalmente a incursão de físicos a outras searas) antes de uma colaboração ou diálogo entre diferentes disciplinas. Acredito que essa seja efetivamente a versão mais apropriada dos eventos que estamos discutindo.
} 
times envolvidos nas empreitadas da Grande Ciência advinham de diferentes campos, incluindo engenheiros, técnicos e cientistas de diferentes matizes (com predominância e liderança de físicos e matemáticos, todavia). A explicação deste fato é dada pela natureza dos propósitos das próprias empreitadas, que tinham fins eminentemente práticos, a princípio militares e depois industriais e militares. A lógica pragmática da operação ditava as necessidades disciplinares.

Em paralelo a estas reconfigurações houve, como não podia deixar de ser, reformas institucionais e a criação de novos espaços institucionais. Entre as reformas destaca-se a das universidades norte-americanas. Em função da política científica federal foi criada uma situação nas universidades onde o ensino era abertamente promulgado como complementar à pesquisa, e onde as contas da pós-graduação eram em parte custeadas como "despesas gerais" de contratos de pesquisa. Aliado às novas oportunidades de carreira para os novatos, este aporte de recursos proporcionou uma enorme expansão da educação em nível de pósgraduação nos EUA (Mirowski e Sent, 2002: 18).

Mas a acomodação do novo estilo científico se deu também de forma importante através da constituição de novos espaços institucionais, de dois tipos principais. Em primeiro lugar, os think tanks que, na expressão Mirowski e Sent (2002: 18), eram "mais coloquialmente, campi universitários sem alunos", entre os quais o caso paradigmático é o da RAND Corporation. ${ }^{31}$ Outro tipo de instituição criado nesta época foram as organizações de financiamento, como as já referidas OSRD, Office of Naval Research (ONR), Defense Advanced Research Projects Agency (DARPA) e a Atomic Energy Commission (AEC). Por sua vez, estas novas instituições eventualmente estabeleceram controle sobre as universidades na medida em que estas passaram a depender dos "grandes componentes de 'despesas gerais' nos contratos e bolsas" (Pickering, 1995a: 20).

\footnotetext{
${ }^{31}$ Quanto às origens e ao escopo inicial da RAND: "Project RAND was originally the result of two sets of events in 1945: the desire of certain US Air Force figures to maintain a postwar research organization and scientific capacity which they had enjoyed during wartime, by locking in some major expenditure commitments in the medium-term horizon; and the desire of the aircraft industry to maintain a research and development pipeline to retain their lucrative military contracts. ... Contrary to the impression given in some retrospectives, the mandate research had, from the very beginning, been conceptualized more broadly than the mere weapons-system engineering, encompassing the social sciences and abstract mathematical inquiry as well as computational innovation. The paradigm was clearly the operations research team which had become so ubiquitous during the war." (Mirowski, 1999: 704). A RAND Corporation foi fundada, a partir do Projeto, em 1948.
} 
É interessante, neste ponto, selecionar alguns aspectos deste feixe de transformações com que estamos lidando, desta "constelação de trajetórias", na expressão de Andrew Pickering, e olhá-los com maior atenção. Pickering (1995a, 1995b) esboça uma delimitação do que ele chama de regime da Segunda Guerra Mundial. Em linhas gerais, trata-se da confluência entre as empreitadas científica e militar durante a Segunda Guerra e das linhas de desenvolvimento científico, tecnológico e social que emergiram deste encontro e estenderamse ao longo da Guerra Fria e para além dela. Nas palavras do autor:

... I want to examine the construction of an especially significant scientific-military cyborg in World War II and its subsequent evolution (mutation, dispersal, recombination, proliferation, cross-breeding) into our present, as what I call, echoing Foucault, the World War II regime. (Pickering, 1995a: 5)

Claramente, isto é um objeto enorme. Não obstante, o recorte de Pickering é muito interessante para olharmos para alguns desenvolvimentos nas ciências que são particularmente importantes para a nossa discussão, e também para compreendermos melhor a guinada na carreira do próprio Simon que ocorreu logo após a Guerra. ${ }^{32}$

Pickering, entre outros, associa as origens dos desenvolvimentos que estamos discutindo a um profundo acoplamento entre os empreendimentos científico e militar na Segunda Guerra, ${ }^{33}$ e que teve como resultado uma ampla transformação recíproca das práticas militares $^{34}$ e das científicas, como esboçado acima. Um dos pontos focais deste acoplamento foi o MIT que, entre outras coisas, ${ }^{35}$ acomodou o notório Radiation Laboratory, estabelecido pelo National Defense Research Committee (NDRC), com o objetivo de pesquisar e desenvolver tecnologias de radar (Pickering, 1995a: 10, 12n). O "Rad Lab", como ficou conhecido, foi um dos pioneiros na organização da pesquisa na forma de Grande Ciência: ${ }^{36}$

\footnotetext{
32 O recorte é relevante para outros propósitos também, iluminando mudanças na prática militar e a transformação de muitos outros espaços culturais.

${ }^{33}$ A confluência teve início algum tempo antes da entrada dos EUA na Guerra por iniciativa de cientistas civis (Pickering, 1995a: 9-10).

${ }^{34}$ Não acho que caiba discutir aqui detalhes das transformações no âmbito militar, no entanto acredito que não seja difícil ver o papel que passa a ter aí o desenvolvimento científico, incorporado na tecnologia militar, a partir deste momento. A vocação asséptica das práticas de guerra norte-americanas demonstrada nas últimas guerras, mas que já vem desde o Vietnam, está calcada numa vultuosa base tecnocientífica.

${ }^{35}$ Personagens como Vannemar Bush, Philip Morse, Norbert Wiener e Jay Forrester foram professores do instituto.

${ }^{36}$ Inspirado no já mencionado laboratório de Lawrence, mas foi justamente o sucesso do Rad Lab na Guerra que levou com que ele, e não o laboratório de Lawrence, fosse posteriormente utilizado como modelo.
} 
era orientado por missão, hierarquicamente organizado, e composto por times interdisciplinares de cientistas, engenheiros e técnicos. Pickering ressalta ainda o fato de que sua atividade se dava em torno de um objeto, o radar como dispositivo. Eu enfatizaria, e acho que o autor não se oporia, o foco das atividades do laboratório em torno de situaçõesproblema particulares, que a princípio foi a detecção de aeronaves e posteriormente passou a ser a localização de submarinos, no que foram mais bem sucedidos. Na medida em que os primeiros sucessos foram alcançados, segue Pickering, os cientistas começaram a ganhar mais espaço no corpo militar: nos altos escalões foi estabelecido o Joint Committee on New Weapons and Equipment $(\mathrm{JNW})^{37}$ que, diferentemente das instituições anteriores, era mais simétrico no sentido de que o controle da agenda de pesquisa pertencia a ambas as partes; mas, mais importante que isso foi a maior aproximação dos cientistas do dia-a-dia das operações militares, em escalões mais baixos. Esta proximidade, por sua vez, está na origem de um novo estrato conceitual que veio a ser conhecido como pesquisa operacional (Pickering, 1995a: 13). Pesquisa operacional é um rótulo que sempre esteve em disputa, logo não se encontra muito consenso sobre a sua definição. Muitas vezes ele é definido como um conjunto de técnicas, no entanto, o conjunto propriamente dito costuma variar bastante. Entre as típicas encontram-se a programação linear, a teoria do controle, teoria de servomecanismos e/ou de feedback, teoria de sistemas, teoria da probabilidade, programação dinâmica, teoria dos jogos, entre outras. Eventualmente estas técnicas foram agrupadas no que se chamou de "abordagem de sistemas" ou "análise de sistemas". ${ }^{38}$ Elas também foram identificadas, em especial quando de sua divulgação, com a aplicação pura e simples do método científico a problemas de administração. Talvez seja mais produtivo pensar a pesquisa operacional a partir de seus propósitos originais para melhor compreender as diferentes versões em que ela veio a se concretizar:

Operations research was born in Britain and, as its name suggests, had to do initially with the engagement of scientists in the planning and evaluation of military operations, especially as these involved the new technoscientific hardware we have been discussing radar. (Pickering, 1995a: 13) ${ }^{39}$

\footnotetext{
${ }^{37}$ Pickering (1995a: 18) denomina, apropriadamente, estas organizações - o NDRC, o JNW e o OSRD - de instituições de vigilância e controle.

${ }^{38}$ Mirowski (1999: 687-695) dá sua versão da história da pesquisa operacional, bem como algumas das diferentes definições atribuídas ao rótulo. Outra referência a esse respeito é Fortun e Schweber (1993).

39 O próprio Simon tem uma boa definição: "A more understandable and defensible definition of operations research is a sociological one. Operations research is a movement that, emerging out of the military needs of
} 
A pesquisa operacional foi trazida para os EUA no ano de 1942 por uma unidade de combate anti-submarinos da marinha norte-americana, a Antisubmarine Warfare (ASW) Unit (Pickering, 1995a: 13). No interior desta unidade, Philip Morse organizou um grupo de pesquisa operacional (o ASW OR Group) de mais ou menos trinta pessoas, formado principalmente de físicos e matemáticos. A descrição das atividades deste grupo ajuda a formar uma idéia do que se tratava a pesquisa operacional nos EUA então. Pickering (1995a: 15) utiliza-se do testemunho do próprio Philip Morse para tanto. A princípio eles se depararam com um arquivo - "uma sala cheia de relatórios de todas as ações de ou contra submarinos inimigos, reais ou imaginados", resultante da atividade de vigilância sobre operações militares - e o objetivo era fazer uso deste arquivo operacional. "A pesquisa operacional cresceu como disciplina no interior deste arquivo". Eventualmente, o arquivo existente se mostrou insuficiente: faltavam dados importantes e os dados existentes não eram confiáveis. Isto, por sua vez, levou técnicos a campo em busca da informação. A idéia da atividade dos grupos de pesquisa operacional como sendo uma de vigilância interna da atividade militar é importante, e há que ser ressaltada.

Um outro ponto interessante marcado por Pickering a respeito da pesquisa operacional, e que tem sido enfatizado por outros pesquisadores também, é o seu caráter "ciborgue", 40 a pesquisa operacional é uma "ciência ciborgue":

I said above that I think it is useful to describe OR [operations research] as a cyborg science, and now I should explain what that means. The point is simple enough. Unlike the traditional natural sciences that find their ontological foundation in the material world, or the traditional social sciences that speak of the distinctively human (or social), the ontology of OR was the operation: the performance of heterogeneous assemblage of humans and nonhumans, of planes, submarines, radar sets and radar operators, pilots, depth charges, and so on. As a science concerned with the business of fighting wars (and, later, running factories and so on), OR was indifferent to the traditional distinctions between people and things that define both (a form of) modernist common sense and the boundaries between the classic academic disciplines. ... This lumping together of the

World War II, has brought the decision-making problems of management within the range of interests of large number of natural scientists and, particularly, of mathematicians and statisticians." (Simon, 1960: 15, ênfase minha). Naturalmente, a pesquisa operacional não se restringiu ao radar e nem mesmo ao âmbito militar. As operações industriais foram o primeiro campo de expansão no pós-guerra. O próprio Simon participou deste movimento (Holt, Modigliani, Muth e Simon, 1960).

${ }^{40}$ Embora o termo "ciborgue" seja "sonoro" a idéia por trás dele é simples, mas nem por isso menos cheia de implicações. Tal como Pickering o usa, trata-se de algo de desafia as fronteiras tradicionais entre o humano e o não humano. A origem dele é a seguinte: "There is, as it happens, a nice word for the intimate conjunction of the human and nonhuman which, as it also happens, derives from one of the topics I want to explore historically. The word is 'cyborg,' an abbreviation for 'cybernetic organism' and denoting a human/machine actor in which the two parts are constitutively coupled to one another." (Pickering, 1995a: 3) 
human and the nonhuman and the unprincipled working of both sides of the boundary in the name of overall performativity is what I want to point to in naming OR a cyborg science. (Pickering, 1995a: 21-22)

Percebam que a permissividade ontológica da pesquisa operacional opera tanto no sentido de romper as barreiras entre o humano e o não humano quanto no sentido de romper barreiras disciplinares tradicionais. Isso por si só já é esclarecedor, mas eu queria ressaltar também um outro ponto. Como resultado da intersecção entre as atividades científicas e militares na Segunda Guerra, a atividade dos cientistas no interior do esforço militar empregava métodos científicos num registro normativo diferente: as necessidades da operação militar colocavam demandas externas à atividade dos cientistas enquanto tais. ${ }^{41} \mathrm{~A}$ atividade militar, como atividade política, opera numa ética de responsabilidade, e não de convicção. A questão aqui não é se isso deveria ou não ter sido feito, mas simplesmente que ocorreu. Uma das conseqüências deste "conflito de critérios" foi a flexibilização ontológica da ciência, a que Pickering se refere, mas esta não foi a única. A princípio, diante da operação, todas as fronteiras são colocadas em questão. Se a utilização do radar em campo envolvia simultaneamente questões que, do ponto de vista do corpo acadêmico, diziam respeito a diferentes disciplinas e a diferentes esferas do entendimento, e se era um físico a pessoa disponível para tratar destas questões, equipado com as ferramentas teóricas e metódicas de um físico, então ele ia, por necessidade, invadir outros campos. Acontece que os físicos e matemáticos eram "as pessoas disponíveis" e o resultado foi efetivamente uma incursão dos cientistas naturais pelas ciências sociais:

Cyborg sciences like OR and systems dynamics, as already indicated, mark encroachments primarily by natural scientists, engineers, and mathematicians upon the terrain of the traditional social sciences (and not the reverse). And one of the striking features of the World War II regime is the extent to which this encroachment has taken place - not, it has to be said, in the total effacement of the traditional humanist social sciences, but, topologically, in the layering of cyborg sciences over the traditional social sciences, a process that continues today." (Pickering, 1995a: 27-30).

Mas não há nenhum motivo para supor que a pressão exercida por essas demandas acarretasse numa maleabilidade apenas ontológica, a flexibilização dos métodos também era forte candidata, desde que, fique claro, o resultado não fosse comprometido, o desempenho da operação não fosse prejudicado. Previsão é mais importante que descrição. O método

\footnotetext{
${ }^{41}$ Um exemplo curioso da esquizofrenia resultante disso foi a existência de jornais científicos totalmente confidenciais (Mirowski e Sent, 2002: 21).
} 
disponível é um bom método, pois soluções têm de ser alcançadas em tempo hábil. O método simples e padronizado é melhor, e é melhor ainda se houver uma receita, como: identifique as variáveis relevantes, construa uma função objetivo, quantifique as variáveis (mesmo que elas resistam a isso), obtenha estimativas empíricas dos parâmetros relevantes e de como as variáveis afetam o desempenho do sistema tal como medido pela função objetivo e, finalmente, determine a ação pertinente de acordo com a função objetivo e os parâmetros estimados. $^{42}$

Do ponto de vista disciplinar, a queda das barreiras tradicionais estava associada a uma maior tolerância com analogias e metáforas, oriundas, por sua vez, principalmente da física e da matemática. ${ }^{43} \mathrm{O}$ caso de von Neumann é ilustrativo: nos conta Mirowski (1999: 692-693) que ele via a pesquisa operacional como "um vasto campo de analogias matemáticas inexploradas", e tinha estas analogias como os elos conceituais através dos quais a física podia penetrar na teoria social.

Em suma, a pesquisa operacional tinha como importante característica a flexibilização da atividade dos pesquisadores quase em geral: ${ }^{44}$ ontológica, disciplinar, metódica etc; resultante do pragmatismo ${ }^{45}$ exigido pela operação. Por outro lado, o conteúdo da pesquisa, a temática, as questões sobre as quais a pesquisa se debruçaria passaram a ser mais restringidas. ${ }^{46}$ Estas restrições, no entanto, não devem ser pensadas de maneira determinística. Em primeiro lugar, os detalhes da atividade de pesquisa em geral não eram controlados, ao contrário, era praxe dar aos pesquisadores uma liberdade significativa de pesquisa. Em segundo lugar, estas restrições eram frutos de um processo dialógico:

The application of OR was all bound up with struggles over the modalities of funding of research and the ability of the paymasters to dictate the types of research pursued. Indeed, for Vannevar Bush in World War II, OR was an indirect device for physical scientists to

\footnotetext{
${ }^{42}$ Não é difícil encontrar versões da receita na literatura, que variam um pouco mas transmitem a mesma idéia geral. Veja, por exemplo, Mirowski (1999: 692) e Simon (1960: 16-17).

${ }_{43}$ Mirowski coleciona casos deste tipo na economia.

44 "What physicists did have is self-confidence, and this may account for the 'anything goes' characteristics of OR. 'Any approach is legitimate in an operations research study as long as it leads to a better understanding of the problem'. If this argument is right, then populations geneticists, economists, physical chemists in possession of the same tools could and would have done the same thing. And indeed they did." (Fortun e Schweber, 1993: 627)

${ }^{45}$ Uso pragmatismo aqui no sentido comum de "consideração das coisas de um ponto de vista prático".

${ }^{46}$ Pode-se argumentar também que o incremento de recursos e a nova forma de organização da pesquisa em grupos maiores, por outro lado, expandiu a fronteira de possibilidades temáticas. Concordo, mas ainda assim, contra-argumento que o mais importante aqui é o fato de que aquilo que ia ser pesquisado, o conteúdo da pesquisa, passou a ser objeto de maior disputa do que era antes.
} 
wrest control over strategy and tactics away from their less sophisticated military patrons, the better to preserve control over their own military-subsidized research [Zachary, 1997: 160]. Who would be gracious enough to help whom, with what activities and to what ends, was part of the outcome of the process, and not part of the given problem situation. (Mirowski, 1999: 689)

Mirowski (1999: 687), juntamente com alguns outros autores, tenta resgatar nestes eventos a centralidade da pesquisa operacional, o "órfão mal-amado da história da ciência, apesar de alguns autores que estiveram próximos aos eventos terem argumentado que ela 'foi um dos principais traços científicos da guerra'". Segundo ele, o motivo pelo qual a pesquisa operacional se tornou tão importante, que está longe de ser óbvio, não foi por conta de nenhuma descoberta ou inovação técnica particular, mas sim porque um novo espaço social foi criado em torno dela. Foi em torno da pesquisa operacional que a relação entre os cientistas naturais e o estado foi reconfigurada (Mirowski, 1999: 690), foi em torno dela também que se manteve no pós-guerra: a pesquisa operacional era o substrato da relação.

Mirowski enfatiza a distinção entre as variantes "britânica" e "norte-americana" da pesquisa operacional. A variedade é atribuída por ele a fatores culturais (p. 690), em particular à interação entre a pesquisa operacional e as versões locais da teoria econômica. ${ }^{47} \mathrm{Na}$ Inglaterra houve oposição por parte de alguns intelectuais, que fundaram a "Sociedade para a liberdade da ciência", 48 contra a interferência militar na atividade científica, o que talvez possa explicar o menor desenvolvimento da pesquisa operacional naquele país. Já nos EUA, a terra do laissez-faire, a oposição encontrada foi mínima (Mirowski, 1999: 712).

Mesmo concordando com a pertinência da distinção de Mirowski entre as variantes da pesquisa operacional, é importante notar que ela deixa escapar o fato básico de que a variante "norte-americana" da pesquisa operacional era pesquisa operacional feita no contexto da Guerra Fria, e a variante "britânica", no contexto da Segunda Guerra. ${ }^{49}$ E, já que começamos neste argumento, nos fiemos nele e percebamos que as necessidades militares em cada

\footnotetext{
${ }^{47}$ Mirowski (1999: 692) invoca também a grande influência da figura de John von Neumann na configuração da pesquisa operacional nos EUA.

${ }^{48}$ Entre eles: Michael Polanyi, Friedrich von Hayek, John Baker e Arthur Tansley (Mirowski, 1999: 712).

${ }^{49}$ Em linhas gerais, a pesquisa operacional nos EUA durante a Segunda Guerra era feita nos moldes britânicos e se debruçava sobre os mesmos tipos de problema. Lembremos, essa inovação foi "importada" para os EUA apenas em 1942 e, se tomarmos por base a descrição de atividades feita por Morse e citada acima pode-se ver facilmente a semelhança com a pesquisa operacional britânica. Para uma comparação, sugiro olhar a descrição do "Blackett's Circus", o primeiro grupo inglês bem sucedido de pesquisa operacional, em Fortun e Schweber (1993: 600-603). O próprio Mirowski nota que: "the US Air Force think tank RAND, founded in Santa Monica in 1948, became, in the 1950s, the showcase of what OR American-style could acomplish..." (1999: 694).
} 
contexto eram bastante diferentes. Duas linhas centrais através das quais podemos pensar essas diferenças são: o horizonte temporal, curto prazo na Segunda Guerra e longo prazo na Guerra Fria; ${ }^{50}$ e a clareza e definição das situações problema que eram colocadas para os pesquisadores operacionais, bem definidas e vagas, respectivamente.

Esta distinção é congênere ao surgimento da análise de sistemas, como distinta da pesquisa operacional. ${ }^{51} \mathrm{~A}$ análise de sistemas foi concebida na RAND Corporation (Pickering, 1995a: 39) e era vista lá como um desenvolvimento da pesquisa operacional. Fortun e Schweber (1993) situam a passagem da pesquisa operacional para a análise de sistemas em torno das seguintes mudanças: da tática militar para estratégia militar, de decisões localizadas para planejamento. Segundo os autores (p. 602), o propósito central da pesquisa operacional durante a Segunda Guerra era aprimorar o uso das forças e armas militares disponíveis naquele momento. Já o foco da análise de sistemas era orientado para o "planejamento de respostas a necessidades militares e de segurança" baseado em sistemas de armamento projetados e nos respectivos ambientes em que estes sistemas viriam a operar (p. 606). ${ }^{52}$

Em função disso, o conjunto de técnicas sob o guarda-chuva da pesquisa operacional também se ampliou e passou a incluir, então, em particular, a teoria dos jogos, entre outras. A RAND Corporation era também, na década de 1950, e não coincidentemente, a maior instalação para computação com fins científicos do mundo (Mirowski, 1999: 694). É interessante apontar um elo importante nesses eventos: as formas particulares que a Guerra Fria veio porventura a tomar, antes de se concretizarem, eram sonhadas, eram imaginadas nos corredores da RAND, uma instituição quintessencial da Guerra Fria:

RAND, above all, was the place where thermonuclear warfare came closest to reality, where natural and social scientists dreamt of megadeath, where the new rationalities of systems analysis and game theory delineated the ultimate scenarios of Cold War geopolitics. (Pickering, 1995a: 21) ${ }^{53}$

\footnotetext{
50 "In 1946, [the Air Force] contracted with Douglas Aircraft to manage Project RAND (Research and Development) to deal with long term assessments." (Fortun e Schweber, 1993: 605, ênfase minha). Também: "At a more detailed level, in the early 1950s OR evolved at RAND into a more open-ended and futuristic approach that became known as system analysis." (Pickering, 1995b: 6)

${ }_{51}$ Aqui, como em outros lugares na literatura, agrupo ambas sob o mesmo rótulo, mas é interessante notar as diferenças entre elas neste contexto.

${ }_{53}^{5}$ A respeito desta transição na RAND veja também o depoimento de Robert L.Perry em Mirowski (1999: 694).

53 A RAND não era, naturalmente, o único lugar onde isso se dava: "Even before WWII ended, the military began formally consulting the scientists on the future of warfare, and science advisory committees and the like began to engage in exercises of futurology, imagining hi-tech battles between two superpowers. The scientists in
} 
Retornando então a Pickering (1995a, 1995b), cabe notar que a pesquisa operacional não foi a única "ciência ciborgue" a emergir da Segunda Guerra. O autor analisa outras, entre elas a cibernética. Três coisas fazem a cibernética ilustrativa dos eventos em questão. Em primeiro lugar, a cibernética, como a pesquisa operacional, se originou em torno de um objeto específico (nos termos de Pickering), em torno de uma situação-problema, de uma tarefa particular. A cibernética surgiu a partir das considerações de Norbert Wiener de construir um "Previsor Anti-Aeronave", um dispositivo que processaria séries de tempo de observações de trajetórias de vôo visando apontar a artilharia na direção da posição futura prevista da aeronave. O mecanismo de previsão, por sua vez, envolvia um processo de aprendizagem em função da informação sobre o comportamento da aeronave (Pickering, 1995a: 30). Em segundo lugar, o fato do dispositivo nunca ter sido implementado porque Wiener achava que o poder computacional necessário não estava então disponível, demonstra a íntima relação dessas "ciências ciborgue" com os desenvolvimentos do computador. Embora eu não tenha me referido a isso acima, a aplicabilidade prática da própria pesquisa operacional é altamente dependente de capacidade computacional adequada. Em terceiro lugar, as pretensões universalistas que a cibernética veio a adquirir são icônicas: ${ }^{.5}$

Cybernetics then, took computer-controlled gun control and layered it in an ontologically indiscriminate fashion across the academic board - the world, understood cybernetically, was a world of goal-oriented feedback systems with learning. It is interesting that cybernetics even trumped the servomechanisms line of feedback thought by turning itself into a universal metaphysics, a Theory of Everything, a TOE, as today's physicists and cosmologists use the term - a cyborg metaphysics, with no respect for traditional human and nonhuman boundaries, as an umbrella for the proliferation of individual cyborg sciences it claimed to embrace. (Pickering, 1995a: 31)

As ambições não eram especialmente menores no caso da pesquisa operacional (Mirowski, 1999: 691). Uma expressão de Mirowski (1999: 685) resume bem os elementos em jogo: trata-se de "programas de pesquisa interdisciplinares inspirados no paradigma de

this way helped the military and politicians (and the public) to dream military aspects of the Cold War. ... Natural and social scientists and mathematicians also played a role in imagining the military aspects of the Cold War beyond hardware. At the RAND Corporation in Santa Monica, for instance, the tactics and strategy of superpower conflict were conceptualised and thought through in detail, thus specifying the contours of the Cold War itself. Game theory was important here, especially in conceptualising thermonuclear exchanges, with mathematicians, economists and social scientists working together to construct cost-benefit matrices representing the options of the antagonists." (Pickering, 1995b: 5-6). A implicação disso, é claro, é que os desenvolvimentos da atividade científica que viemos discutindo não foram apenas forjados num quadro fixo e exógeno da Guerra Fria, mas foram também parte importante da construção desse quadro.

${ }^{54}$ A esse respeito veja Bowker (1993) e Rosenblueth, Wiener e Bigelow (1943). 
'comando-controle-comunicação-informação' da doutrina militar e o advento do computador". Mas, caracterizado algo do conteúdo e do contexto dessas "ciências ciborgue", é momento de começarmos a retomar um pouco nosso foco.

\subsubsection{Pesquisa operacional e economia}

Com poucas exceções, a literatura que trata das mudanças nas práticas científicas no pós-guerra nos EUA tem seu foco nas ciências naturais, e é apenas neste escopo que tais mudanças estão relativamente bem estabelecidas. Para outras áreas estas questões são mais controversas e ainda estão começando a ser discutidas. Mirowski (1999) ${ }^{55}$ e Hands e Mirowski (1998a, 1998b) exploram as inter-relações entre esta história que viemos discutindo e a da economia, à luz da literatura recente.

Mirowski estabelece vínculos significativos entre os eventos que viemos discutindo e a história do pensamento econômico na mesma época ao traçar "algumas das maneiras em que as exigências da guerra reuniram alguns físicos e alguns economistas sob o patrocínio e apoio dos militares, produzindo amplas conseqüências não intencionais para a profissão da economia no pós-guerra" (1999: 687). Mas para situar este argumento de Mirowski, primeiro será necessário que nos voltemos para algumas questões internas à história do pensamento econômico, mais especificamente, trataremos da teoria neoclássica da demanda. ${ }^{56}$

Hands e Mirowski (1998a, 1998b) documentam um impasse enfrentado na empreitada conjunta de Harold Hotelling e Henry Schultz na década de 1930 para encontrar fundamentos mais apropriados para a lei da demanda. ${ }^{57}$ Em linhas gerais, os contornos do impasse, tais como descritos por Hands e Mirowski, eram os seguintes. Ambos, Hotelling e Schultz, entendiam que a tradição marshalliana não provia um fundamento científico adequado para a teoria da demanda, em particular porque não reconhecia a contumaz interdependência entre as

\footnotetext{
${ }^{55}$ Mirowski publicou em 2001 um livro sobre este assunto, Machine dreams: Economics becomes a cyborg science, ao qual infelizmente não tive acesso a tempo de incorporá-lo aqui.

${ }^{56}$ Exploro aqui a história da teoria da demanda para que tenhamos a dimensão das implicações dos eventos que viemos discutindo acima, para inserir a história do pensamento econômico num contexto mais amplo.

57 Este impasse, para os autores, parece particularmente importante: “... it does seem to both of us that the Hotelling-Schultz encounter is one of those pivotal events around which the entire structure of neoclassical demand theory pirouetted, wobbled, but then miraculously recovered its balance." (Hands e Mirowski, 1998a: 326)
} 
funções de demanda na esfera do mercado, sustentavam que elas estavam "funcionalmente interligadas por ajustamentos racionais a outros preços, à renda, e também a vários acidentes" (p. 345). Estavam preocupados em fundamentar a teoria da demanda também porque entendiam que isto permitiria à teoria tratar algumas das questões práticas então em pauta lembrem-se, trata-se do momento da Grande Depressão. A idéia era olhar "atrás" da lei da demanda, e isto significava para ambos assentá-la sobre uma base de comportamento individual maximizador. ${ }^{58} \mathrm{O}$ que Hotelling e Schultz procuravam era uma teoria geral da constituição da função de demanda, de maneira a esclarecer o caráter e a dimensão das interdependências. Ambos voltaram-se também para os mesmos autores para fornecer-lhes o quadro matemático de que necessitavam: Walras, Pareto e Edgeworth (Hands e Mirowski, 1998a: 345).

Hotelling propôs uma revisão da teoria da demanda baseada num modelo, alcunhado de "modelo de potencial de preços", onde "empreendedores" compravam bens para depois vendê-los. Por este motivo, o problema do empreendedor de Hotelling era um de maximização irrestrita (p. 329). A diferença, portanto, residia no tratamento da renda, no modelo a renda não era fixada independentemente, mas determinada pelo equilíbrio resultante. O modelo gerava implicações testáveis: algumas condições de simetria, ou de “integrabilidade". Os testes do modelo de Hotelling realizados por Schultz não foram nada satisfatórios. Quando Hotelling e Schultz tomaram conhecimento das condições de simetria resultantes da decomposição de Slutsky, Schultz testou ambos os modelos como hipóteses rivais, mas avaliou que as condições exigidas pelos dois modelos pareciam conflitar com os dados. ${ }^{59}$ Os testes basicamente consistiam em saber se havia possibilidade das funções de demanda encontradas no mercado terem sido geradas por um comportamento análogo àquele

\footnotetext{
${ }^{58}$ Eles compartilhavam mais coisas que isso, no entanto: "Clearly their primary concern was neoclassical price theory, but dominating even that theme was their shared appreciation for an understanding of science which overrode their substantial differences. Both passionately believed that science was transparently mathematical, that it was firmly based upon the collection and statistical processing of empirical data, and that physics was the embodiment of the success of the scientific method." (Hands e Mirowski, 1998a: 345)

${ }^{59}$ Schultz, por sua vez, reinterpretou o modelo de Hotelling como um caso particular do modelo de Slutsky (de maximização sujeita à restrição orçamentária) acrescido da hipótese da independência da utilidade marginal do dinheiro (o coeficiente de Lagrange) com relação aos preços (o que ocorre no caso de preferências homotéticas). Hands e Mirowski (1998a: 333) apontam, com razão, que os modelos não são equivalentes, mas que geravam a mesma implicação operacional: que as elasticidades-preço cruzadas da demanda sejam iguais para cada par de bens (no modelo de Hotelling), ou, no caso do modelo de Slutsky, que a hoje chamada de matriz de Slutsky, a matriz dos efeitos substituição, seja simétrica. Sob a hipótese de homoteticidade das preferências, as condições
} 
pressuposto pelo modelo, ou seja, se aquelas poderiam ser as "leis por trás da lei da demanda". Hands e Mirowski (1998a) acompanham de perto, a partir das publicações e da correspondência entre os dois, as persistentes e malogradas tentativas do duo de contornar os problemas empíricos encontrados. ${ }^{60}$ Neste momento, do ponto de vista de Hotelling, seu modelo e o de Slutsky continuavam como explicações rivais da lei da demanda que levavam em conta as interdependências no mercado: seus (in)sucessos empíricos eram equiparáveis, e Hotelling via em seu modelo algumas vantagens teóricas, em particular nas implicações menos ambíguas para medidas de bem-estar social (1998a: 364-365). Hands e Mirowski sugerem que a Grande Depressão e as condições econômicas gerais ajudam a entender os desenvolvimentos da teoria neoclássica da demanda nesta encruzilhada. Em particular, é importante perceber que, ao contrário do modelo de Hotelling, a versão de Slutsky podia ser compatibilizada com a estrutura teórica (macroeconômica) keynesiana:

Since income was broken out as a separate magnitude in the Slutsky equation, one could equally maintain that Slutsky-based demand functions were the ideal scientific microfoundations for and income-driven Keynesian macroeconomics... (Hands e Mirowski, 1998a: 366)

Uma das teses de Hands e Mirowski (1998a, 1998b) é a de que a ortodoxia americana do pós-guerra não é um corpo teórico homogêneo. Mais do que isso, os autores mapeiam a heterogeneidade da ortodoxia norte-americana nas reações ao impasse encontrado por Hotelling e Schultz na década de 1930 que, do ponto de vista do embate entre os modelos de Hotelling e Slutsky, era um de como tratar a renda e o efeito renda na teoria e, do ponto de vista do projeto de ambos os modelos de fundamentar a lei da demanda numa base walrasiana, o problema eram as dificuldades empíricas encontradas pelos dois modelos. Duas vertentes ortodoxas distintas aderiram ao modelo de Slutsky, uma sediada no MIT e outra na Comissão Cowles, embora nunca tenham superado o embaraço empírico associado a ele. Uma terceira preferiu abandonar a questão da interdependência, desistindo de encontrar as leis da lei, e retornar à linha marshalliana, em Chicago. Os autores afirmam que esta é uma característica essencial para a compreensão da heterogeneidade no interior da ortodoxia. Os traços característicos de cada uma das três escolas podem ser organizados e melhor

são equivalentes, caso contrário, as do modelo de Hotelling são mais restritivas. Mas não entrarei nos detalhes de nenhum dos modelos.

${ }^{60}$ Nem Hotelling nem Schultz considerava que seu projeto havia sido bem sucedido (Hands e Mirowski, 1998b: 264-265). 
compreendidos pelos seus tratamentos particulares das condições de simetria e da restrição orçamentária na teoria neoclássica da demanda (Hands e Mirowski, 1998a: 373-374).

Indo ainda mais longe, os autores apontam para o fato de que, se antes da Segunda Guerra o pluralismo de abordagens não permitia atribuir a nenhuma delas a dominância, aquela que viria a se constituir como hegemônica no pós-guerra, a orientação neoclássica, atravessava naquele momento imediatamente anterior à Guerra um período de crise. ${ }^{61} \mathrm{E}$ um dos motivos pelo qual a resolução destas questões se tornou tão cara à ortodoxia norteamericana, argumentam Hands e Mirowski, é o fato de que Hotelling e Schultz e suas preocupações constituíam um "ponto de passagem obrigatório" para qualquer economista matemático naquele momento:

Many of the major streams of neoclassical thought about the nature of demand converged with alacrity upon these two men, and out of their struggle with these issues was conceived the three major skeins of the 1960s American neoclassical orthodoxy: the MIT revealed preference doctrine, the Chicago Marshallian variant, and the Cowles general equilibrium approach. (Hands e Mirowski, 1998a: 326)

De fato, muitos dos maiores expoentes neoclássicos do pós-guerra tiveram relações elaboradas com pelo menos um deles: Kenneth Arrow, Milton Friedman, Paul Samuelson, George Stigler entre outros (Mirowski, 1999: 697; Hands e Mirowski, 1998a: 326, 1998b). Este é um ponto importante, pois é aqui que as histórias se ligam. Segundo Mirowski (1999: 697), as diferentes respostas ao impasse de Hotelling e Schultz - e, portanto, as distintas vertentes neoclássicas do pós-guerra - tiveram a ver com as reações de indivíduos chave às suas experiências com a pesquisa operacional durante a Guerra e com suas relações continuadas com ela no pós-guerra, o "constructo da pesquisa operacional e o patrocínio militar que o acompanhava foram cruciais na definição da forma da teoria econômica do pósguerra nos EUA" (Mirowski, 1999: 698). O autor detalha o caso para duas das referidas vertentes: a variante marshalliana de Chicago e a abordagem de equilíbrio geral da Cowles, mapeando as respectivas influências no Statistical Research Group (SRG) e na RAND Corporation.

\footnotetext{
${ }^{61}$ Mas que não era exatamente só uma crise do projeto pessoal dos dois: "There is some evidence that the crisis was not merely localized around these two individuals: for instance, a case can be made that the Cowles Commission was floundering in the years 1937-8, and perhaps through 1942. The Chicago Economics Department was also in trouble in the early 1940s." (Hands e Mirowski, 1998a: 371)
} 
O SRG em Columbia foi criado em 1942, ligado ao Applied Mathematics Pannel (AMP), por decisão de Warren Weaver, e sob a liderança de um de nossos personagens: Harold Hotelling. ${ }^{62}$ Foram trazidos para o grupo: W. Allen Wallis, Julian Bigelow, Leonard Savage, Milton Friedman e George Stigler. Tirando Bigelow e incluindo Gary Becker, que foi aluno de Friedman, temos o núcleo da Escola de Chicago de economia. Mas, além do próprio grupo, Mirowski identifica algumas das marcas registradas da Escola com as práticas de pesquisa operacional:

The Chicago School of economics, with its rough-and-ready pragmatism about the nature of the underlying objective functions, was little more than Blackett's OR imported back into economics. Consider the standard practices of Blackett's Circus: look for 'quantifiable' variables, even when the problem resists quantification. Then posit a simple 'as if' objective function, and collect data on the supposed partial derivatives of the function. Marvel at the extent to which 'large bodies of men and equipment behave in an astonishingly regular manner'. Treat the set of designated causes as comprising a closed system, invoking ceteris paribus if necessary to avoid the fact that the list cannot be exhaustive. Use statistics to paper over the uncertainties, ambiguities and unknowns of the problem as portrayed, both for the economist and the agent, and to churn out predictions for the client. Keep psychology out of it. Remember that OR is just 'social science done in collaboration with and on behalf of executives'... (Mirowski, 1999: 701)

Mesmo sem ceder à afirmação forte de que a Escola de Chicago de economia era "pouco mais que a pesquisa operacional de Blackett" cabe reforçar que, no mínimo, algo (importante) dela era. Lembremos que, segundo o argumento de Hands e Mirowski (1998a, 1998b), uma importante característica distintiva da variante marshalliana de Chicago era a sua posição com relação ao efeito renda, herdado do impasse de Hotelling e Schultz. Em particular, a resposta da escola de Chicago consistia em afirmar que, para fins de economia política, os efeitos renda podem ser desconsiderados, porque a parcela "permanente" do efeito é pequena e a "transitória" tende a se auto-compensar na média, embora não houvesse maneira de separá-las na prática. Assim, para efeitos práticos, a análise das funções demanda como exercícios de equilíbrio parcial pôde ser preservada (Mirowski, 1999: 701). O próprio Friedman reconhece que essa decomposição do efeito renda foi feita com base em uma

\footnotetext{
${ }^{62}$ As atividades do grupo não diferiam da versão "quente" da pesquisa operacional que já descrevi: "The tasks initially assigned to the SRG bore a close resemblance to those generally carried out by British OR units, augmented by the gun-aiming concerns of Weaver's fire-control panel. They included evaluating gun effectiveness in air dogfights, comparing bomb sights, calculating pursuit curves for homing torpedoes, estimating probability of aircraft damage with random flak versus Merle Tuve's newly-developed proximity fuse, and gauging B-29 vulnerability." (Mirowski, 1999: 699)
} 
analogia direta com seu trabalho no SRG sobre o detonador de proximidade. ${ }^{63}$ Mirowski aponta ainda para o estilo interdisciplinar e presunçoso de Chicago, entre outras coisas, como influência da pesquisa operacional (p. 702-703). Assim, o padrão de ciência, o estilo de pesquisa e modelos específicos de Chicago foram influenciados pelas experiências de guerra de alguns de seus líderes e pelo contato destes com a pesquisa operacional.

A Comissão Cowles, por sua vez, foi introduzida à pesquisa operacional por intermédio da RAND, que "foi a principal influência intelectual sobre a Comissão Cowles nos anos de 1950, o que é o mesmo que dizer que a RAND foi a inspiração para muito da formalização matemática avançada da ortodoxia neoclássica no período imediatamente após a Guerra" (Mirowski, 1999: 703-704). O caso da teoria dos jogos, que não excitou a comunidade dos economistas desde o princípio, mas que teve seu apoio sustentado na RAND, entre outras coisas pela própria influência de John von Neumann na instituição, é um exemplo óbvio da importância da corporação para teoria econômica. A RAND foi fonte de muitas das idéias que viriam a ser exploradas mais tarde:

These ideas, from Nash equilibria of non-cooperative games to 'psychological' experimental protocols, from 'scratchpad wars' to computer simulations, from dynamic programming to evolutionary dynamics, from 'rational decision theory' to automata playing games, now constitute the orthodoxy of the fin-de-siècle American economics profession; in each case, RAND was there first. (Mirowski, 1999: 706) ${ }^{64}$

A Comissão Cowles foi fundada no ano de 1932 e, segundo Hands e Mirowski (1998a: 374), o momento originário da "escola" pode ser dividido em dois períodos, que correspondem aproximadamente às diretorias de pesquisa de Jacob Marschak, de 1943 a 48, e de Tjalling Koopmans, de 1948 a 54. A diretoria de Marschak ficou mais conhecida pelo seu programa econométrico: o problema da identificação, equações estruturais simultâneas, a

\footnotetext{
63 "One article of mine that in a very important sense grew almost entirely out of the work of the SRG was the article which I wrote in 1953 on 'Choice, Chance and the Personal Distribution of Income' [Friedman, 1953]. It traced directly to our work in the proximity fuze. One element in the work on the proximity fuze was the attempt to approximate the time distribution of bursts. The proximity fuze had two impulses, one forward and one backward. As a result there were generally two modes in the distribution. We treated this as a sum of two separate distributions.... The resemblance of those distributions of bursts to income distributions got me started to thinking about whether the same method could not be used to describe income distributions, and that result is directly and immediately reflected in the article I referred to." (Milton Friedman apud Mirowski, 1999: 702)

${ }^{64} \mathrm{E}$ também: "Systems analysis, artificial intelligence and the discipline of software engineering were all started there; game theory found its life-support system there in those all-too-critical early years; even 'evolutionary economics' found its inspiration there. RAND itself was consciously constructed to break down disciplinary barriers between the natural and the social sciences, and to spread the gospel of complexity, after the example promulgated by Warren Weaver.” (Mirowski, 1999: 704)
} 
correção dos vieses de estimação, teste de hipótese de Neyman-Pearson, e a gênese da macroeconometria keynesiana (Hands e Mirowski, 1998a: 374, 1998b: 276). Hands e Mirowski argumentam que, no entanto, o programa econométrico era subordinado a objetivos mais gerais, dos quais Hotelling e Schultz eram, uma vez mais, a origem. Sob a batuta de Marschak a Comissão Cowles era tida, em primeiro lugar, como uma partidária da teoria de equilíbrio geral walrasiana, e da equação de Slutsky em particular, e suas "outras formidáveis realizações eram normalmente vistas como subordinadas a este propósito mais amplo" (Hands e Mirowski, 1998b: 276).

No final da década de 1940 as coisas começaram a mudar. Segundo Hands e Mirowski (1998a: 375), o declínio do foco econométrico teve como principal motivo a avaliação de muitos dos próprios membros da Cowles de que o programa "havia falhado em sua promessa original": as novas técnicas de estimação de equações simultâneas não resultavam em coeficientes muito diferentes das técnicas mais simples de mínimos quadrados ordinários, "e pior", a capacidade de previsão dos modelos era muito baixa. Durante a diretoria de Koopmans o centro das atividades pode ser melhor exemplificado pelo trabalho de Kenneth Arrow e Gerard Debreu na teoria do equilíbrio geral (p. 375). A "resolução" dos impasses se deu pelo rigor na forma, pelo distanciamento da empiria, e ainda pela reconceptualização do agente econômico neoclássico como um "econometrista em miniatura", como um processador de informações auto-contido, pela entidade virtual de um agente que se comportaria como o modelo se fosse completamente racional e onisciente:

In brief, given the failure of the Schultz program via Marschak, retention of the basic program would require that the scientific credentials of neoclassical economics be validated by some other authority. The redirection of the Cowles Commission is poignantly captured by the revision of its motto in 1952 from the previous "Science Is Measurement" to "Theory and Measurement." Actually, "Theory and Rigor and More Theory" would have been more accurate, since the commission wholeheartedly embraced the Bourbakist program of axiomatization and formalization in order to bolster the flagging fortunes of the Walrasian program. In caricature, if a concerted program of statistical testing could not place demand theory on firm footing, then perhaps a comprehensive axiomatization of Walrasian general-equilibrium theory could effectively do the job. (Hands e Mirowski, 1998b: 280-281)

No começo da década de 1940 a Cowles enfrentava uma situação delicada (Mirowski, 1999: 707). Por um lado, o programa de pesquisa regido por Marschak, como comentamos, não vinha produzindo os resultados esperados; por outro, seu suporte financeiro estava cambaleando. A comissão dependia quase que totalmente de duas fontes de financiamento, a 
Fundação Rockefeller e a família de Alfred Cowles. Naquele momento, ambas as fontes estavam periclitando. A passagem do bastão de Marschak para Koopmans, e a resolução do problema financeiro, esteve associada entrada de um novo patrocinador, a RAND Corporation, intermediada por von Neumann. ${ }^{65}$

A mudança do programa de pesquisa da Cowles, argumenta Mirowski, coincidiu quase que exatamente com este evento, e esteve diretamente relacionada a ele. Como é amplamente reconhecido pelos economistas, não há almoço grátis: “a questão de quem paga nunca é separável do tipo de trabalho que é pago" (1999: 707), o caso da Cowles não foi exceção. O novo programa de pesquisa aceito pela Cowles, afirma Mirowski (1999: 708), foi ditado pela versão de von Neumann da pesquisa operacional, "ou pelo menos tanto dela quanto eles achavam que podiam reconciliar" com seus inabaláveis compromissos com a teoria de equilíbrio geral walrasiana. $\mathrm{O}$ aporte de fundos ressuscitou as perspectivas do projeto neoclássico.

Assim, no caso da Cowles Commission, o contato com a pesquisa operacional, e com a estrutura associada a ela, no imediato pós-guerra, esteve ligado a uma ampla mudança na agenda de pesquisa do grupo e nas técnicas empregadas. Além disso, a associação fortuita, e a conseqüente injeção de recursos, foi utilizada como recurso na sustentação do programa neoclássico, embora reconfigurado, nessa vertente.

Em resumo, as respostas para as perguntas: “O que pesquisar?”, "Para que pesquisar?”, "Para quem pesquisar?", “Como pesquisar?”, foram todas revistas no processo. O que era entendido por "ciência" também mudou:

War disrupted the careers of most of our protagonists ... but it did more than that. First, it provided a five-year hiatus right at the point where the death of Schultz and the failure of the Schultz-Hotelling project had helped raise the question: 'Whither mathematical economics?'... But, second, the war had a more profound impact upon the next generation of social scientists in terms of the way they understood 'science.' ... [the individuals we are most concerned] were engaged in research that might normally be the province of engineers or meteorologists or physical statisticians alongside physicists who were also temporarily engaged in 'applied' work; sometimes this new form of collaboration gave

\footnotetext{
65 "In July 1948, the devolution of the research directorship from Marschak to Koopmans marked the escape route from this intolerable bind, by the cultivation of a new patron and a new research programme. That patron was RAND; the matchmaker was von Neumann. Koopmans had become acquainted with von Neumann during a wartime interlude at Princeton, just after his own escape from Europe in 1940. Koopmans' ties to von Neumann now began to pay. Like other sciences blessed by the postwar largesse, the Cowles budget ballooned from a mere $\$ 4850$ in receipts in 1944 to $\$ 153,000$ a year by 1951 , with RAND covering 32\% of the total, and the Office of Naval research covering an additional 24\%." (Mirowski, 1999: 707-708).
} 
rise to a new hybrid called 'operations research.' The importance of this phenomenon for our present narrative is that it fostered the enhanced importation of newer notions of science into the economics profession, as well as blurring the conceptual boundaries between persons and things. (Hands e Mirowski, 1998a: 371-372)

Antes de finalizar este item, convém fazer ainda um par de comentários. Em primeiro lugar, cabe reforçar a ressalva feita a princípio. Ressaltar os eventos associados à Segunda Guerra, e em particular a pesquisa operacional, como fatores intervenientes nos desenvolvimentos das ciências não equivale a sustentar a tese de que a atividade científica é externamente determinada em qualquer sentido estrito. Não questiono o fato de que o embate de idéias propriamente dito se constitui enquanto tal. ${ }^{66} \mathrm{Em}$ segundo lugar, após essa dispersa reconstituição histórica, um apanhado geral pode ajudar a organizar as idéias. Tentei recortar os eventos através de três planos distintos. O primeiro, e mais geral, é o que Andrew Pickering chamou de regime da Segunda Guerra Mundial. Trata-se de um plano de transformações culturais bastante amplo, que vai do cinema ao chão de fábrica, das práticas científicas e militares à globalização. Não penetramos muito fundo aí, mas esse é o quadro geral. O segundo plano, foi o recorte, a partir desta referência, da transformação da prática científica por meio da associação com os militares. Aí surgiram os temas da Grande Ciência, das ciências ciborgue e da pesquisa operacional e suas características. O terceiro plano foi traçado na fronteira entre a história pesquisa operacional e a história do pensamento econômico no interior daquele contexto mais geral. É importante que fique claro que todos os três planos se inter-relacionam e se influenciam mutuamente. Um quarto plano, ainda, é o biográfico, o que nos traz de volta ao nosso protagonista.

\footnotetext{
${ }^{66}$ Assino embaixo de Hands e Mirowski (1998a: 327) neste ponto: "What happened in economics was as much the product of the Great Depression and the Second World War or contemporary upheavals in physics as it was or perspicacious farsighted theorists and empiricists subjecting their ideas to stringent tests; nothing less in the way of narrative accounts will do... Nevertheless, the absence of any clean 'scientific method' does not imply that randomness, whimsy of bald power plays were the predominant order of the day."
} 


\subsubsection{Simon e a RAND ${ }^{67}$}

Quando, no início da guerra, ficou claro que Simon não iria para a ativa, ele conseguiu um lugar no Illinois Institute of Technology, na cadeira de ciência política, retornado de Berkeley para Chicago, no ano de 1942. Mais para o final do conflito, por sugestão de William Cooper, ${ }^{68}$ que fora seu colega de faculdade, ele começou a acompanhar os seminários semanais de pesquisa em economia da Comissão Cowles, que estava então sediada em Chicago (Simon, 1996a: 93, 101). A Cowles tinha então um time de (futuras?) estrelas: ${ }^{69}$ Jacob Marschak, Tjalling Koopmans, Oskar Lange, Kenneth Arrow, Larry Klein, Leo Hurwicz, Don Patinkin, Gerard Debreu e outros. Entre os visitantes usais estavam Franco Modigliani e Andy Papandreou, e entre os eventuais George Stigler, Milton Friedman, Ragnar Frisch e Trygve Haavelmo (Simon, 1996a: 101-102).

Mais tarde, Simon se tornou também um consultor para a Comissão, e depois, através de seus laços na Cowles, um consultor para a RAND Corporation, a partir de 1952 (Sent, 2000: 383, Simon, 1996a: 116, 131). Os laços com a RAND rapidamente se estreitaram:

From the spring of 1952, I was a frequent consultant at RAND, particularly in connection with the Systems Research Laboratory which was created that year, and then, after 1955, with the Computer Science Department. I spent the entire 1960-1961 year on leave of absence at RAND. (Simon, 1996a: 131, veja também p. 164)

\footnotetext{
${ }^{67}$ Argumento aqui em favor de uma descontinuidade na carreira de Simon. Augier (2001: 309-310) discute a carreira de Simon focando em suas continuidades que, em sua análise, giram em torno do conceito de racionalidade restrita e de sua teoria comportamental. Todavia, isso é feito às custas da ausência uma adequada apreciação da diferença entre tomada de decisão e solução de problemas. As concepções de Simon sobre a tomada de decisão e sobre a solução de problemas estão intimamente ligadas em sua obra, é verdade, mas é melhor pensar as primeiras como tendo servido de base para as últimas, como faz Sent (2000: 388-389n). O próprio Simon, em algumas instâncias, se descreve como "um completo monomaníaco", "obcecado com a tomada de decisão humana e com processos de solução de problemas no indivíduo, em interações entre indivíduos em organizações governamentais e de negócios e na economia" (2001: 501). A diferença reside, creio eu, na proximidade com que olhamos. Entendo que, no grau de detalhe pertinente a este estudo, o que se sugere é a ruptura. Ademais, como veremos, também o próprio Simon a testemunha.

68 "Bill" foi um amigo de Simon que esteve presente em alguns momentos chave da vida de Simon. Este foi um deles. Foi ele também quem convidou Simon para participar da criação da Graduate School of Industrial Administration no Carnegie Institute of Technology no ano de 1949. Simon passaria todo o restante de sua carreira acadêmica nesta instituição (embora mais tarde o Carnegie Tech tenha se fundido com o Mellon Institute para formar a Carnegie-Mellon University, no ano de 1967). Mas não menos importante, Cooper foi quem arranjou o primeiro encontro de Simon com Dorothea.

69 "The list, you will note, includes no less than nine future nobelists." (Simon, 1996a: 102)
} 
Simon chama o Systems Research Laboratory de um projeto "grandioso".70 Foi concebido por John Kennedy, William Biel, Robert Chapman e Allen Newell e tinha como objetivo estudar em laboratório o comportamento de uma estação de defesa aérea. $\mathrm{O}$ laboratório simulava uma estação de aviso antiaéreo inteira, com aproximadamente cinqüenta homens. Durante três anos eles conduziram experimentos no laboratório, onde toda a comunicação entre os sujeitos era gravada (Simon, 1996a: 167-168). ${ }^{71}$

O contato de Simon com a RAND teve grandes conseqüências para a sua carreira como cientista. $^{72}$ Primeiro, as frustração das tentativas de análise no SRL viriam a fornecer o mote para a principal agenda de pesquisa de Simon daí por diante. Segundo, lá Simon conheceu Allen Newell, que viria a ser o seu principal colaborador nesta nova agenda, eles trabalharam juntos e intensamente durante diversos anos. Em terceiro lugar, a RAND forneceu à dupla a saída para seu impasse. Lá eles tiveram acesso a computadores, que lhes deram, a um só tempo, os meios e a linguagem para formalizar sua teoria. E lá também eles conseguiram os fundos necessários para conduzir suas pesquisas, já que recursos computacionais naquela época eram algo bastante caro. O próprio Simon testemunha o papel da RAND neste processo ao atribuir a "[seu] trabalho no SRL na RAND e o contato que teve lá com computadores" a "virada completamente nova" que sua vida tomou nesta época (1996a: 198). Assim, cabe olharmos cada um destes pontos com mais cuidado.

Allen Newell se formou em física na Universidade de Stanford, depois iniciou uma pósgraduação no Departamento de Matemática, mas a abandonou após um ano ao convencer-se de que seus interesses estavam na matemática aplicada, e não na pura. Daí ele ingressou na RAND, onde Simon o encontrou:

When I first met Al at RAND in 1952, he was twenty-five years old, and fully qualified for tenure at any university - full of imagination and technique, which is what it takes to make a scientist. ...

\footnotetext{
${ }^{70}$ E adiante: “... a grandiose project, if there ever was one outside physics and space science.” (Simon, 1996a: 200)

${ }^{71}$ Os dados obtidos eram bastante detalhados: "The SRL experiments provided the most microscopic data one could want on how radar operators and air controllers made their decisions." (Simon, 1996a: 168). As tentativas de descrição formal do processo foram em geral frustradas, mas mais tarde o laboratório foi convertido num centro de treinamento da Força Aérea norte-americana.

${ }^{72}$ As mudanças estão bem documentadas em Sent (2000), assim, limitar-me-ei a apresentar os aspectos delas que acho mais relevantes para o nosso assunto aqui.
} 
If imagination and technique make a scientist, we must also add dollars. I learned many things in the postdoctoral training I took with Al, few more important than how to position the decimal point in a research proposal. (Simon, 1996a: 199-200) ${ }^{73}$

A afinidade de visão entre os dois foi logo notada por ambos, e aparentemente se assentava em pelo menos dois pontos, a tendência para uso da matemática em seus trabalhos e a idéia da mente como um sistema que processa símbolos (Simon, 1996a: 168). O computador deu-lhes o meio (a simulação no computador) e a linguagem (os programas) necessários para levar essa última idéia adiante. ${ }^{74}$

Sent (2000: 397) afirma que a RAND teve um papel vital no fomento do programa de pesquisa de Newell e Simon em inteligência artificial, a despeito de alguma oposição que vieram a encontrar na instituição. Eu desconheço qualquer dado mais concreto a respeito da dimensão do suporte financeiro da RAND para eles. Mas o SRL seguramente tinha um orçamento elevado. E a estrutura da RAND era de fato fundamental para eles: como apontei acima, ela tinha a maior estrutura computacional para fins científicos do mundo na época. Mesmo sediados em Pittsburgh, seus programas eram rodados nos computadores em Santa Monica, na RAND (Simon, 1996a: 203). Em 1995, Newell se mudou para Pittsburgh para trabalhar com Simon na GSIA, mas se manteve como funcionário da RAND (p. 203). Simon manteve também seus vínculos como consultor da RAND. ${ }^{75}$

Os laços com a Cowles e com a RAND também forneceram a Simon um outro elemento crucial para sua pesquisa: exposição e visibilidade. Como ele próprio coloca, "[sua] carreira acadêmica havia começado num remanso acadêmico: administração pública", mas "em poucos anos [ele] estava estrategicamente situado nas ciências sociais, sendo notado por e influenciando praticamente todas elas" (1996a: 114).

But to return to the subject of gravitation, my first important movement from the recesses of outer space toward the sun was my association with the Cowles Commission, which was at the very center of the new postwar developments in mathematical economics and

\footnotetext{
${ }^{73}$ A esse respeito: "Al learned about research funding through his early association with physicists, and it is a lesson that the behavioral scientists still need to study with him." (Simon, 1996a: 200)

74 "Upon observing Newell's simulated radar screen, Simon was introduced to the idea that computers could be employed for something other than producing numbers. Specifically, Simon interpreted the dots and characters of which the maps were composed as symbols and observed the manipulation of these by the computer. In Newell, Simon found an eager ear for such insights. The two developed the idea that both computers and minds manipulated symbols and, hence, the computers could simulate human problem solving, with computer languages providing formal descriptions of such operations." (Sent, 2000: 395)

75 A partir da década de 1960, a principal fonte de recursos para pesquisa em ciência cognitiva na CarnegieMellon foi o National Institute of Mental Health (Simon, 1996a: 255), mas não sei se para a dupla, em particular.
} 
econometrics. Moreover, Cowles had close ties with the RAND Corporation (an acronym for Research and National Development), the original Think Tank, located in Santa Monica, and largely funded by the Air Force. RAND was well keyed into the early developments in cybernetics and computing.

... For centrality to the postwar quantitative social sciences, the Cowles Commission and the RAND Corporation were definitely the places to see and be seen. My presence in these places made Administrative Behavior visible not merely to scholars in the discipline of public administration but to others, as well, who could sense how crucial decision processes are to explaining human rationality. Thus Administrative Behavior did not languish in its provincial homeland, but was noticed by economists and decision theorists. It was also noted by sociologists and the new community of behavioral scientists... (Simon, 1996a: 115-6)

No que tange ao conteúdo da pesquisa de Simon, Sent (2000: 388) relata que nesse processo seu foco mudou da teoria organizacional para ciência cognitiva, de evidência negativa para simulações positivas, de problemas bem estruturados para problemas pouco estruturados, de decisões programadas para soluções não programadas, de decisões algorítmicas para soluções heurísticas, em suma, da tomada de decisões para a solução de problemas. Cito extensamente a visão do próprio Simon da situação:

The most important years of my life as a scientist were 1955 and 1956, when the maze branched in the most unexpected way. During the preceding twenty years, my principal research had dealt with organizations and how the people who manage them make decisions. My empirical work had carried me into real-world organizations to observe them and occasionally to carry out experiments on them. My theorizing used ordinary language or the sorts of mathematics then commonly employed in economics. Although I was somewhat interdisciplinary in outlook, I still fit rather comfortably the label of political scientist or economist and was generally regarded as one or both of these.

All of this changed radically in the last months of 1955. While I did not immediately drop all of my concerns with administration and economics, the focus of my attention and efforts turned sharply to the psychology of human problem solving, specifically, to discovering the symbolic processes that people use in thinking. Henceforth, I studied these processes in the psychological laboratory and wrote my theories in the peculiar formal language that are used to program computers. Soon I was transformed professionally into a cognitive psychologist and computer scientist, almost abandoning my earlier professional identity. (Simon, 1996a: 189, ênfase minha)

É interessante notar o paralelo entre essa mudança na agenda de pesquisa de Simon e as transformações a que me referi no conteúdo da pesquisa operacional que então vinham ocorrendo na RAND, que se dirigiam mais para problemas de planejamento militar, no que veio a ser chamado de análise de sistemas. ${ }^{76}$

\footnotetext{
${ }^{76}$ A distinção entre pesquisa operacional e análise de sistemas feita por Fortun e Schweber deixa isso claro. Compare a lista de Sent com a distinção feita pelos autores entre estas: "Traditional operations research, for the most part, addressed problems where the objectives were precisely spelled out, and the existing systems and
} 
Estas considerações apontam para um afastamento efetivo de Simon da economia a partir deste momento, mas este fato nos coloca uma questão. Como alguém que praticamente deixou a economia de lado desde meados da década de 1950 veio a receber o prêmio Nobel no final da década de 1970? E com o agravante de que as idéias econômicas dele não eram exatamente ortodoxas. Simon (1996a: 325-326) se dá conta desse conflito e nota que "[ele] ter sido escolhido para o prêmio causou algum espanto". Sua interpretação da resposta, em resumo é que: "se eu era um outsider para a profissão econômica como um todo, eu era um insider na sua elite". Por "elite" ele se refere basicamente à Econometric Society, que por sua vez tinha uma razoável intersecção de membros com a Comissão Cowles. ${ }^{77}$

Em outras palavras, ele não era apenas muito inteligente, mas também muito bem relacionado e influente. Uma leitura minimamente atenta da autobiografia de Simon (1996a) revela um cientista consciente do fato de que as disputas acadêmicas são tanto intelectuais quanto políticas e ativo em ambas essas esferas. Vale a pena analisar a atividade política de Simon, mas, antes disso cabe falar do retorno dele aos debates na economia, que girou em torno do prêmio Nobel, num daqueles fatos curiosos da vida.

Earlier the same year [1969], Carnegie Mellon had held a joint seminar with faculty members of business schools in Scandinavia, conducted in Aspenäs, Sweden. Walter Goldberg, a business economist of Gothenberg University, was the prime mover. One sunny afternoon during the seminar, we took a break from our discussions to gather on the lawn for academic gossip. One topic was the newly announced and not yet awarded economics prize. Who would win it? At some point of the conversation, Walter Goldberg turned to me and said, 'You will receive the prize in ten years.' I expressed and felt incredulity - however much I secretly believed I merited such an award, economists did not regard me as an economist; and bounded rationality seemed to be dying a quiet death, in the United States at least. The neoclassicists clearly had won the day. (Simon, 1996a: 319)

weapons (the 'hardware') were considered fixed and unchangeable. OR was usually concerned with tactical problems and could be stated quantitatively and mathematically, and the aim of the analysis was 'to find more efficient ways to operate, in situations where the meaning of "more efficient" is fairly clear'. OR problems usually admitted a unique solution that represented the optimal allocation of the hardware available to the decision maker." (Fortun and Schweber, 1993: 606-607); com relação à: "Systems analysis, on the other hand, refers to the far more complex problem of choice among alternative future systems, where the degrees of freedom and the uncertainties are large, where the difficulty lies as much in deciding what ought to be done as in how to do it.... The total analysis is thus a complex and untidy procedure, often with little emphasis on mathematical models, with no possibility of quantitative optimization over the whole problem, and with necessary great dependence on considered judgments." (Rand Corporation apud Fortun e Schweber, 1993: 607)

${ }^{77}$ Se avaliada por prêmios Nobel a "elite" parece bem caracterizada por Simon: "If you examine the list of Fellows of the Econometric Society in 1954, fifteen years before the first Nobel Prize in economics was awarded, you will find the names of 20 of the first 27 prizewinners." (Simon, 1996a: 326). "In its early years, the award of the Nobel Prize in economics was almost coextensive with the list of economists affiliated with the Cowles Commission." (Mirowski, 1999: 706). 
Goldberg organizou a candidatura de Simon ao prêmio. A partir daí, "uma vez plantada a semente do desejo", ele passou a aceitar convites que, em outras circunstâncias, recusaria e retomou a polêmica com os economistas. A antecipação da possibilidade do prêmio o levou a “fazer campanha" (Simon, 1996a: 324). Alguns trabalhos importantes de Simon, dentre os voltados à economia, tiveram sua origem aí, sendo o mais conhecido From substantive to procedural rationality (1976b). E, após ter ganho o prêmio em 1978, Simon usou a inserção e exposição que dele resultaram para retomar discussões e rever algumas de suas posições no que diz respeito à economia, à luz de suas pesquisas em ciência cognitiva. Contudo, isso não alterou o foco principal de sua agenda de pesquisa, ele "[dedicou] talvez 5\% a mais de [sua] energia total à economia", tratou-se de "uma leve curva na estrada" (p. 324). ${ }^{78}$

\subsubsection{Simon, pesquisa operacional e ciências sociais}

Mirowski (1999: 686) sugere que, para entender as maneiras pelas quais a física infiltrou-se nas ciências sociais durante o século XX, maior atenção deverá ser dada aos imperativos militares, à política científica e à pesquisa operacional. Em particular, segundo ele, a "sub-pesquisada história da pesquisa operacional" é a parte que falta no argumento. $\mathrm{O}$ próprio Mirowski tratou do caso da economia, mas deixou em aberto os casos de outras ciências sociais.

Neste espaço, a própria figura de Simon pode ser olhada como um elo nessa ligação, afinal ele veio a ocupar, no período pós-guerra, posições de destaque em ambos os círculos. Todavia, me parece mais complicado saber exatamente o que fazer disso. Acho pouco, do ponto de vista de quem quer entender este processo histórico, tentar olhar para a influência efetiva da sua atividade política por si só, primeiro porque é muito difícil, se não impossível, avaliar quais os efeitos que ela teve ou não. E segundo porque fazê-lo nos obrigaria a olhar para a vida de cada um dos participantes dos eventos, o que talvez fosse necessário para provar determinadas coisas, mas não em absoluto para ter uma compreensão do processo. Por outro lado, é difícil justificar que Simon é representativo, em qualquer sentido estatístico, do processo. Ao contrário, levamos algumas páginas no início deste capítulo mostrando suas excepcionalidades. Podemos, creio, tomar Simon como um “estudo de caso". Podemos tomar

\footnotetext{
${ }^{78}$ Explicitamente: "Most of my research in the decade after receiving the Nobel Prize continued to be directed toward cognitive science, often pushing forward along the paths marked out earlier." (Simon, 1996a: 327)
} 
sua história como ilustrativa da movimentação histórica mais ampla. Entendo que o estudo conjunto, tal como foi feito aqui, da carreira e do trabalho de Simon e do contexto em que se inserem, permite identificar alguns elementos chave do processo histórico e alcançar algum entendimento sobre os seus desenlaces. Partindo de Simon, pudemos identificar instituições, estratégias, personagens e eventos que podem ser utilizados como uma chave interpretativa de outros processos relacionados. Estas considerações servem, por um lado, para colocar o que viemos discutindo desde o começo do capítulo até o momento como uma resposta parcial ao mote de Mirowski. ${ }^{79}$ Por outro lado, revelam alguns temas relacionados a este mote que poderíamos explorar. Há dois temas que gostaria de discutir ainda: a atividade política de Simon no interior da academia e, a título de exemplo, um rápido olhar sobre a história da sociologia norte-americana à luz do contexto histórico traçado aqui.

Simon foi politicamente ativo durante a maior parte de sua carreira acadêmica, mas sempre exerceu esta atividade em paralelo às suas atividades acadêmicas e sempre a partir de sua posição de cientista. Ele atuou tanto na política acadêmica, quanto num escopo político mais amplo, principalmente a partir dos comitês consultivos (advisory committees) para o governo norte-americano que se institucionalizaram no pós-guerra, incluindo aí uma participação na implantação do Plano Marshall.

Sua mobilização política se iniciou no âmbito da ciência política e logo das ciências sociais em geral. Logo após a Segunda Guerra, enquanto ainda no Illinois Tech, seu envolvimento era com as mobilizações oriundas da "revolução comportamental", a que me referi acima quando discutia a passagem de Simon pela Universidade de Chicago, no interior da American Political Science Association (Simon, 1996a: 169). Em 1951, Bernard Berelson começou a consultá-lo a respeito da nova Divisão de Ciências Comportamentais (Behavioral Sciences Division) da Fundação Ford (p. 170). Durante a década de 1950 ele também foi convidado a participar de alguns comitês do Social Science Research Council (SSRC), para em 1958 ser chamado a fazer parte da diretoria do conselho, posição que manteve até 1971, tendo inclusive, presidido o referido conselho por cinco anos durante este período. Simon atesta que "no topo da [sua] agenda para o SSRC estavam o apoio para o treinamento matemático de cientistas sociais e a erosão das fronteiras entre disciplinas” (1996a: 172).

\footnotetext{
${ }^{79}$ O próprio Mirowski (1999: 698) sugere que uma boa forma de mostrar o poder do patrocínio militar é estudar a carreira de cientistas individuais.
} 
A partir de meados dos anos 1960, Simon e outros cientistas sociais iniciaram articulações no sentido de ampliar a participação das "ciências sociais e comportamentais" na National Academy of Sciences (NAS). Simon foi o segundo a ser eleito para a Academia a partir desses esforços, no ano de 1967, após o demógrafo Kingsley Davis em 1966 (p. 293). Em seguida, foram incorporados também Kenneth Arrow, Robert Merton, Tjalling Koopmans e Paul Samuelson. Em 1972, a mobilização culminou com o reconhecimento da "classe de ciências sociais e comportamentais" na Academia (p. 293) ${ }^{80}$ O critério utilizado para a seleção dos novos membros não era exatamente pluralista:

We made the decision at the outset to bring in younger members, even at the expense of postponing the nominations of such senior, and outstanding, candidates as Ted Newcomb and Paul Lazarsfeld. We did elect those two during their lifetimes, but I always felt a little badly about the injustice of the delay in their elections, however justified it was from strategic standpoint. Talcott Parsons was also passed over, but in this case it was because some of us thought him too 'soft' to qualify. (Simon, 1996a: 294)

Já no ano seguinte à sua eleição Simon foi convidado para participar do prestigioso Committee on Science and Public Policy (COSPUP), e logo na seqüência, também para o U.S. President's Science Advisory Committee (PSAC), tendo o fato sido reconhecido como a primeira participação de um cientista social neste comitê (p. 294). ${ }^{81}$ Embora estes esforços de Simon possam ser reconhecidos como tendo gerado um enclave social-científico num território previamente dominado pelos cientistas naturais por excelência, os físicos, ele viria a resumir os objetivos de seus esforços nos seguintes termos:

In the 'politics' of science ... I have had two guiding principles - to work for the 'hardening' of the social sciences so that they will be better equipped with the tools they need for their difficult research tasks; and to work for close relations between natural scientists and social scientists so that they can jointly contribute their special knowledge and skills to those many complex questions of public policy that call for both kinds of wisdom. (Simon, 1978b: 4) 82 $^{82}$

\footnotetext{
${ }^{80}$ Simon estava bastante envolvido no processo: "I was heavily engaged in the nominating and election process during these years, playing a major, although not always decisive, role in shaping the new social science membership." (Simon, 1996a: 293)

${ }^{81}$ Embora, mais tarde Simon veio a saber que foi escolhido para o PSAC como especialista em inteligência artificial e ciências da computação (p. 295).

${ }^{82}$ Discutiremos esta posição de Simon com um pouco mais de detalhe na próxima seção.
} 
Havendo tratado a atividade política de Simon, passemos ao nosso segundo tema: o caso da sociologia. ${ }^{83}$ Wiley (1979) faz uma reconstrução analítica da história da sociologia americana a partir das teorias sociológicas dominantes ao longo do século XX. Do nosso ponto de vista, o que é interessante nesta história é o gradual e regular crescimento do controle sobre os "meios de produção intelectual" por parte do que ele chama de "a ala positivista" da sociologia a partir da década de 1930, e a eventual ascensão desta ala a grupo dominante ao final dos anos 1960. O autor define meios de produção intelectual como as ferramentas ou a propriedade produtiva da disciplina: cargos profissionais, acesso a publicação em periódicos, estudantes de pós-graduação, acesso a editores comerciais e universitários, dinheiro para pesquisa e controle de estruturas organizacionais e cerimoniais das principais associações profisssionais da disciplina (p. 48). Quanto à definição de "positivista", Wiley nota que o termo é informalmente usado para identificar aqueles que pertencem ao lado matemático ou altamente quantificado da sociologia. "Positivismo" denomina também comumente cientificismo, "ou o dito de que a sociologia deve usar modelos da ciência natural deixando de lado empatia / gestalt / teleologia / verstehen / tipificação / afinidade eletiva / dialética / funcionalismo, e assim por diante, exceto como um dispositivo heurístico pré-científico". Também pode significar ver os símbolos como concretos, como "externos e coercitivos" no sentido durkheimniano. Wiley faz uso dos três sentidos do termo:

I shall make the assumption that the three definitions - highly quantified, scientistic, and social factist - tend to be found together; that is, the same people tend to have all three traits of methodological commitments, though they do not always go together, and there is some precision lost using the term. (Wiley, 1979: 50)

Se olharmos a afinidade com a pesquisa operacional como um importante critério de seleção para o acesso aos fartos recursos federais disponíveis a partir da guerra, a história da sociologia norte-americana pode ser melhor compreendida, em particular, a ascensão gradual dos "positivistas". Duas características que claramente compõem esta afinidade são: (1) em função da proeminência que os físicos tiveram no processo, a proximidade com a física ou, no

\footnotetext{
${ }^{83}$ Outras ciências sociais, claramente, estiveram envolvidas no processo. Tomo a sociologia simplesmente em função da minha familiaridade (um pouco) maior com a história desta disciplina nos EUA. Quando penso na maneira em que este processo histórico se relaciona com a ciência política penso na crescente afinidade desta disciplina com a economia, em particular nos EUA. No caso da antropologia me vêm imediatamente à mente $O$ crisântemo e a espada de Ruth Benedict, de 1946, e a ida de Clifford Geertz à Indonésia e o contexto no qual ela
} 
mínimo, uma linguagem comum: a matemática; (2) a produção de conhecimento (diretamente ou, ao menos, que alegasse ser) útil para a tomada de decisão militar, governamental ou administrativa: previsão e controle.

Sugiro, como hipótese, que a matemática tinha ainda um outro papel, aparentemente ela era um importante elemento de identidade dentro deste grupo, ela fornecia credenciais. Acredito que os integrantes do grupo se reconheceriam antes como "cientistas sociais matemáticos" do que como "positivistas", ${ }^{84}$ dando algum fundamento ao uso informal deste último termo, mesmo concordando com a hipótese de Wiley de que as três características freqüentemente andam juntas. A Fundação Ford, através de Bernard Berelson, ajudou a disseminar um outro rótulo ainda, o de "ciências comportamentais" (behavioral sciences). Não sei exatamente o quanto estes dois rótulos são coextensivos, mas há razão para supor que a intersecção é grande (veja Berelson, 1963, em particular a introdução de Berelson e a lista de contribuidores). ${ }^{85}$ Nas palavras de Simon, se referindo à ciência política, temos uma amostra da matemática sendo trazida ao centro da questão: ${ }^{86}$

The battle is long over, and we are all winners. Mathematics and statistics were brought to political science by the summer workshops of the Social Science Research Council and later, the Mathematical Social Science Board. (Simon, 1996a: 63) ${ }^{87}$

Um ponto importante a se notar é que duas das características pelas quais a "ala positivista" foi mais criticada não são, a priori, traços do positivismo propriamente dito, mas são antes associadas à pesquisa operacional: a organização burocratizada da pesquisa em grandes grupos e a transformação do pesquisador em um técnico especializado (Mills, 1959;

se insere: estudos que visavam avaliar os efeitos da modernização em "Estados recém-independentes" (Kuper, 2002). Mas seguramente muitos outros exemplos poderiam ser encontrados.

${ }^{84}$ Eu mesmo não estou plenamente confortável com o uso do termo "positivista" para denominar este grupo, o usarei aqui entre aspas para que tenhamos em mente que se trata antes da delimitação de um grupo do que de uma filiação filosófica, a despeito da intersecção entre as coisas.

${ }^{85}$ De qualquer maneira, ser "cientista comportamental" era o critério para o acesso a recursos: "For about six years in the 1950's the Foundation operated a Behavioral Sciences Program and supported this field with several millions of dollars. It was then that the term came into widespread use, and it was then that some people began to wonder whether they too were not behavioral scientists after all!" (p. 4).

${ }^{86}$ Não se pode excluir a hipótese, todavia, da matemática ser deliberadamente usada como "roupagem". Mas não tenho como avaliá-la.

${ }^{87}$ Curioso é Simon, ao tentar inserir o departamento de ciência política em um movimento mais amplo, citar principalmente sociólogos ligados à Universidade de Columbia: "In assessing the influence of the Chicago School upon political science, one must avoid the fallacy of post hoc, propter hoc. ... One could just as easily find the first cause in Columbia's Sociology Department (Paul Lazarsfeld), Harvard's Sociology Department (Samuel Stouffer), the Survey Research Center at Michigan, or the pioneering, and very early, contributions of Franklin Giddings, Stuart Rice, and Malcom Willey.” (Simon, 1996a: 62) 
Nisbet, 1962; Pollak, 1986). A interdisciplinaridade também aparece de forma marcada nas manifestações mais claras, como nas ciências comportamentais. O simples fato destas duas coisas - "positivismo" e pesquisa operacional - terem se manifestado juntas historicamente deveria ser esclarecedor por si só.

Neste contexto, fica mais fácil compreender a projeção que atingiram, por exemplo, Paul Lazarsfeld (Pollak, 1986) e mesmo Samuel Stouffer após a guerra e, de forma correspondente, o sucesso das técnicas de survey e da estatística na sociologia norteamericana. É neste contexto que surge um volume como The policy sciences (Lerner e Lasswell, 1951), onde a ciência (social) dá uma mão à política e com a outra celebra a união. ${ }^{88}$ A continuidade das relações estabelecidas em torno da pesquisa operacional ao longo da Guerra Fria, se esta interpretação estiver correta, também lança luz à injeção sistemática de recursos nesta ala da sociologia no período.

\subsection{Questões metodológicas}

O propósito desta seção é fornecer, num outro plano, o metodológico, uma contextualização para a apresentação do trabalho de Simon. Aqui discutiremos um pouco a atividade científica de Simon enquanto tal, o que significa que além de situar os capítulos que se seguem, onde apresentarei a teoria comportamental de Simon, estaremos tratando também de seus fundamentos. Não discutirei méritos ou deméritos das posições esposadas por ele, apenas aponto alguns elementos que acho que devem ser entendidos como pano de fundo para suas teorias propriamente ditas. Um sucinto e claro manifesto do entendimento do autor a respeito do "processo científico" pode ser encontrado em Simon (1968). ${ }^{89}$ Os elementos que

\footnotetext{
${ }^{88}$ Vale comparar o prefácio, em particular as páginas ix-x, onde Charles Rothwell descreve como "as ciências da sociedade" são essenciais à "formulação e aplicação de políticas", com as descrições da pesquisa operacional feitas acima. No mesmo volume encontramos, nas palavras de Lasswell: "The rise of economists and psychometricians seemed to indicate that the closer the social scientist came to the methods of physical science the more certain his methods could be of acceptance. This point of view was emphasized by the scholar who took the most important part in remolding the social disciplines, Charles E. Merriam, professor of political science at the University of Chicago. Professor Merriam took the initiative in organizing the Social Science Research Council..." (p. 6-7) etc.

${ }^{89}$ Uma ponto interessante deste texto é o enorme ceticismo demonstrado por ele com relação à capacidade de testes estatísticos proverem critério para teste de hipóteses extremas e, portanto, para julgar teorias.
} 
apresento aqui podem ser amostrados também em Simon (1977) e mesmo ao longo de sua obra em geral.

\subsubsection{Positivismo lógico}

Simon foi um positivista lógico de discurso e de prática. ${ }^{90}$ Mas, como o positivismo lógico ao longo do século passado gerou grandes controvérsias e veio a mobilizar os ânimos, este ponto me coloca numa situação delicada aqui. Por isso, tomarei como mote, neste percurso, um par de comentários do próprio Simon a respeito de suas convicções:

I had already [as an undergraduate in Chicago] embraced a logical positivism that I have never relinquished (I would prefer to call it empiricism now)... (Simon, 1996a: 44) ${ }^{91}$

It is true that I am still accused of 'positivism' as though that were some kind of felony, or at least a venial sin; and there still seems to be widespread lack of understanding of why one cannot logically deduce an 'ought' without including at least one 'ought' among the premises. ... [These difficulties] arise from the general tendency today to use positivist as a pejorative term without any clear notion of what positivists believe. (Simon, 1996a: $270)^{92}$

Dito isto, minha proposta é dar uma "noção mais clara" do que o professo "positivista Simon" acreditava e praticava, em particular do que ele acreditava ser ciência, e como a praticava, levantando alguns traços que podem ser encontrados consistentemente em sua obra. Este levantamento não é, em princípio, exaustivo, ele é um subproduto das leituras realizadas com outros olhos, mas nem por isso é descartável ou menos interessante. É importante notar que, no entanto, tal levantamento seria difícil de realizar, num trabalho como este, não fosse a reflexão constante do próprio autor sobre estas questões. Simon não era ingênuo com relação a estas discussões e suas posições neste plano, no geral, são pensadas e refletidas.

Antes disso, porém, vale falar novamente de Rudolf Carnap, que foi professor de Simon em Chicago. Quando comentei a respeito da influência dele sobre Simon, não mencionei que

\footnotetext{
${ }^{90}$ Refiro-me, agora, antes a seu posicionamento filosófico que a seu pertencimento ao grupo "positivista" das ciências sociais.

${ }^{91}$ Cabe notar que, comumente, o empiricismo lógico e positivismo lógico se referem à mesma doutrina e são usados como sinônimos.

${ }^{92}$ Há outras referências na autobiografia de Simon sobre sua vinculação com o positivismo lógico (1996a: 75, $85,361)$.
} 
Carnap era um eminente membro do Círculo de Viena, um dos berços do positivismo lógico. ${ }^{93}$ Simon não era muito assíduo a aulas em geral, mas:

I attended, with more diligence than usual, several of Rudolf Carnap's courses in logic and philosophy of science. All three men [Carnap, Schultz e Rashevsky] communicated to me in their lectures something of how science - at least science involving the applications of mathematics - was done.

Carnap was particularly important to me, for I had a strong interest in the logic of the social sciences. My thesis project (later published as Administrative Behavior) started out as a study of the logical foundations of administrative science. (Simon, 1996a: 53, ênfase minha)

\subsubsection{Empiricismo}

Simon tem uma forte aderência à empiria em todo o seu trabalho, para ele a empiria - a experiência e a observação - é a base sobre a qual a ciência deve ser construída. Mesmo seu esforço teórico mantinha sempre em vista as questões empíricas suscitadas. Administrative Behavior foi um trabalho eminentemente teórico e sua parte empírica, o próprio Simon admite, era quase toda baseada em senso comum e introspecção. Mas o esforço teórico ali realizado era subordinado ao empírico:

But this reliance of administrative theory on common sense was not entirely acceptable to me. Systematic observation and experimentation were badly needed if this field was ever to become scientific. But until someone built a satisfactory theoretical framework, it would not be clear what kinds of empirical studies were called for.

These reflections planted the first seeds of Administrative Behavior. I decided to write a theoretical doctoral thesis on decision making in administration, thereby modifying my earlier intent to write on the logic of administration. The thesis would raise many empirical questions that could be explored subsequently in my research. This decision set the central strategy for my research in organizations over the next twenty years ... (Simon, 1996a: 73-4)

Os argumentos de Simon estão recheados de - e freqüentemente têm como elemento central - expressões do tipo: "de fato", "na prática", "na realidade", "no mundo real", "na vida real", "realmente", "de maneira realística" etc. ${ }^{94}$ Como veremos adiante este é, de fato, o argumento que Simon emprega contra a hiperracionalidade neoclássica. Para ele, os "fatos" são o "supremo tribunal científico":

\footnotetext{
${ }^{93}$ Segundo a entrada na enciclopédia Britannica, o Círculo de Viena foi fundado na década de 1920 por Moritz Schlick, sendo formado por filósofos, cientistas e matemáticos. Pouco antes do início da Segunda Guerra muitos de seus membros migraram para os EUA e alguns para a Inglaterra. Para um tratamento mais adequado do positivismo lógico, ainda sucinto mas menos acessível, veja Bergmann (1967).

${ }_{94}$ É interessante notar que, na concepção de Simon, "o mundo real" é lógico: "It cannot be a contradiction, because it is a fact of the world; and the world is as it is, and cannot contradict itself." (Simon, 1996a: 340)
} 
Science, viewed as competition among theories, has an unmatched advantage over all other forms of intellectual competition. In the long run (no more than centuries), the winner succeeds not by superior rhetoric, not by the ability to convince or dazzle a lay audience, not by political influence, but by the support of the data, facts as they are gradually and cumulatively revealed. As long as its factual veridicality is unchallenged, one can remain calm about the future of a theory. The future of bounded rationality is wholly secure. (Simon, 1996a: 364-365, ênfase minha)

Contudo, há mais do que "fatos" aqui. Dessa perspectiva, o objetivo da ciência é a veracidade factual, a ciência se debruça sobre questões factuais. Isso não quer dizer que questões normativas estejam fora da pauta. Neste tipo de questão, a ciência pode ajudar a separar o conteúdo factual do valorativo e a avaliar o primeiro. ${ }^{95} \mathrm{O}$ pressuposto implícito nesta posição é a "guilhotina de Hume", que estabelece um isolamento lógico entre fatos e valores. A guilhotina corresponde à proposição de que "não se pode deduzir o que deve ser do que é”, ou, em outras palavras, que afirmações puramente factuais, ou descritivas, podem implicar apenas outras afirmações factuais, mas nunca podemos chegar a uma norma, a uma afirmação ética, prescritiva, sem introduzir ao menos um julgamento de valor (Blaug, 1980: 130). O leitor provavelmente notará adiante a relação desta proposição com a própria noção de racionalidade adotada por Simon. Mas, como o ponto é importante, explicito:

Reason, taken by itself, is instrumental. It can't select our final goals, nor can it mediate for us in pure conflicts over what final goal to pursue - we have to settle these in some other way. (Simon, 1983: 106)

\subsubsection{A mãe de todas}

Simon tinha a física como o modelo de ciência. E, com isso, veio junto a formalização, a matemática, e a gana de tornar as ciências sociais mais "duras". O projeto pessoal de aproximar as ciências sociais das naturais orientou sua atividade científica desce cedo, "a física já tinha ido muito longe (pensava [ele]) para aventura genuína” (1996a: 366):

By the time I was ready to enter the University of Chicago, in 1933, I had a general sense of direction. The social sciences, I thought, needed the same kind of rigor and the same mathematical underpinnings that had made the 'hard' sciences so brilliantly successful. I would prepare myself to become a mathematical social scientist. ... I also made a serious study of graduate-level physics in order to strengthen and practice my mathematical skills and to gain an intimate knowledge of what 'hard' science was like, particularly on the

\footnotetext{
${ }^{95}$ Um exemplo de que Simon gostava - e que discutiu na defesa de sua dissertação de Ph.D. em 1942 (1996a: 85) e mais tarde (1983: 8-10) - mesmo sendo filho de um judeu, talvez para chocar, era Hitler: "The examiners ... found it difficult to believe that one could not prove, from self-evident premises, that Hitler was a bad man. And if one couldn't prove it, what right had one to believe it?" (1996a: 85)
} 
theoretical side. An unexpected by-product of the latter study has been a lifelong interest in the philosophy of physics and several publications on the axiomatization of classical mechanics. (Simon, 1978b: 2, ênfase minha)

Cabe ressaltar, no entanto, que isso se dava num plano bastante geral. Não me recordo de ter encontrado alguma analogia explícita a modelos físicos específicos entre as coisas que li. Acredito ser mais apropriado pensar nesta influência como residindo mais "na forma da ciência" que "no conteúdo da ciência" de Simon, talvez "estilo" seja a palavra mais precisa. ${ }^{96}$

Com relação ao uso da matemática por Simon é relevante apontar que ele não era particularmente dado à "pirotecnia". ${ }^{97}$ De acordo com o próprio (1996a: 106-107), para ele a matemática era uma forma de pensar, "uma ferramenta que [usava] para chegar a novas idéias". Ele fazia uso "da matemática do físico ou da matemática do engenheiro ao invés da matemática do matemático". A despeito das ressalvas, para fins científicos, a matemática é para ele, sem dúvida, melhor linguagem que a de uso corrente: ${ }^{98}$

... I should like to argue that the mathematical translation is itself a substantive contribution to the theory. Mathematics has become the dominant language of the natural sciences not because it is quantitative - a common delusion - but primarily because it permits clear and rigorous reasoning about phenomena too complex to be handled in words. This advantage of mathematics over cruder languages should prove of even greater significance in the social sciences, which deal with phenomena of the greatest complexity, than it has in the natural sciences. (Simon, 1957: 89)

Ainda assim, para ele, a quantificação das teorias era essencial, o que nos leva ao próximo item.

\subsubsection{Operacionalidade}

$\mathrm{Na}$ visão de Simon, uma variável qualquer, para ter significado empírico, deve ser mensurável. Para tanto, ela deve receber uma definição operacional, o que quer dizer que a maneira como a variável deverá ser medida deve ser especificado. Além disso, como vimos,

\footnotetext{
96 "The social sciences have been accustomed to look for models in the most spectacular successes of the natural sciences. There is no harm in that, provided that it is not don in a spirit of slavish imitation. In economics, it has been common enough to admire Newtonian mechanics (or, as we have seen, the Law of the Falling Bodies), and to search for the economic equivalent of the laws of motion. But it is not the only model for a science, and it seems, indeed, not to be the right one for our purposes." (Simon, 1979a: 510)

${ }^{97}$ O próprio Simon (1977: xv) afirma isso, mas eu mesmo endosso a afirmação ao comparar seu trabalho com outros na área da economia.

${ }^{98}$ A esse respeito veja Simon (1954b).
} 
de sua perspectiva a ciência se volta para questões empíricas. Mas para ele empiria era sinônimo de medida:

The first task of administrative theory is to develop a set of concepts that will permit the description, in terms relevant to the theory, of administrative situations. These concepts, to be scientifically useful, must be operational; that is, their meanings must correspond to empirically observable facts or situations. (Simon, 1947: 37) ${ }^{99}$

Simon tinha uma preocupação constante com a operacionalidade das variáveis com que trabalhava em suas teorias. ${ }^{100}$ Não acho inapropriado, por exemplo, tomar os trabalhos do autor sobre causalidade (Simon, 1952, 1953a, 1954a) como uma tentativa de tornar operacional a assimetria da relação entre as variáveis que a noção de causalidade carrega. Mas, mais do que isso, a operacionalidade foi incorporada na própria noção de racionalidade do autor. A racionalidade só pode ser exercida com relação a objetivos operacionais. ${ }^{101}$ Esta relação aparecerá adiante em nossa discussão.

Além disso, Simon alegava que muito das críticas contra a “'quantificação' ou 'medida' de variáveis 'qualitativas' encontradas nas ciências sociais" tinham sua origem na ignorância da flexibilidade que o conceito de quantidade possui (Simon, 1953b: 75n).

\subsubsection{Racionalismo e individualismo metodológico}

É ainda uma pergunta para mim se Simon poderia ser apropriadamente qualificado como racionalista e/ou individualista metodológico em sentido estrito. No entanto, sua obra se caracteriza por uma enorme ênfase no comportamento individual racional, o que, por si só, justifica tecer algumas considerações a respeito. Isto implicará numa utilização "adiantada" de alguns elementos da teoria e, talvez, a discussão feita aqui só venha a ficar mais clara mais adiante. No entanto, acho relevante ressaltar estas questões de antemão pois elas sugerem algumas linhas que serão encontradas ao longo de todo o estudo, e nem sempre de maneira evidente.

No trabalho de Simon o termo comportamento usualmente vem acompanhado de uma qualificação. Nos trabalhos aqui discutidos, a qualificação mais freqüente, implícita ou

\footnotetext{
${ }^{99}$ Acredito que Simon teria escrito isso de qualquer teoria, não apenas da teoria da administração.

${ }^{100}$ A coletânea de artigos em Simon (1957) é um bom exemplo disso.

${ }^{101}$ A operacionalidade dos objetivos é questão de grau, no entanto (March e Simon, 1958: 156).
} 
explicitamente, é o "comportamento humano individual no interior de organizações". ${ }^{102}$ Ainda assim, podemos distinguir pelo menos quatro âmbitos importantes para o comportamento humano na obra de Simon, distribuídos em duas oposições: o comportamento individual vs o comportamento organizacional, e comportamento individual no interior de organizações vs comportamento em geral (fora delas, ou não necessariamente dentro delas). Argumento que, embora estes âmbitos não sejam idênticos, a forma dele teorizar um é amplamente análoga às demais, as diferenças estando em geral apenas em sutilezas e ênfases de interpretação. ${ }^{103}$ A estrutura formal da teoria é a mesma para os quatro âmbitos. Mas é interessante aqui analisarmos um pouco das diferenças entre eles.

Primeiro, tratemos da distinção entre o comportamento no interior de organizações e o comportamento em geral. A definição de Simon para organização é bastante fluida, tentando capturar muito mais do que o termo denota no senso comum. Podemos dizer que organização, tal como pensada por ele, tem a ver com algum nível de interação significativa entre indivíduos do ponto de vista de um determinado fenômeno que se pretende estudar. A diferença entre organização e sociedade passa a ser uma questão de grau (March e Simon, 1958: 3), conforme argumentarei com mais propriedade no quarto capítulo.

A distinção entre comportamento individual e comportamento organizacional requer alguns cuidados também. Simon, em diversas instâncias olha a organização como um sujeito, e nesse sentido fala em comportamento organizacional - o comportamento da organização. No entanto, embora a organização, vista desta maneira, possa galgar graus mais elevados de racionalidade que o indivíduo, no sentido de que consegue se aproximar mais de seus objetivos do que indivíduos não organizados poderiam, as restrições à racionalidade também se aplicam (como veremos) a ela, e os mecanismos adotados para driblá-las são análogos aos utilizados pelos indivíduos. A teoria comportamental de Administrative Behavior (Simon, 1947 e 1976a) e de Organizations (March e Simon, 1958) se aplica a ambos os âmbitos comportamentais. No entanto, o comportamento individual e, de maneira correspondente, a psicologia são privilegiados por Simon em sua obra. Como bem coloca Silveira (1983: 603), "o fio da meada é o estudo do decisor".

\footnotetext{
${ }^{102}$ Possivelmente esta afirmação não valha para a obra de Simon em geral. Se considerarmos o tempo da carreira de Simon em que seu principal envolvimento foi com a ciência cognitiva e a inteligência artificial, talvez o contexto mais adequado seja simplesmente o "comportamento humano individual".

${ }^{103}$ Veja, por exemplo, Simon (1972: 161).
} 
A estrutura organizacional é resultante das próprias restrições à racionalidade individuais, o comportamento organizacional é resultante do complexo de comportamentos individuais no interior da organização. Ainda no que tange à composição da organização por indivíduos, eu poderia citar a feição contratualista da teoria do equilíbrio organizacional utilizada por Simon, que discutiremos com mais detalhes adiante, onde a existência da organização, e seu objetivo, se transveste num meio para a realização (indireta) dos objetivos pessoais dos seus membros. ${ }^{104}$ Numa das únicas referências que encontrei de uma manifestação direta de Simon sobre reducionismo, mas que me parece consistente com muito de seu trabalho, temos o seguinte:

By adopting this weak interpretation of emergence [i.e., the parts of a complex system have mutual relations that do not exist for the parts in isolation], we can adhere (and I will adhere) to reductionism in principle even though it is not easy (often not even computationally feasible) to infer rigorously the properties of the whole from knowledge of the properties of the parts. (Simon, 1996b: 172)

Eu não contestaria que existe uma forte tendência no trabalho de Simon de explicar os fenômenos sociais a partir da racionalidade individual, entretanto, me parece difícil fazer sobre ele a afirmação categórica de que é um individualista metodológico no sentido de que "aceita explicações de fenômenos sociais somente se elas forem erigidas como o resultado de interações individuais explicáveis" (Foley, 2003: 7, ênfase minha).

Em primeiro lugar, há contra-exemplos. Há os trabalhos de Simon sobre a distribuição do tamanho de firmas, ${ }^{105}$ mobilizados por ele contra a teoria neoclássica como uma explicação mais parcimoniosa para o fenômeno, em que utilizava um mecanismo probabilístico como forma de explicação. Mas, no conjunto, estes casos tendem a ser antes a exceção que a regra.

\footnotetext{
104 "In an organization such as that just described, there appears, in addition to the personal aims of the participants, an organization objective, or objectives. If the organization is a shoe factory, for example, it assumes the objective of making shoes. Whose objective is this - the entrepreneur's, the customers', or the employees'? To deny that it belongs to any of these would seem to posit some 'group mind,' some organismic entity which is over and above its human components. The true explanation is simpler: the organization objective is, indirectly, a personal objective of all the participants. It is the means whereby their organizational activity is bound together to achieve a satisfaction of their own diverse personal motives. It is by employing workers to make shoes and by selling them that the entrepreneur makes his profit; it is by accepting the direction of the entrepreneur in the making of shoes that the employee earns his wage; and it is by buying the finished shoes that the customer obtains his satisfaction from the organization." (Simon, 1947: 17)

${ }^{105} \mathrm{Um}$ artigo relacionado a este tema é Simon (1955b), mas os trabalhos efetivamente foram realizados conjuntamente com Yuji Ijiri.
} 
Em segundo lugar, e mais importante, se a vertente mais explorada da estrutura teórica do trabalho de Simon é a individualista, as possibilidades de sua teoria não se esgotam aí, ela tem conexões teóricas importantes, potenciais e efetivas, do grupo para os indivíduos. Essas ligações aparecem algo emudecidas sob a forma de "contexto" - a organização é o contexto no qual o comportamento se dá - mas há de fato uma tensão no trabalho dele entre a explicação atomista e a lógica supra-individual da organização.

Com relação ao racionalismo as coisas não são muito diferentes. Há uma grande ênfase na explicação a partir da racionalidade em Simon mas, mais uma vez a cunha aparece através da figura da organização, em particular no importante conceito de identificação organizacional, que será discutido extensamente adiante. O mecanismo da identificação organizacional é um mecanismo motivacional, e não cognitivo, e o autor dá uma fundamentação evolucionária para sua existência. ${ }^{106}$

O principal motivo levantado por Simon para teorizar o comportamento em geral como racional é o de que, se o comportamento "não é completamente racional, ao menos em boa parte ele tem a intenção de racionalidade" (1976a: xxviii). Ele não alega que todo comportamento deva ser explicado com base na racionalidade, ao contrário, afirma que "claramente, uma ciência social madura terá que acomodar tanto o intelecto quanto o afeto". Porém, a partir de seu conceito de racionalidade restrita, ele tinha em vista "uma oscilação de retorno do pêndulo" em que "começaremos a interpretar como racionais e razoáveis muitas facetas do comportamento humano que agora explicamos em termos de afeto" (1957: 200).

Duncan Foley associa a vertente racionalista na economia, e sua tentativa de explicar os fenômenos econômicos a partir do comportamento racional individual, a uma filiação ideológica à tradição hobbesiana-lockeana da filosofia política. A racionalidade restrita e a procedimental não são poupadas:

This is not so much a question of adherence to any particular conception of rationality, but of taking rationality of individual behavior as the unquestioned starting point of economic analysis. As we shall see, mainstream economics has room for various concepts of rationality ('full rationality', 'bounded rationality', 'substantive rationality', 'procedural rationality', to list a few) and for vigorous debates over their relative merits. Grounding economics in the concept of rationality connects economics firmly to the Hobbesian-Lockean tradition of political philosophy, which purports to explain the

\footnotetext{
106 Embora essa base evolucionária, no final das contas, resulte ser um "auto-interesse esclarecido", como veremos adiante.
} 
political and economic organization of modern society as the necessary result of the interaction of naturally constituted rational individuals confronting each other as competitors for scarce resources. (Foley, 2003: 1-2)

Eu não refutaria a filiação de Simon a esta vertente racionalista, no entanto, as qualificações acima devem ser mantidas em mente. Em suma, o racionalismo e o individualismo metodológico se manifestam em Simon antes como tendência que como princípio.

\subsection{Nota sobre as obras utilizadas ${ }^{107}$}

Esta é uma seção dedicada aos meus procedimentos na realização deste trabalho. Devo discutir também as faltas que eu mesmo identifico nele, de maneira a deixar o leitor ciente delas. À primeira vista, talvez eu pudesse passar sem entrar nestas questões, uma vez que este se trata, primordialmente, de um trabalho de compilação. Contudo, tenho comigo bastante claro que a seleção realizada, e conseqüentemente o resultado do trabalho, foi bastante influenciada pelos caminhos que trilhei para abordar o autor. E esse é o motivo pelo qual julgo pertinente tratar desses caminhos aqui.

Talvez a falta mais importante seja que este trabalho se baseia, numa cifra otimista, em menos de $10 \%$ da produção de Simon, coisa que ele seguramente desaprovaria veementemente como "aquém dos padrões de evidência que ele mesmo atingiria" (Simon, 2001: 504). Meu resguardo quanto a isso se encontra na seleção que fiz dos trabalhos, e minha expectativa é a de que ela seja adequada no sentido de que nos dá uma amostra minimamente representativa do conjunto, nos temas que me dispus a tratar.

Em algum momento minhas atenções se voltaram para Simon, aparentemente com impulsos vindo de dois lados, interesse pelas discussões sobre racionalidade e meu desconforto com o construto do super-homem econômico neoclássico. Não muito tempo depois, sofri uma divergência: ao me deparar com os trabalhos de Simon sobre causalidade

\footnotetext{
${ }^{107}$ Faço referência nesta seção a alguns trabalhos que não li, mas apenas li a respeito. Faço isso no sentido de compartilhar, por incompleto que seja, o "mapa" que, ao final deste trabalho, tenho da obra de Simon, na intenção de dar alguma orientação a outros que porventura venham a estudá-lo.
} 
comecei a me indagar sobre o que constituía uma "explicação" e segui por um tempo esta linha. Seus artigos sobre causalidade, por sua vez, me levaram ao livro Models of man, social and rational (1957), no qual estavam compilados. Este livro me deu a primeira visão mais panorâmica do trabalho de $\operatorname{Simon}^{108} \mathrm{e}$, uma vez convencido de que a noção de causalidade dele não era o melhor caminho para seguir na direção original, voltei a pensar no trabalho do autor de maneira mais geral.

O livro de 1957 explorava alguns dos temas mais importantes que a dissertação de Ph.D. de Simon havia lhe legado. Tratava de outras coisas também, mas isso me levou a Administrative Behavior, o volume publicado da dissertação (Simon, 1947, 1976a). Este, por sua vez, conduziu, pelo assunto, a Organizations (March e Simon, 1958). Por volta deste momento também, li a autobiografia de Simon (1996a), e me deparei com o seguinte:

Around $1945, \ldots$ I revised my thesis, circulated it for comment, revised it again, found an editor willing to risk it (Donald Porter Geddes at Macmillan), and published it in 1947. It was built around two interrelated ideas that have been at the core of my whole intellectual activity: (1) human beings are able to achieve only a very bounded rationality, and (2) as one consequence of their cognitive limitations, they are prone to identifying to subgoals. I would not object to have my whole scientific output described as largely a gloss - a rather elaborate gloss, to be sure - on the pages of Administrative Behavior were these ideas are first set forth (especially pages 39-41, 204-12, and 240-44). (Simon, 1996a: 88)

Com essas coisas em vista eu já tinha então alguma estrutura. E, de fato, todo o meu trabalho se organiza a partir destes quatro livros. Tanto isso é verdade que: (1) encontraremos aqui uma ênfase no trabalho mais antigo de Simon, escrito antes de seu contato mais íntimo com os computadores; (2) a organização lógica dos tópicos ao longo do trabalho é quase cronológica e, (3) mesmo aquilo do trabalho mais tardio de Simon que é discutido, é tratado, em geral, com referência ao mais antigo. Estas características da dissertação não têm outra justificativa que não o fato de eu ter começado onde comecei, com aqueles livros em mente. $^{109}$ Não acho isso, que fique claro, um problema sério, mesmo olhando retrospectivamente. No entanto, acho importante mencionar que estas características foram menos fruto de uma decisão minha que dos caminhos trilhados.

\footnotetext{
108 O próprio autor (1996a: 165) afirma que o livro é "uma bom panorama de seu trabalho matemático e econométrico naquele momento".

109 Talvez tenha sido sorte, por exemplo, eu não ter olhado mais detidamente Models of bounded rationality (Simon, 1982a, 1982b) até recentemente. Os volumes são a coleção de artigos de Simon sobre economia (exceto os que tinham sido publicado em livros anteriormente) e possivelmente teriam me induzido a uma organização por tópicos, como a do livro, e me distanciado do resultado mais sintético a que cheguei aqui.
} 
Do ponto de vista de quem fez este trabalho que aqui está, no entanto, é fácil ver que esta não é a única maneira de organizar uma apresentação da obra de Simon, ainda que parcial, como esta. Há outras formas possíveis - e pertinentes, e interessantes - de fazê-lo. Uma, que me salta a vista, é ter como base a visão de Simon sobre a complexidade - de que muito do mundo (se não tudo) se organiza como sistemas hierárquicos - o que nos levaria a The sciences of the artificial (Simon, 1996b). ${ }^{110} \mathrm{E}$ eu, aqui, apenas resvalo nele em alguns momentos, sem apresentá-lo de forma mais sistemática.

Outra forma seria organizar a apresentação a partir do trabalho mais tardio de Simon, o que seria provavelmente mais difícil, em função da maior diversidade temática, mas potencialmente interessante. Exigiria também uma dedicação mais consistente ao trabalho de Simon na área de ciência cognitiva, a começar pelo tratado sobre o assunto dele e de Allen Newell (Newell e Simon, 1972). ${ }^{111}$

De qualquer maneira, estes não foram os caminhos que tomei, e foi a partir dos quatro livros referidos que comecei a ler de maneira mais orquestrada a obra de Simon. Eles forneceram os elos iniciais, mas também não foram os únicos critérios. Dois outros pelo menos me parecem importantes: procurei ler as conferências proferidas por Simon que foram publicadas tendo em vista que, tipicamente, estes são momentos em que o autor procura organizar a própria obra de pontos de vista mais gerais; procurei também ler textos de Simon orientados a diferentes públicos, ${ }^{112}$ o que se mostrou proveitoso no sentido de que determinados pontos da teoria apareciam mais claros em um ou outro jargão. Dentre estas conferências An empirically based microeconomics (Simon, 1997a) me deu uma amostra do trabalho mais recente dele voltado à economia e me orientou neste âmbito. ${ }^{113}$

Há também as omissões, estas mais deliberadas e já um pouco menos dependentes da trajetória. Trabalhos de disciplina no primeiro semestre do ano passado me levaram a estudar um pouco da visão de Simon sobre complexidade e outro tanto das ironias da história da

\footnotetext{
${ }^{110}$ Algo já foi feito neste sentido por Sent (2001a), mas creio que ainda há o que explorar.

111 Teria sido apropriado lê-lo mesmo para este trabalho, uma vez que o livro é bastante importante na carreira de Simon. No entanto, sua aridez me afastou dele: o grosso do livro constitui-se de programas de computador (a linguagem na qual apresentam sua teoria) e discussões sobre eles. Models of thought (Simon, 1979c, 1989) seria, creio, o próximo da lista.

${ }^{112}$ Como se sabe ele atuou em diferentes disciplinas, que constituíam públicos distintos.

${ }^{113}$ Simon $(1960,1983,1996 b)$ também se tratam de conferências publicadas.
} 
hipótese de expectativas racionais, e do envolvimento de Simon com ela. ${ }^{114}$ No entanto, não achei que era o caso de desenvolver a fundo nenhum destes temas aqui. Ando (1979) e Baumol (1979), ao tratar das contribuições de Simon para a economia, ${ }^{115}$ apontam principalmente para o trabalho dele sobre racionalidade restrita, mas discutem outras das quais eu não trato. Entre elas encontram-se: (1) seus trabalhos sobre quase-decomponibilidade (near decomposability) que, em termos gerais, tratam da formalização da visão dele sobre a complexidade e sobre a estrutura hierárquica dos sistemas (Ando, Fisher e Simon, 1963). Um resultado interessante deste trabalho é a formalização das condições nas quais uma análise de equilíbrio parcial e o uso de variáveis agregadas podem ser justificados (Simon e Ando, 1961). Relacionados a este tema, também, estão os trabalhos do autor sobre causalidade e o problema da identificação (Simon, 1952, 1953a, 1954a); e (2) suas contribuições à economia matemática, entre eles o teorema da certeza equivalente e o teorema Hawkins-Simon. O teorema da certeza equivalente demonstra que, quando num problema de programação dinâmica, a função maximizada pode ser expressa na forma quadrática, as distribuições de probabilidades podem ser substituídas pelos seus primeiros momentos (valor esperado) (Simon, 1956b). Este teorema surgiu no contexto do projeto de aplicação de pesquisa operacional ao planejamento da produção, com Holt, Modigliani e Muth. O teorema HawkinsSimon especifica as condições em que sistemas de equações lineares terão soluções estacionárias com todas as variáveis positivas (Hawkins e Simon, 1949).

Estes e outros tópicos econômicos que Simon pesquisou sistematicamente - como suas discussões sobre políticas públicas (relacionado ao seu trabalho na área de administração pública), seus trabalhos sobre o impacto do avanço tecnológico sobre a economia, sobre economia da informação ou sobre a distribuição do tamanho das firmas - não serão discutidos diretamente nesta dissertação. No entanto, muitos destes tópicos se relacionam, e podem ser melhor entendidos, a partir do quadro teórico mais sintético que apresento aqui. Ao identificar a teoria comportamental de Simon como o núcleo de sua obra - em geral e para a economia

\footnotetext{
${ }^{114}$ A história é bastante curiosa e, só para instigar o leitor, conto que John Muth foi aluno da GSIA no Carnegie Tech e que trabalhava, na época do famoso artigo, num grupo de pesquisa com Simon - e também com Charles Holt e Franco Modigliani. O projeto deles era financiado pela marinha americana e visava criar e aplicar métodos matemáticos (pesquisa operacional) ao planejamento da produção (Holt, Modigliani, Muth e Simon, 1960). O artigo de Muth na Econometrica foi realizado sob o financiamento do mesmo projeto de pesquisa (Muth, 1961), e foi deste projeto que surgiu a inspiração de Muth para a hipótese (Sent, 1997: 324-325). Lucas, Sargent e Rapping também passaram pela GSIA em algum momento dos anos 1960.

${ }_{115} \mathrm{O}$ artigo de Ando é bastante superior ao de Baumol.
} 
em particular - me sinto justificado nas omissões que faço e na ênfase da apresentação desta teoria aqui.

As direções tomadas na contextualização histórica que faço da obra de Simon nas primeiras seções deste capítulo tiveram sua origem em algumas leituras que fiz por outros motivos, em particular Mills (1959) e Horowitz (1969). Mills identificava e criticava algumas transformações sofridas pela disciplina da sociologia a partir de meados do século XX e Horowitz colocava em questão os usos da atividade científica no contexto da Guerra Fria. Não pude deixar de relacionar a figura de Simon ao contexto geral dos eventos discutidos nestes trabalhos. A pesquisa histórica acabou criando vida própria e, em função disso, a contextualização resultou (assumidamente) hipertrofiada com relação aos objetivos propostos. E a mantive assim porque o resultado se mostrou interessante por si só.

Enfim, creio que isso é tudo de "meta-dissertativo" que eu tenho a dizer.

\subsection{Contexto}

Neste capítulo, tratamos de fornecer uma situação para a apresentação da obra de Simon tal como proposta na introdução. Desenvolvemos elementos de contexto em três planos. O primeiro, e mais importante, o plano histórico e biográfico. O segundo, um recorte metodológico breve da obra de Simon. O terceiro, uma discussão sobre os procedimentos deste estudo. Acredito que apenas o primeiro reclama algum resumo.

$\mathrm{Na}$ contextualização histórica do trabalho de Simon exploramos alguns temas, marco aqui os mais importantes. Primeiro, tratamos do "regime da Segunda Guerra Mundial" surgido em torno da confluência entre as empreitadas científica e militar durante a Segunda Guerra e algumas de suas conseqüências mais gerais. Em segundo lugar, discutimos a importância deste regime para a carreira de Simon, em particular a disponibilidade do computador, a partir de meados da década de 1950, para sua pesquisa. Em terceiro lugar, identificamos e analisamos como importante manifestação desse regime a "pesquisa operacional" e foram traçadas algumas de suas implicações para a economia em particular e, de maneira mais vaga, para as ciências sociais em geral. 
Do ponto de vista do restante do trabalho, acho particularmente importante guardar dois pontos desta discussão. Primeiro, é bom ter em vista - deve facilitar o entendimento - as mudanças na agenda de pesquisa de Simon em meados dos anos 1950 e os novos conceitos que vão surgindo a partir daí. Segundo, queria ressaltar, talvez não tenha feito isso o suficiente, a centralidade do computador nestes eventos que viemos discutindo, tanto para Simon quanto para o processo histórico mais geral. 


\section{Racionalidade}

Simon aponta para uma "esquizofrenia aguda [das ciências sociais] em seu tratamento da racionalidade" (1976a: xxvi-xxvii, ver também 1957: 1). De um lado os economistas atribuem ao homem econômico uma racionalidade absoluta e onisciente: as alternativas de comportamento são conhecidas em sua totalidade, as conseqüências de cada uma delas também são, estocástica ou deterministicamente, conhecidas e preferências consistentes e completas juntamente com uma capacidade computacional irrestrita permitem a ordenação das alternativas e a seleção da preferida entre todas as possíveis. No outro extremo, afirma ele, encontramos, na psicologia social, tentativas de reduzir a cognição ao afeto e de demonstrar que os homens não são, nem de perto, tão racionais quanto gostam de se imaginar.

Do ponto de vista de nosso estudo não importa tanto se a esquizofrenia, de 1976 até o momento, foi ou tem sido "tratada" entre os psicólogos sociais, mas mais o fato de que a posição do mainstream econômico no espectro dos tratamentos da racionalidade continua extremada.

Nesse sentido, o conceito de racionalidade restrita de Simon é uma tentativa de mediar entre os aspectos racionais do comportamento humano e uma descrição realista deste comportamento, que apresenta muito pouco dos poderes atribuídos ao homem econômico. É importante notar que, apesar dele ressaltar as restrições à racionalidade, seu movimento corresponde a uma extensão das possibilidades do conceito, pois o conceito de racionalidade restrita permite tratar como racional uma classe muito maior de comportamentos. ${ }^{116}$ Mas por que esta ênfase nos aspectos racionais do comportamento? O que a sustenta é a percepção de Simon de que, em geral, muito do comportamento humano tem, ao menos, a intenção de racionalidade - é orientado a objetivos, sendo muitas vezes eficaz em atingi-los. Nesta passagem, em especial, a noção de racionalidade é dissociada (volta a ser dissociada) da idéia de onisciência, desfazendo a ligação entre estes conceitos, distintos, tal como encontrada na

\footnotetext{
${ }^{116}$ A transitividade é apenas o exemplo mais óbvio do ponto de vista do economista. Escolhas não transitivas podem ter sido feitas racionalmente por um agente restritamente racional. No jargão, o conceito de racionalidade de Simon é menos restritivo.
} 
hiperracionalidade neoclássica. Como resultado, a psicologia não pode ser deixada de fora da teoria (Simon, 1976a: xxviii).

Simon sempre questiona os méritos descritivos da teoria econômica tradicional, mas sua posição sobre o caráter normativo da teoria neoclássica é mais ambígua. Podemos ter uma amostra disso a partir dos seguintes trechos publicados num período de tempo relativamente curto:

Recent developments in economics, and particularly in the theory of the business firm, have raised great doubts as to whether this schematized model of economic man provides a suitable foundation on which to erect a theory - whether it be a theory of how firms $d o$ behave, or of how they 'should' rationally behave. (Simon, 1955a: 241)

One can hardly take exception to these requirements [made to the economic man] in a normative model - a model that tells people how they ought to choose. For if the if the rational man lacked the information, he might have chosen differently 'if only he had known'. (March e Simon, 1958: 138)

O que poderia ser dito para esclarecer esta situação? O modelo da teoria econômica tradicional talvez pudesse ser tomado como normativo se pensado como uma espécie de "referência", no entanto, na prática ele fornece poucas pistas de como proceder. Isto acontece porque, de fato, a questão de eficiência sempre se coloca ao decisor de forma relativa (Simon, 1947: 181): Entre as alternativas consideradas qual a mais eficiente? Ela nunca aparece na forma: Qual é a alternativa mais eficiente? Neste sentido, a teoria baseada no ótimo não é uma boa teoria normativa porque não provê regras de conduta através das quais se poderia, ao menos, melhorar a eficiência das decisões. Todavia, isso não quer dizer que não se deva tentar caminhar em direção ao "ótimo", mesmo que não se saiba jamais o quanto falta para chegar lá, com soluções que são, só, melhores que as outras. "Attainment of objectives is always a matter of degree." (Simon, 1947: 177).

\subsection{Comportamento racional}

Esta seção lida com a definição lógica de racionalidade. Tal como Simon a discute, esta definição corresponde à racionalidade objetiva, ou onisciente, ou à hiperracionalidade

\footnotetext{
${ }^{117}$ E também: "It may be said in defense of the theory of games and statistical decision theory that they are to be regarded not as descriptions of human choice but as normative theories for the guidance of rational decision. Even this defense seems to me untenable, but I shall not pursue the issue here." (Simon, 1957: 203)
} 
encontrada na teoria econômica neoclássica. $\mathrm{Na}$ opinião dele, no entanto, dela não decorre uma descrição do comportamento humano tal qual o encontrado na realidade, e este tópico será tratado na próxima seção.

\subsubsection{Pressupostos lógicos do conceito}

Simon (1947: 45) faz distinção entre os elementos "factuais" e os "de valor" em uma decisão, sendo que toda decisão envolve ambos os tipos de elementos. A distinção é, tal como feita por ele, puramente teórica, na medida em que ambos os aspectos - factual e de valor - na prática se misturam, necessariamente, em qualquer decisão. Cada decisão envolve a seleção de um objetivo e de um comportamento relevante ao seu cumprimento, cada objetivo por sua vez pode ser instrumental para um objetivo mais amplo. Como tipos ideais, na medida em que esta seleção trate de objetivos "finais" teremos "julgamentos de valor", e na medida em que trate da forma de levar estes objetivos a cabo teremos "julgamentos de fato" (Simon, 1947: 4$5)$.

Proposições factuais são passíveis de comparação com a experiência, com o mundo tal qual observado e sobre o seu funcionamento. Elas podem, portanto, ser julgadas com relação à sua veracidade. Decisões, no entanto, vão além de proposições factuais, pois elas envolvem a seleção de um estado de coisas futuro preferido, em detrimento de outros. Têm portanto um conteúdo ético intrínseco, além do factual. Proposições éticas não podem ser testadas nem empiricamente nem racionalmente, pois não podem ser obtidas apenas de proposições factuais e nem ser comparadas diretamente com a experiência. Decisões têm uma função imperativa, no sentido de que incluem julgamentos do tipo: “deveria ser", "é preferível”, "é desejável”; e portanto não podem ser objetivamente descritas como corretas ou incorretas (Simon, 1947: 46).

Como avaliar decisões então? Segundo Simon, se elas não podem ser avaliadas de maneira absoluta, o seu conteúdo factual pode ser avaliado com relação à medida em que é conducente do conteúdo de valor da decisão, dos objetivos a que está voltada. Uma decisão é "correta" ou "incorreta", portanto, apenas de maneira relativa: relativamente a uma finalidade dada. Ela é correta se seleciona as medidas adequadas para atingir os propósitos estipulados. Nas palavras do autor:

Hence, there is one sense in which the correctness of his decisions can be judged: it is a purely factual question whether the measures he takes in order to accomplish his aim are 
appropriate measures. It is not a factual question whether the aim itself is correct or not, except in so far as this aim is connected, by an 'in order', to further aims.

Decisions can always be evaluated in this relative sense - it can be determined whether they are correct, given the objective at which they are aimed - but a change in objectives implies a change in evaluation. Strictly speaking, it is not the decision itself which is evaluated, but a purely factual relationship that is asserted between the decision and its aims. (Simon, 1947: 48-49)

A origem destas definições é, de acordo com o próprio autor, a escola filosófica que discutimos acima: o positivismo lógico. ${ }^{118}$

\subsubsection{Comportamento (objetivamente) racional}

Este item se dedica a discutir o que estaria envolvido na efetivação de um comportamento racional tal como o preconizado pela definição dada acima se levada às suas conseqüências lógicas - de um comportamento objetivamente racional. Como foi comentado acima, a idéia de racionalidade objetiva, também chamada de hiperracionalidade, mescla duas hipóteses comportamentais distintas, a de racionalidade e a de onisciência, pois, em última instância, avaliar "a relação factual que é afirmada entre a decisão e seus objetivos" exige estas características. ${ }^{119}$

Na definição que Simon apresenta, uma escolha é uma seleção de uma, dentre inúmeras alternativas comportamentais possíveis (ações fisicamente possíveis), para ser levada a cabo. Todo comportamento envolve uma seleção deste tipo, consciente ou inconsciente (Simon, 1947: 3-4). Uma decisão é o processo através do qual esta seleção é efetuada.

A relação postulada por Simon entre escolha e comportamento é quase unívoca. Dado que, como ele supõe, a seleção é feita entre alternativas "fisicamente possíveis", uma vez tomada a decisão aparentemente não há empecilhos para a sua realização. O caminho que leva à ação racional é o seguinte: propósitos ou motivações $\rightarrow$ escolha $\rightarrow$ ação. Se, como veremos adiante, a relação entre os propósitos e a escolha é problematizada por ele, a relação entre a

\footnotetext{
118 Ao introduzir o capítulo Simon se coloca: “...[T]he conclusions reached by a particular school of modern philosophy - logical positivism - will be accepted as a starting point, and their implications for the theory of decisions examined." (1947: 45)

119 O motivo pelo qual exige não é óbvio, no entanto. Mas para ter a dimensão da coisa pense a respeito do seguinte: é a hipótese de onisciência que permite o isolamento do "julgamento de fato" do "julgamento de valor" na análise, falhas de informação podem reintroduzir elementos de valor na questão "factual".
} 
escolha e a ação nunca o é. Este isolamento é garantido, também, pela consideração, no próprio processo de escolha, das conseqüências da ação, e portanto também da relação entre escolha e ação. Logo, levar uma escolha a cabo numa ação só falha na medida em que as conseqüências não são corretamente consideradas no processo de escolha. Como resultado, a teoria comportamental de Simon é reduzida a uma teoria da escolha ou da decisão. Isso é sugerido pela passagem abaixo:

It should be made clear that actual events are determined by choice among on-the-spot alternatives for immediate behavior. In a strict sense, a decision can influence the future in only two ways: (1) present behavior, determined by this decision, may limit future possibilities, and (2) future decisions may be guided to a greater or lesser degree by the present decision. It is from this possibility of influencing future choice by present decisions that the idea of an interconnected plexus of decisions derive. (Simon, 1947: 97, ênfase minha)

A avaliação objetiva de uma decisão deve ser feita em termos das alternativas comportamentais e de suas conseqüências. Em termos de alternativas e conseqüências a tomada de decisão objetivamente racional envolve três etapas: (1) a listagem de todas as possíveis estratégias alternativas de comportamento, (2) a enumeração de todas as conseqüências que se seguem a cada uma delas, quer na forma de distribuições de probabilidade ou de eventos específicos, e (3) a comparação entre os conjuntos de conseqüências que se seguem à cada alternativa em termos de uma escala de valores abrangente (Simon, 1947: 67; March e Simon, 1958: 137-138). É neste sentido que o comportamento objetivamente racional pressupõe a onisciência. A semelhança com a teoria econômica neoclássica não é casual, ela é de fato a origem do constructo. Ela postula um ambiente de decisão onde: as alternativas são dadas; onde a cada uma delas está associado, probabilística ou deterministicamente, um conjunto de conseqüências; e uma, também dada, ordenação de preferências estável e não ambígua sobre estes conjuntos. A diferença está em que, se o modelo neoclássico se pretende descritivo, ou ao menos preditivo, do comportamento, Simon afirma apenas que ele o seria, se os homens fossem (objetivamente) racionais (Simon, 1947: 182). Da perspectiva da teoria comportamental de Simon, portanto, a racionalidade objetiva tem um status lógico, e não descritivo.

A ponte entre as alternativas e as conseqüências é feita pelo conhecimento. $\mathrm{O}$ conhecimento seleciona, de um conjunto de todos os possíveis eventos conseguintes a uma decisão, um subconjunto deste contendo as conseqüências associadas a cada estratégia alternativa. Essa associação é feita sob a forma de expectativas, uma vez que se trata de 
conseqüências futuras. A racionalidade objetiva depende, portanto, da precisão das previsões que se configuram nas expectativas para se efetivar. O processo final de decisão é o de valoração, onde são determinadas as preferências sobre as conseqüências e a alternativa que produz o conjunto preferido de conseqüências é selecionada.

Vimos, portanto, que a racionalidade do comportamento consiste na seleção de uma alternativa preferida relativamente a algum sistema de valores. Isto não implica, no entanto que este processo seja deliberado ou consciente. Além disso, do ponto de vista de que sistema de valores ela deve ser considerada? A solução para estes dilemas é qualificar a racionalidade. Uma decisão será objetivamente racional, conforme já usado acima, na medida em que, de fato (não apenas relativamente às expectativas), maximize os valores dados numa dada situação. Será conscientemente ou deliberadamente racional na medida em que o ajustamento entre meios e fins seja consciente ou deliberado. Será organizacionalmente racional se voltada aos objetivos da organização, e pessoalmente racional se voltada aos objetivos pessoais de um indivíduo (Simon, 1947: 77).

\subsubsection{Comportamento racional}

O comportamento, tal como podemos observá-lo, é subjetivamente racional. Uma decisão é subjetivamente racional na medida em que se adapta ao ambiente subjetivo de decisão, ${ }^{120}$ um conjunto de premissas relevantes tomadas como dadas, do ponto de vista do decisor individual. É neste sentido, na obra de Simon, que o comportamento humano é racional. Além de ser subjetivamente racional, no que se refere às suas possibilidades, o comportamento humano em geral tem, no que se refere às suas pretensões, às suas disposições, a intenção de racionalidade. É isso que justifica, na obra de Simon, a ênfase nos aspectos racionais do comportamento humano, e a tentativa de teorizá-lo como tal.

Conforme afirmado acima, uma decisão só pode ser racional se for propositada, motivada, se tiver objetivos. De fato, os objetivos devem constar entre as "premissas relevantes". Em particular, considerações de eficiência devem estar envolvidas. Como o comportamento racional envolve sempre a comparação entre os meios alternativos com

\footnotetext{
${ }^{120}$ Desenvolverei melhor este conceito na próxima seção.
} 
relação aos fins visados, a eficiência - seleção do maior valor numa situação dada, com recursos escassos - tem de ser um critério, normativo, de orientação à decisão racional.

A distância que existe entre o comportamento objetivamente racional e o comportamento (subjetivamente) racional reside em dois aspectos. Primeiro, na diferença entre estes dois ambientes de escolha. A principal diferença aqui reside no conhecimento conhecimento de alternativas e de conseqüências - a onisciência é abandonada porque não caracteriza o ambiente subjetivo de escolha. Segundo, na adaptabilidade do comportamento no interior do ambiente de escolha. Na prática, ambos os aspectos sempre se misturam. Por um lado, a razão pela qual os ambientes objetivo e subjetivo são diferentes é justamente que as capacidades cognitivas dos agentes são insuficientes para lidar com o ambiente objetivo. Por outro, em geral, o ambiente subjetivo é constituído de tal maneira, é suficientemente simples, que a adaptabilidade em seu interior não é exatamente problemática.

\subsection{Racionalidade restrita}

Vimos na seção anterior as demandas que seriam colocadas sobre o agente para uma tomada de decisão objetivamente racional. Veremos agora os argumentos de Simon sobre o porquê, e em que medida, o comportamento humano se distancia, de fato, deste padrão. Trataremos nesta seção da caracterização psicológica humana feita pelo autor e de suas conseqüências imediatas para o comportamento. A influência exercida sobre este pelo ambiente organizacional será discutida no próximo capítulo.

\subsubsection{Restrições à racionalidade}

Simon argumenta que o homem não se comporta de forma objetivamente racional não porque não queira, mas porque não consegue. Suas capacidades cognitivas e computacionais são bastante limitadas quando comparadas com a complexidade do mundo à sua volta. A partir desta percepção ele avança o "princípio da racionalidade restrita":

The capacity of the human mind for formulating and solving complex problems is very small compared with the size of the problems whose solution is required for objectively 
rational behavior in the real world - or even for a reasonable approximation to such objective rationality. (Simon, 1957: 198) ${ }^{121}$

No processo decisório real as demandas para a racionalidade objetiva não são atendidas pois: (1) A racionalidade objetiva exige um conhecimento completo sobre as conseqüências que se seguem a cada alternativa, e isto por sua vez exige uma antecipação perfeita delas quer na forma de eventos específicos ou na forma de distribuição de probabilidades - no que diz respeito a todos os detalhes, a tempos e lugares infinitamente distantes, e um conhecimento perfeito sobre a situação presente. No entanto, na realidade este conhecimento é sempre muito limitado e fragmentário; (2) A racionalidade objetiva exige uma antecipação perfeita dos valores atribuídos às conseqüências, na realidade, como estas conseqüências se encontram no futuro a imaginação preenche o espaço deixado pela falta de experimentação na valoração; (3) A racionalidade objetiva exige que todas as alternativas de comportamento possíveis sejam consideradas, com efeito, apenas algumas poucas alternativas são vislumbradas (Simon, 1947: 81). Estes descompassos evidenciam que, na opinião de Simon, por trás das principais dificuldades do conceito de racionalidade objetiva está o pressuposto "adicional" da onisciência.

O comportamento que podemos observar entre as pessoas não exibe a racionalidade global, tal como descrita no modelo neoclássico, mas antes possui a feição de uma bricolagem ou de um mosaico. Partes pequenas da figura exibem uma coerência interna própria, mas elas se interconectam imperfeitamente ao compor a figura mais ampla. Simon chama de integração do comportamento ao grau em que a composição entre as partes é coerente do ponto de vista da figura mais geral, ao quão racionais são elas relativamente aos objetivos mais gerais. Nas palavras do autor:

Real behavior, even that which is ordinarily thought of as 'rational' possesses many elements of disconnectedness not present in this idealized picture. If behavior is viewed over a stretch of time it exhibits a mosaic character. Each piece of the pattern is integrated with others by their orientation to a common purpose; but these purposes shift from time to time with shifts in knowledge and attention, and are held together in only slight measure by any conception of an over-all criterion of choice. It might be said that behavior reveals 'segments' of rationality - that behavior shows rational organization within each segment, but the segments themselves have no very strong interconnections. (Simon, 1947: 80-81)

\footnotetext{
${ }^{121}$ Foi neste livro, Models of man, social and rational, que o termo bounded rationality foi introduzido, embora o conceito por trás dele já existisse anteriormente (Klaes e Sent, 2002).
} 
Mas, podemos perguntar, estamos mais perto dos pixels da tela do computador ou das pastilhas de um mosaico bizantino ${ }^{122}$ A resposta mais correta é: depende, mas no geral a imagem das pastilhas é mais apropriada, pois a aproximação à racionalidade objetiva é extremamente grosseira e simplificada (Simon, 1955a: 243).

Na seção anterior foi dito que uma escolha subjetivamente racional se dá com relação a um ambiente subjetivo de escolha. Este ambiente pode ser analisado como um conjunto de premissas, e a decisão como um processo de tirar conclusões dessas premissas. As mesmas são tomadas como os dados da decisão, como explica Simon em diferentes trechos de sua obra:

Action is goal-oriented and adaptive. But because of its approximating and fragmentary character, only a few elements of the system are adaptive at any one time; the remainder are, at least in the short run, 'givens'. (March e Simon, 1958: 169)

Individual choice takes place in an environment of 'givens' - premises that are accepted by the subject as bases for his choice; and behavior is adaptive only within the limits set by these 'givens'. (Simon, 1947: 79)

...[I]t is necessary to keep constantly in mind the idea of a decision as a conclusion drawn from a set of premises - value premises, and factual premises. (Simon, 1947: 123)

A premissa, portanto, deve ser usada como a unidade básica de análise na tomada de decisão (Simon, 1976a: xii), sendo uma unidade mais fina que as usualmente utilizadas por outras teorias, como a "ação", ou a "decisão". Como vimos na citação acima as premissas podem ser divididas em premissas de valor ou premissas de fato. Uma outra classificação delas pode ser feita entre: (1) valores e objetivos; (2) relações entre ações e seus resultados; (3) as alternativas consideradas.

It includes: (a) values or goals: criteria that are applied to determine which courses of action are preferred among those considered; (b) relations between actions and their outcomes: i.e. beliefs, perceptions, and expectations as to the consequences that will follow from one course of action or another; and (c) alternatives: possible courses of action. (March e Simon, 1958: 11) ${ }^{123}$

A classificação é análoga à que fizemos para a escolha objetivamente racional, com a diferença de que aqui as premissas que constam em cada um destes elementos da escolha são

\footnotetext{
${ }^{122}$ Uma analogia semelhante poderia ser feita no tempo, ao invés do espaço, entre os filmes dos primórdios do cinema e os filmes atuais.

${ }^{123}$ Faço alguma distorção terminológica nesta citação. Esta classificação de March e Simon se refere ao conteúdo da "memória", enquanto separada do ambiente externo. No entanto ela é bastante apropriada, e o uso que faço dela aqui é consistente com o uso que Simon faz do conceito de premissa em outros lugares.
} 
apenas aquelas consideradas (consciente ou inconscientemente) pelo decisor no processo de decisão, pois elas descrevem o ambiente de escolha tal como ele o percebe. ${ }^{124}$ É neste sentido que podemos utilizar-nos da terminologia "ambiente subjetivo de escolha", que já não envolve onisciência, em contraposição a um "ambiente objetivo de escolha".

Mas, dado que a decisão é adaptativa apenas no interior de seu ambiente de escolha, se o ambiente subjetivo se equalizasse ao objetivo a decisão subjetiva poderia ser objetivamente racional. No entanto, é justamente a diferença radical entre esses dois ambientes de escolha o principal fator responsável pela distância entre o comportamento real e o objetivamente racional. O ambiente subjetivo é infinitamente mais simples do que o ambiente objetivo. E a limitação do ambiente subjetivo de escolha restringe a racionalidade.

Assim sendo, Simon parte para perguntar então quais são os determinantes deste ambiente subjetivo de escolha, em outras palavras, quais são as restrições à racionalidade. Esta é uma das perguntas centrais, na opinião do autor, que uma teoria administrativa ou uma teoria das organizações deve tentar responder. Ela aparece em diversas roupagens: como "a fronteira entre os aspectos racionais e não racionais do comportamento humano social" (Simon, 1976a: xxviii); ou "os limites para a realização de objetivos que são, de fato, limites da flexibilidade e adaptabilidade de indivíduos na busca de seus objetivos" (Simon, 1957: 199).

Os determinantes do ambiente de escolha se encaixam em duas classes principais: as propriedades psicológicas (cognitivas) ${ }^{125}$ do agente, e o ambiente social (ou organizacional) que o cerca e influencia. Conseqüentemente, estes aspectos não podem ficar de fora de uma teoria comportamental, não podem ser tomados como exógenos, mas têm que ser explicados pela teoria (March e Simon, 1958: 139; e Simon, 1957: 199).

\footnotetext{
${ }^{124}$ Na terminologia de March e Simon (1958) trata-se do "conjunto evocado da memória".

${ }^{125}$ Não farei ao longo deste estudo uma diferenciação consistente entre o "psicológico" e o "cognitivo". Como discutiremos brevemente adiante, a ciência cognitiva trata dos fenômenos da cognição e é uma área da psicologia. A cognição é parte dos processos psicológicos, mas estes não se reduzem àquela. Outros aspectos psicológicos seriam os afetivos, emotivos ou impulsivos, por exemplo. Mas em função das minhas limitações no assunto e da ênfase do trabalho de Simon estar na ciência cognitiva não tenho como fazer a distinção apropriadamente. Assim, aqui "psicológico" será quase sinônimo de "cognitivo".
} 
A descrição psicológica do homem feita por March e Simon (1958) é a de um organismo de capacidades pequenas quando comparadas com a complexidade dos problemas com que lida. Uma pessoa consegue dar atenção apenas a uma ou poucas coisas por vez, e, num dado momento, consegue lidar com um volume bastante limitado de informação. Ela responde a estímulos externos, e estes têm uma influência grande no conteúdo do ambiente de decisão, em particular, estes podem, numa gama grande de casos, ser tratados como a origem da motivação da ação.

This, then, is the general picture of the human organism that we will use to analyze organizational behavior. It is a picture of a choosing, decision-making, problem-solving organism that can do only one or a few things at a time, and that can attend to only a small part of the information recorded in its memory and presented by the environment. We shall see that these particular characteristics of the human organism are basic to some of the salient characteristics of human behavior in organizations. (March e Simon, 1958: 11)

Além disso, esta descrição permite encampar como racionais comportamentos que uma teoria de racionalidade global descartaria como irracionais ou não racionais (Simon, 1957: 200), chegando mais próxima da noção de racionalidade de senso comum. Neste sentido, como comentei acima, a teoria de Simon significa uma expansão do conceito de racionalidade, uma vez que a capacidade de explicar diferentes comportamentos como racionais é incrementada.

Olhar o modelo tradicional do ponto de vista das premissas fixas que ele assume é um exercício interessante. Simon (1955a: 242) nota que, em modelos de escolha racional, normalmente o conjunto de alternativas para a escolha, a relação entre as alternativas e seus respectivos payoffs, e a ordenação entre os diferentes payoffs são todos tomados como fixos, o tomador de decisão opera sobre (computa, controla) tudo o mais, menos estes. O estratagema lógico comumente mobilizado para admiti-los como dados é dizer que estas são características do ambiente, externas ao agente e, portanto, objetivas. (Exceto, é claro, a ordenação). Eventualmente, todavia, admite-se que o agente pode ser ignorante a respeito do futuro, então assume-se que a relação entre as alternativas e as conseqüências não é conhecida de forma determinística, mas apenas até o conhecimento de uma função de distribuição de probabilidade no domínio das conseqüências. Simon (1957: 198) então pergunta: "Mas se admitimos que o homem racional pode ser ignorante a respeito do futuro, que sua racionalidade não implica onisciência, que outros limites podemos colocar sobre ele?". Mais especificamente, se ele porventura é ignorante a respeito das alternativas possíveis, se o 
conjunto "fixo" que o tomador de decisão considera, é um subconjunto próprio (está contido mas não contém) do conjunto das alternativas possíveis, por que não admitir que o próprio agente não pode controlar o conjunto de alternativas consideradas? E, se assim fizermos, como ele busca novas alternativas? Se ele não tem toda a informação, como ele se informa? E por que não mais? Por que não levar em consideração, além do ambiente, as características cognitivas, e limites, do próprio agente?

\subsubsection{Mecanismos simplificadores da decisão}

Simon argumenta que a capacidade intelectual limitada para lidar com os problemas em sua plenitude faz com que as pessoas adotem uma série de mecanismos simplificadores da decisão. Entender estes mecanismos é fundamental para entender o comportamento humano racional tal como ele se efetiva na realidade, pois esta é forma usada pelas pessoas para reduzir um problema complexo a dimensões tratáveis. Segundo o autor:

...[T]he definition of the situation represents a simplified, screened, and biassed model of the objective situation, and filtering affects all the 'givens' that enter into the decision process: knowledge or assumptions about future events; knowledge of sets of alternatives available for action; knowledge of consequences attached to alternatives; goals and values. (March e Simon, 1958: 154-155)

Trataremos de três destes mecanismos: satisfazimento, modelos simplificados da realidade e a fatoração. Como veremos, estes mecanismos estão relacionados entre si.

\subsubsection{Satisfazimento ${ }^{126}$}

A principal simplificação no processo de escolha introduzida por Simon é a idéia de que os decisores, ao invés de procurar maximizar os valores numa dada escolha, visam o satisfazimento, procuram alternativas que são boas o suficiente de acordo com algum padrão estabelecido (Simon, 1956a: 261; 1957: 205; 1976a: xxix; March e Simon, 1958: 140-141). E

\footnotetext{
${ }^{126}$ Como comentei na nota 3, adoto a tradução, que considero apropriada, de Silveira (1983) para o termo satisficing. Sugiro ainda uma verbalização do termo. Para tanto, cabe lembrar que satisfice é um sinônimo de satisfy num antigo dialeto inglês: "The term 'satisfice', which appears in the Oxford English Dictionary as a Northumbrian synonym for 'satisfy', was borrowed for this new use by H.A. Simon (1956), in 'Rational Choice and the Structure of the Environment'." (Simon, 1987: 243). Proponho procedimento análogo no português, recorrendo a um dos nossos fornecedores lingüísticos locais: o latim. O Dicionário Eletrônico Houaiss da Lingua Portuguesa, indica uma grafia antiga para satisfazer: "satisfacer", bastante próxima da origem etimológica latina da palavra: satisfacere. "Conjugando" então, para satisfices, satisfice e satisficed adoto respectivamente: satisface, satisfacem, satisfazido.
} 
assim o fazem porque não têm a sagacidade para maximizar, na grande maioria dos casos suas capacidades cognitivas e computacionais não o permitem.

O decisor otimiza se escolhe uma alternativa que é a melhor de acordo com algum critério que permita comparar todas as alternativas entre si. O decisor satisface se escolhe uma alternativa que atende ou excede um conjunto de critérios mínimos de aceitabilidade, se escolhe uma alternativa satisfatória. Otimizar requer processos diversas ordens de magnitude mais complexos que aqueles necessários para satisfacer (March e Simon, 1958: 140). O exemplo dado é eloqüente: a diferença entre os processos seria como a diferença entre procurar a agulha mais afiada do palheiro e encontrar no palheiro uma agulha com que fosse possível costurar. Com esta simplificação a resolução do problema deixa de depender do tamanho do palheiro, e passa a depender apenas da densidade de agulhas no palheiro. No entanto, a alternativa satisfatória não é em nenhum sentido a melhor e nem tampouco a única. Aqui, portanto, os argumentos marginalistas tradicionais são abandonados.

A conseqüência desta simplificação é a de que um decisor que satisface, ao invés de maximizar, não precisa levar em conta todas as possíveis alternativas comportamentais e, mais do que isso, não precisa se preocupar em saber se as alternativas que está considerando são, de fato, todas as possíveis (Simon, 1976a: xxx). As alternativas podem ser descobertas seqüencialmente, por processos de busca, e a busca interrompida quando uma alternativa satisfatória é encontrada. Isto permite desvincular a dimensão dos custos de busca da dimensão e complexidade da decisão em questão.

Uma outra economia computacional efetivada pelo satisfazimento aparece nos aspectos de valoração da escolha. O decisor que satisface não necessita reduzir todas as dimensões do valor a um denominador comum - utilidade, por exemplo - mas pode fazer uso de múltiplos critérios sem necessidade de calcular o tradeoff entre eles (Simon, 1987: 244).

Uma vez que os padrões de aceitabilidade fazem parte da descrição da situação de escolha - são premissas de valor pertencentes ao ambiente de escolha - a teoria não se cala a respeito de como estes são estabelecidos e modificados. O mecanismo de ajuste destes critérios é o mecanismo psicológico do nível de aspiração: numa seqüência de escolhas, na medida em que se mostra fácil encontrar alternativas que atendam aos critérios, o nível de aspiração é gradualmente elevado e, inversamente, na medida em que é difícil encontrá-las, o 
nível é gradualmente reduzido. Trata-se de um mecanismo de feedback, de tentativa e erro (Simon, 1987: 244; March e Simon, 1958: 141).

\subsubsection{Modelos simplificados da realidade}

Segundo Simon, em função das limitadas capacidades intelectuais humanas, um outro atalho adotado no processo decisório é a utilização pelo decisor de modelos drasticamente simplificados da realidade. Ele se comporta racionalmente relativamente a este modelo, de tal forma a não ter de lidar com a realidade em toda a sua complexidade (Simon, 1947: 81-83; 1976a: xxix; March e Simon, 1958: 150-151). Nas palavras do autor:

... the first consequence of the principle of bounded rationality is that the intended rationality of an actor requires him to construct a simplified model of the real situation in order to deal with it. He behaves rationally with respect to this model, and such behavior is not even approximately optimal with respect to the real world. (Simon, 1957: 199)

Os modelos simplificados tentam capturar os aspectos mais relevantes da realidade, sem no entanto carregar toda a complexidade da situação (March e Simon, 1958: 169). O modelo deve resultar em algo suficientemente simples para que possa ser lidado por processos de solução de problemas (March e Simon, 1958: 151) (e neste sentido trata-se de uma aplicação particular, embora importante, da idéia de satisfazimento). Estes modelos resumem parte significativa do conhecimento que é aplicado numa decisão e, em particular, do conjunto de premissas factuais que relacionam ações a seus resultados.

Um conjunto restrito de variáveis relevantes é selecionado e a interação entre elas entendida em termos de conexões causais (ou sistêmicas) restritas e simplificadas, onde as cadeias causais relevantes são em geral bastante curtas. Apenas os fatores próximos - causal, temporal e espacialmente falando - são levados em consideração. Este conjunto de variáveis é tomado como suficientemente isolado do resto do mundo e assim as conseqüências da ação podem ser pensadas apenas em termos dele. Duas alternativas comportamentais consideradas numa determinada decisão, por conseguinte, diferirão em apenas uns poucos aspectos, sendo em todo o resto idênticas (Simon, 1947: 69).

Segundo Simon, este salto é baseado na crença de que o mundo é, no geral, rarefeito, e de que, de fato, para uma dada decisão apenas alguns poucos aspectos são relevantes. Além disso, o fato de que o comportamento racional é, podemos dizer, freqüentemente bem sucedido dá alguma fundamentação a esta crença. Segundo o próprio: 
He is content with this gross simplification because he believes that the real world is mostly empty - that most of the facts of the real world have no great relevance to any particular situation he is facing and that most significant chains of causes and consequences are short and simple. Hence, he is content to leave out of account those aspects of reality - and that means most aspects - that appear irrelevant at a given time. He makes the choices using a simple picture of the situation that takes into account just a few of the factors that he regards as most relevant and crucial. (Simon, 1976a: xxix$\mathrm{xxx})^{127}$

Mais do que isso, a própria possibilidade do exercício da racionalidade por organismos com capacidades cognitivas limitadas em alguma medida depende de que estes "espaços" relativamente isolados existam. Nas palavras do autor:

Rational choice will be feasible to the extent that the limited set of factors upon which decision is based corresponds, in nature, to a closed system of variables - that is, to the extent that significant indirect effects are absent. (Simon, 1947: 83)

Além disso, vemos também que a adequação da decisão dependerá da adequação do modelo à realidade, e da medida em que efeitos indiretos forem realmente pouco relevantes.

The problem of discovering what factors are, and what are not, important in any given situation is quite as essential to correct choice as a knowledge of the empirical laws governing those factors that are finally selected as relevant. (Simon, 1947: 82-83)

Em função desta simplificação, os seres humanos podem tomar decisões de acordo com simples regras de bolso que tornam o problema de decisão tratável por suas capacidades (Simon, 1976a: xxx). Em termos mais técnicos, eles se utilizam de procedimentos heurísticos na tomada de decisões. Prever o comportamento passa, conseqüentemente, por entender como este modelo simplificado é construído (Simon, 1957: 199). Em outras palavras, entender como é feita a representação da situação, ou como o problema é formulado.

\subsubsection{Hierarquia de decisões}

Um procedimento análogo à adoção dos modelos simplificados que resumem o conteúdo factual empregado numa decisão é a fatoração dos objetivos no processo de

\footnotetext{
${ }^{127}$ Uma pequena parábola é usada para ilustrar o ponto (Simon, 1947: 82): “There is a story to the effect that a statistician once found a very high correlation between the number of old maids and the size of the clover crop in different English countries. After puzzling over this relation for some time, he was able to trace what appeared to him to be the causal chain. Old maids, it appeared, kept cats; and cats ate mice. Field mice, however, were natural enemies of bumblebees, and these, in turn, the chief agents in fertilizing the flower of the clover plants. The implication, of course, is that the British Parliament should never legislate on the subject of marriage bonuses without first evaluating the effect upon the clover crop of reducing the spinster population". O recado, claramente, é de que "efeitos borboleta" não fazem parte dos expedientes de decisão usuais.
} 
valoração. Simon argumenta que a principal maneira de fazê-lo consiste na formação de uma hierarquia de meios e fins. Uma tarefa maior é subdividida em uma seqüência de tarefas menores e mais simples, e estas levam à execução da maior. Cada tarefa menor é um meio para a realização da maior, mas ela mesma possui um fim, que, no entanto, é subobjetivo do objetivo mais amplo. A divisão do objetivo amplo em uma série de subobjetivos, numa cadeia hierárquica de meios e fins, constitui a fatoração.

Segundo March e Simon (1958: 151-152), a fatoração dos objetivos é característica tanto do comportamento individual quanto do organizacional, embora nas organizações ela seja tipicamente mais elaborada e mais evidente. De qualquer maneira, a razão para fatorar os objetivos é a mesma para ambos: a necessidade de tornar a situação a cada momento suficientemente simples para ser tratável por uma mente humana.

Os propósitos e a racionalidade da ação estão ligados através de uma hierarquia de decisões, afinal a racionalidade é definida com relação aos propósitos da ação. Nas palavras de Simon:

The concept of purposiveness involves a notion of a hierarchy of decisions - each step downward in the hierarchy consisting in an implementation of the goals set forth in the step immediately above. Behavior is purposive in so far as it is guided by general goals or objectives; it is rational in so far as it selects alternatives which are conducive to the achievement of the previously selected goals. (Simon, 1947: 5)

O esquema meios-fins tem limitações para avaliar objetivamente a racionalidade de uma escolha (Simon, 1947: 65). ${ }^{128}$ No entanto, este esquema se mostra adequado para se pensar um processo de decisão subjetivamente racional e a fatoração da estrutura de valores envolvida e, mais do que isso, é amplamente empregado na prática. À hierarquia das decisões corresponde uma hierarquia dos fins, pois na medida em que as decisões são hierarquizadas cada nível determinando os objetivos do nível abaixo - cada subobjetivo passa a depender de outros objetivos mais distantes (de níveis hierárquicos superiores), sendo meio com relação a eles. Como explica Simon:

\footnotetext{
${ }^{128}$ As razões listadas são as seguintes (Simon, 1947: 65): Primeiro, o esquema meios-fins tira a ênfase dos aspectos comparativos da escolha, na medida em que normalmente tende a deixar de lado fins alternativos afetados por uma decisão. Segundo, na prática o esquema falha em separar elementos factuais e de valor na decisão, pois a separação completa entre meios e fins é difícil de ser atingida, uma vez que os meios alternativos tipicamente tem implicações de valor para além do objetivo considerado. Em terceiro lugar, a terminologia meios e fins não é boa para tratar do papel do tempo na tomada de decisão, pois é difícil com ela distinguir entre as conseqüências para um intervalo de tempo e as conseqüências para intervalos futuros, dando proeminência às primeiras.
} 
The significance of the 'means-end' relationship now becomes clearer. ... A means-end chain is a series of anticipations that connect a value with the situations realizing it, and these situations, in turn, with the behaviors that produce them. Any element of this chain may be either 'means' or 'end' depending on whether its connection with the value end of the chain, or its connection with the behavior end of the chain, is in question. (Simon, 1947: 74)

É através desta estrutura hierárquica dos fins que o comportamento atinge integração e consistência, pois cada alternativa comportamental se conecta a esta hierarquia e pode ser valorada através dela em termos de valores "últimos" (Simon, 1947: 63). O que não quer dizer que esta integração seja perfeita, ressalta Simon:

It is also as true of organizational as of individual behavior that the means-end hierarchy is seldom an integrated, completely connected chain. Often the connections between organization activities and ultimate objectives is obscure, or these ultimate objectives are incompletely formulated, or there are internal conflicts and contradictions among the ultimate objectives, or among the means selected to attain them. ...

Both organizations and individuals, then, fail to attain a complete integration of their behavior trough consideration of these means-end relationships. Nevertheless, what remains of rationality in their behavior is precisely the incomplete, and sometimes inconsistent, hierarchy that has just been described. (Simon, 1947: 64)

Se idealmente podemos ter clareza na distinção entre elementos de valor e de fato na decisão, na prática a separação não é tão simples. Foi mencionada acima a hierarquia de decisões. No dia-a-dia, os valores utilizados na maior parte das decisões são instrumentais, no sentido de que pertencem a estágios intermediários desta hierarquia. Estes valores são derivados de uma relação meios-fins para os estágios mais elevados, e são valorizados em si mesmos em função de uma antecipação resultante desta relação assumida. Portanto, nestas decisões intermediárias, o processo de valoração tem um conteúdo factual importante relativo à validade empírica das relações meios-fins assumidas relativamente ao níveis superiores da hierarquia (Simon, 1947: 52-53).

Além disso, este processo depende da operacionalidade dos fins ou objetivos envolvidos, pois a pertinência do critério para a ação racional depende dela. Um objetivo é operacional na medida em que se percebam meios de avaliar a relação entre as ações alternativas e a efetividade delas do ponto de vista do objetivo, ou seja, se houver meios para medir em que grau o objetivo está sendo atingido e a relação desta realização com as ações 
tomadas. ${ }^{129}$ Simon (1976a: xxxiv-xxxv) afirma que objetivos muito gerais, uma vez que não são operacionais, não são bons critérios para a decisão - tome-se, por exemplo, os objetivos de "lucro de longo prazo" ou de "bem-estar social". Assim, as decisões tenderão a se dar em torno dos objetivos mais elevados que sejam operacionais, como "participação no mercado", ou "receita", ou "vendas", etc, no caso de uma firma. O modelo simplificado se cristaliza em torno de tais (sub)objetivos.

$\mathrm{Na}$ visão de Simon, este processo de hierarquização das decisões está calcado em propriedades bastante gerais do mundo. ${ }^{130}$ As decisões são hierarquizadas pelo mesmo motivo que as organizações (entre outras coisas) também o são:

What I have been asserting, then, in the preceding paragraphs is that one of the near universal aspects of organizational form, hierarchy, reflects no specific properties of man, but a very general one. An organization will tend to assume hierarchical form whenever the task environment is complex relative to the problem-solving and communicating powers of the organization members and their tools. Hierarchy is the adaptive form for finite intelligence to assume in the face of complexity. (Simon, 1960: 43)

$\mathrm{O}$ argumento das restrições à racionalidade foi desenvolvido por Simon no início de sua carreira como cientista, no contexto da teoria das organizações e nas pesquisas que desenvolveu até meados da década de 1950. Acredito que pode-se dizer com propriedade que este é o argumento ainda nos dias de hoje mais associado ao trabalho de Simon, e possivelmente o mais repetido. Mais tarde ele se deu conta de que a racionalidade restrita pecava por ser um argumento construído "em negativo". Historicamente ele foi elaborado como um contraponto à hiperracionalidade postulada na economia. ${ }^{131}$ Mas, mais importante

\footnotetext{
${ }^{129} \mathrm{Na}$ definição dos autores: "The goals that are included in the definition of the situation influence choice only if there are some means, valid or illusory, for determining the connections between alternative actions and goal satisfaction ... . When a means of testing actions is perceived to relate a particular goal or criterion with possible courses of action, the criterion will be called operational. Otherwise the criterion will be called nonoperational." (March e Simon, 1958: 155, ver também p.42)

${ }^{130}$ A idéia das hierarquias, de que o mundo se organiza hierarquicamente, na obra de Simon é um pano de fundo para quase tudo que li dele. Uma apresentação detalhada dela pode ser encontrada em Simon (1996b), em especial o capítulo (esse de 1962) "The architecture of complexity: Hierarchic systems".

${ }^{131}$ De maneira mais precisa ainda, Simon constrói sua teoria em contraposição à teoria neoclássica no sentido forte de que parte desta última: "Sobre Simon, o relevante a antecipar nesse contexto é que ele, como Ansoff, partiu da iluminação neoclássica. Maximização era o tema de seu livro clássico, Administrative Behavior (1947), da mesma forma em que satisfazimento passou a sê-lo noutro clássico revolucionário, em co-autoria com March, Organizations (1958). ... Simon constatou a inaplicabilidade direta da teoria neoclássica. ... Apresentei diretamente para Simon essas primeiras verificações, numa conversa em junho de 1991. Ele não só confirmou, como indicou-me ainda o artigo em que o conceito de satisfazimento já apareceu bem caracterizado, 'A behavioral model of rational choice' (1955) - a propósito, Simon gostou muito de minha tradução de satisficing para satisfazimento, palavra buscada no português arcaico, em vez de satisfação, como vem sendo divulgado no Brasil; ele também gastou tempo na busca da palavra inglesa apropriada." (Silveira, 1994: 73). Este fato é pouco
} 
que isso, o argumento teórico é construído em torno do que as pessoas não conseguem fazer. O próprio Simon reconhece a necessidade de um passo adicional na conferência que deu por ocasião do prêmio Nobel:

In Administrative Behavior, bounded rationality is largely characterized as a residual category - rationality is bounded when it falls short of omniscience. And the failures of omniscience are largely failures of knowing all the alternatives, uncertainty about relevant exogenous events, and inability to calculate consequences. There was needed a more positive and formal characterization of the mechanisms under conditions of bounded rationality. (Simon, 1979a: 502)

O envolvimento de Simon com a psicologia - na vertente que ajudou a fundar, a ciência cognitiva - o permitiu levar adiante uma construção mais positiva de suas idéias, e daí surgiu o conceito de racionalidade procedimental. Há uma relação profunda entre os dois conceitos sem dúvida, mas a racionalidade procedimental deve ser entendida como um desenvolvimento edificado sobre a racionalidade restrita.

\subsection{Racionalidade procedimental}

Como apontei no relato biográfico de Simon, na segunda metade da década de 1950 seu foco de pesquisa se alterou, passando de uma atenção em como o ambiente organizacional influenciava o comportamento para uma ênfase nas características psicológicas individuais. Passou da teoria das organizações para a ciência cognitiva e a inteligência artificial, da tomada de decisão para a solução de problemas, e nesta passagem ele se afastou da ciência econômica.

A retomada das preocupações de Simon com temáticas econômicas girou em torno do Prêmio Nobel que recebeu. O resgate de suas polêmicas com os economistas iniciou-se a partir do início dos anos $1970 .{ }^{132}$ Os principais temas desenvolvidos por Simon nesta época foram três. O primeiro, e de maior repercussão, foi a distinção entre a racionalidade

alardeado por Simon, ao contrário, me parece que algumas pistas falsas foram lançadas para protegê-lo, isso explica comentários como os de Sent (1999) ao resenhar a quarta edição de Administrative Behavior: "Yet, much like the early reviewers, contemporary economists are likely to find themselves more confused concerning the 'revolutionary' aspects of Simon's 'heresy' after having read the manuscript."

${ }^{132}$ Ele recebeu o prêmio em 1978. 
procedimental e a racionalidade substantiva, numa tentativa de fazer uma incorporação positiva dos aspectos psicológicos da racionalidade restrita.

This distinction between procedural and substantive rationality, which I then began to develop, provided an opportunity to sketch out positively the (psychological) theory of procedural rationality.

In addition to the Navplion [Simon, 1976b] and Ely [Simon, 1978a] papers, I wrote another in the same vein for my Festschrift celebration: 'On How to Decide What to Do' [1978c]. In all of these papers, I tried to show that economics has to be concerned with computation - with the process people actually use to make decisions - and has to describe the nature of these processes. (Simon, 1996a: 324)

O segundo tema foi um ataque frontal à teoria neoclássica e consistiu em questionar o respaldo empírico desta teoria, mostrando que, em geral, os resultados da teoria econômica tradicional dependem mais fortemente de hipóteses auxiliares, cuja validade empírica tipicamente não é discutida, do que das hipóteses centrais da teoria, em particular da hipótese de maximização. $O$ terceiro tema tem um caráter especulativo e trata de avaliar o descompasso entre o papel que as organizações têm na vida econômica e a relevância atribuída a elas, em relação aos mercados, na análise econômica. A tentativa é a de esboçar uma teoria econômica centrada no conceito de organização, ao lado (e talvez acima) do de mercado. No testemunho do autor:

In addition to developing the distinction between procedural and substantive rationality, I have been following through the implications of two other ideas.

One idea, first developed for a symposium in Sweden in the summer of 1983, is that most of the conclusions that neoclassical economists draw do not depend on the assumption of perfect rationality but derive from auxiliary assumptions that are required in order to reach any conclusions at all. Much the same conclusions can be reached from these auxiliary assumptions, with fewer mathematical pyrotechnics, by assuming that the actors are satisficing rather than optimizing. This observation shifts the attention from the unrealistic and superfluous postulates of optimality to the auxiliary assumptions that are doing the real work - and that need empirical testing.

The second idea ... is that we should try to reconstruct economic theory around the concept of organizations rather than the concept of markets, as the former play a much larger role in a modern economy than do the latter. (Simon, 1996a: 325)

No restante desta seção tratarei do primeiro tema, a distinção entre a racionalidade procedimental e a racionalidade substantiva, bem como de suas relações com as pesquisas de Simon na ciência cognitiva e na ciência da computação. O terceiro tema será abordado no próximo capítulo. Porém, por interessante que seja, não discutiremos o segundo tema pois tem 
caráter basicamente crítico, e não acho que, dados os objetivos deste trabalho, discuti-lo nos levaria a caminhos muito diferentes. ${ }^{133}$

\subsubsection{Racionalidade procedimental e racionalidade substantiva}

Simon, em função da interdisciplinaridade de suas pesquisas, foi encontrando ao longo do caminho diferentes tratamentos para os mesmos fenômenos. Em particular, como já foi dito acima, ele se deparou com o que chamou de uma "esquizofrenia aguda" das ciências sociais no seu tratamento da racionalidade (Simon, 1976a: xxvi-xxvii). Ao tentar dar uma definição para o conceito num dicionário de ciências sociais (Simon, 1964), Simon se viu forçado a fornecer duas definições distintas, uma para se adequar ao seu uso na economia e outra ao seu uso na psicologia. Este evento lhe forneceu o mote para a distinção entre a "racionalidade subjetiva", tal como pensada na economia, e a "racionalidade procedimental", tal como pensada na psicologia (Simon, 1982b: 402; 1976b). ${ }^{134}$ O discurso era menos voltado aos psicólogos que aos economistas, e era uma tentativa de mostrar a relevância para a ciência econômica de incorporar os processos de escolha às suas teorias.

A teoria econômica neoclássica, ao modelar o comportamento dos agentes a partir de um conceito de racionalidade substantiva, sugere que o comportamento racional é quase inteiramente determinado pelas características do ambiente, dependendo do agente apenas no que diz respeito às suas preferências ou objetivos. Dessa forma, argumenta Simon (1976b: 130-131), ao assumir a maximização da utilidade e a racionalidade substantiva dos agentes, a economia foi capaz de se isolar completamente da psicologia.

A racionalidade substantiva diz respeito apenas a qual a escolha feita, a seu resultado. No entanto, as pesquisas empíricas de Simon - juntamente com Allen Newell - na área da ciência cognitiva, demonstram veementemente que, em situações complexas, a escolha feita, seu resultado, depende fortemente do processo particular que a gerou, e não apenas dos

\footnotetext{
${ }^{133}$ Mas é de fato interessante, e para os curiosos a respeito recomendo Simon (1986) para começar. A Ely Lecture (Simon, 1978a) e a Nobel Lecture (Simon, 1979a) também discutem o assunto, a primeira de maneira mais direta. Como exemplo dos temas explorados, Simon (1979b) e Simon e Levy (1963) mostram que uma explicação alternativa, e mais simples, para o "fantástico" ajustamento da função Cobb-Douglas às séries históricas seria contábil.

${ }^{134}$ Antes disso ainda, um arauto de From substantive to procedural rationality (1976b) pode ser encontrado num artigo treze anos anterior (Simon, 1963).
} 
objetivos que a orientaram. Assim, torna-se imprescindível saber como a escolha é feita. Como sustenta enfaticamente o próprio autor:

The main import for economic theory of the research in information processing psychology is to provide rather conclusive empirical evidence that the decision-making process in problem situations conforms closely to the models of bounded rationality described earlier. This finding implies, in turn, that choice is not determined uniquely by the objective characteristics of the problem situation, but depends also on the particular heuristic process that is used to reach the decision. It would appear, therefore, that a model of process is an essential component in any positive theory of decision making that purports to describe the real world, and that the neoclassical ambition of avoiding the necessity for such a model is unrealizable. (Simon, 1979a: 507)

O conceito de racionalidade objetiva que foi definido acima é um conceito de racionalidade substantiva. O comportamento é substantivamente racional quando ele é apropriado à realização de objetivos dados, sujeito a condições e restrições dadas (Simon, 1976b: 130). ${ }^{135}$ Já a racionalidade procedimental, de acordo com Simon, teve suas origens na psicologia. O comportamento é procedimentalmente racional quando é resultante de um processo deliberativo apropriado (Simon, 1976b: 131).

Simon (1976b: 132) argumenta que o processo de cálculo racional só se torna interessante quando não é trivial, quando as situações às quais é aplicado fogem do óbvio. Por isso o estudo dos processos cognitivos envolvidos na racionalidade procedimental usualmente são estudados em situações-problema, onde a solução não é transparente para o agente. Há ampla evidência empírica de que o comportamento humano neste tipo de situação se desvia significativamente daquilo que é previsto pelo modelo da teoria econômica tradicional:

A recent review by Rappaport covers experimental tests of SEU (subjective expected utility) maximization, of Bayesian strategies for sequential decisions, and of other models of rational choice under uncertainty. I think the evidence can be fairly summarized by the statements (i) that it is possible to construct gambles sufficiently simple and transparent that most subjects will respond to them in a manner consistent with the SEU theory; but (ii) the smallest departures from this simplicity and transparency produce behavior in many or most subjects that cannot be explained by SEU or Bayesian models. (Simon, 1976b: 134)

Simon, em seu conhecido artigo From substantive to procedural rationality (1976b), argumenta que o fato de que, historicamente, a noção de racionalidade substantiva na

\footnotetext{
${ }^{135}$ Por conseqüência, as definições de racionalidade restrita que foram dadas até o momento também o são, embora eu não tenha me deparado com esta afirmação em nenhuma oportunidade. De qualquer maneira a citação acima esclarece a relação íntima entre a racionalidade restrita e a procedimental: é em função das restrições à
} 
economia ter se desenvolvido de forma isolada e distinta do conceito psicológico (procedimental) de racionalidade podia ser explicado pelo conjunto distinto de questões em torno dos quais cada uma das disciplinas se centrava. No entanto, prossegue o argumento, uma série de novas questões para as quais a ciência econômica estava então se voltando, faria com que a racionalidade procedimental se tornasse essencial também para a economia. ${ }^{136}$ Ele se refere a questões suscitadas, principalmente, por situações onde a incerteza e as expectativas têm um papel importante.

Simon (1976b: 140-141) aponta as teorias de competição imperfeita como um bom exemplo. Ele lembra que, desde que Cournot observou que, quando um mercado é suprido por poucos produtores, a noção de maximização de lucro se mostrou mal definida (uma vez que a escolha ótima para cada um dos participantes do mercado depende da escolha tomada pelos demais) a noção de racionalidade substantiva na teoria econômica está em xeque. Mesmo a teoria dos jogos, criada para tratar de situações deste tipo, tem servido mais para demonstrar a profundidade das dificuldades do que para dissipá-las. Ao gerar uma constrangedora profusão de soluções para os jogos - tanto de conceitos de solução, quanto do número de soluções resultante do uso do conceito do equilíbrio de Nash, por exemplo - ela faz questionar a possibilidade de encontrar um critério substantivo único de racionalidade. Nas palavras do autor:

I have referred to the theory of imperfect competition as a 'scandal' because it has been treated as such in economics, and because it is generally conceded that no defensible formulation of the theory stays within the framework of profit maximization and substantive rationality. Game theory, initially hailed as a possible way out, provided only a rigorous demonstration of how fundamental the difficulties really are. (Simon, 1976b: 141)

Simon (1976b: 141) segue argumentando que, para complicar as coisas, a competição imperfeita é antes a regra do que a exceção nas estruturas de mercado existentes na economia. Nesses casos, onde a escolha substantivamente racional para o agente depende das escolhas de outros agentes, para fazer sua própria escolha cada agente precisa fazer suposições a respeito de que ações os outros tomarão. A dificuldade de definir um critério de racionalidade substantiva nestas situações tem levado os economistas a se preocupar mais e mais com os

racionalidade que o ambiente objetivo de escolha não é suficiente para uma teoria da escolha, e que o processo pelo qual a escolha é feita se torna fundamental.

${ }^{136}$ Outros trabalhos da época tratam desta questão são: Simon (1978a, 1978c e 1979a). 
processos utilizados para se chegar às decisões. Na opinião do autor este caminho é estritamente necessário:

There remains, however, a lingering reluctance to acknowledge the impossibility of discovering at last 'The Rule' of substantively rational behavior for the oligopolist. Only when the hope of that discovery has been finally extinguished will it be admitted that understanding imperfect competition means understanding procedural rationality. (Simon, 1976b: 141) $)^{137}$

Além disso, como também demonstram as aplicações de teoria dos jogos, a competição imperfeita é uma entre várias situações onde as escolhas dos agentes são interdependentes. $\mathrm{O}$ problema do oligopolista é apenas um (embora importante) entre tantos casos relevantes para a economia onde os agentes têm de formar expectativas para tomar decisões sob incerteza. Quanto maior a preocupação com a dinâmica da economia, em particular para situações fora do equilíbrio, tanto maior a necessidade da teoria de atribuir importância à influência da incerteza sobre o comportamento. É o que defende Simon, em relação à incorporação das questões dinâmicas na economia:

As economics has moved from statics to dynamics - to business cycle theory, growth theory, dynamic investment theory, theory of innovation and technological change - it has become more and more explicit in its treatment of uncertainty. (Simon, 1976b: 142)

Do ponto de vista de Simon (1976b: 142), a questão relevante é saber como as pessoas se comportam racionalmente num mundo onde são, na maioria das vezes, incapazes de prever com acuidade as características relevantes do futuro. Nestas situações elas podem apenas adotar um procedimento racional de escolha, seja ele de previsão ou de adaptação para o futuro. Mas os procedimentos de previsão não são os únicos processos racionais empregados pelos agentes para lidar com a incerteza, uma série de outras ações para reduzi-la ou para tornar o resultado menos sensível a ela podem ser adotadas (Simon, 1976b: 143-144), tais como: ações para melhorar as previsões, através da obtenção de mais e melhores informações ou do refinamento dos modelos utilizados; ações para amortecer erros de previsão, como estoques ou seguros; ações para reduzir a sensibilidade do resultado às ações dos competidores, como diferenciação de produto ou de mercado; ou ainda a ampliação das alternativas disponíveis quando o risco percebido é elevado, como a diversificação da carteira

\footnotetext{
${ }^{137}$ Knudsen (1993) segue exatamente este mote para discutir a computabilidade ou não de certos problemas econômicos. No meu entender, no entanto, esta afirmação de Simon deve ser interpretada do ponto de vista descritivo, e não do lógico como ele o faz. A mesma questão aparecerá no próximo item onde a computabilidade (lógica) dos problemas será contraposta à computabilidade num tempo razoável.
} 
de investimentos. Se Simon tem consciência das dificuldades envolvidas em levar todos estes fatores em consideração, ele também é consciente da necessidade de fazê-lo:

Confronting a list of contingencies of this sort fills many economists with malaise. How can a unique answer be found to the problem of choice if all of these considerations enter it? How much more attractive is the classical economics, in allowing strong conclusions to be drawn from a few a priori assumptions, with little need for empirical observation. Alas, we must take the world as it is. (Simon, 1976b: 144)

Embora o interesse dos economistas pela incerteza, pela dinâmica da economia e, de maneira mais geral, por situações fora do equilíbrio - e neste ponto estes aspectos se misturam pois o que fazem é acrescentar complexidade à situação de escolha - sejam os principais motivos que Simon (1976b, veja também 1978c: 14) aponta para a necessidade da utilização do conceito de racionalidade procedimental para o avanço da teoria econômica, ele indica outras frentes de pesquisa que têm contribuído para uma maior atenção dos economistas aos aspectos processuais da racionalidade. $\mathrm{O}$ maior contato de economistas acadêmicos com o ambiente dos negócios e das políticas públicas os tem exposto aos processos de decisão empregados na prática. Além disso, a aplicação de técnicas oriundas da pesquisa operacional também tem aproximado os economistas do conceito de racionalidade procedimental. Simon afirma, ainda, que outras disciplinas que surgiram e/ou se desenvolveram em torno do computador digital, além da pesquisa operacional, são relevantes para se pensar os aspectos processuais da racionalidade e tenta buscar lições destas disciplinas para a economia, ponto este que será explorado no próximo item.

\subsubsection{Questões computacionais}

Os campos de pesquisa operacional e ciência administrativa (management science), inteligência artificial, complexidade computacional e ciência cognitiva, todos eles desenvolveram abordagens à racionalidade procedimental (Simon, 1978c: 494). Simon (1978c: 504) argumenta que a ciência econômica poderia se aproveitar dos desenvolvimentos nestes campos para tratar os aspectos processuais da racionalidade em seu domínio. ${ }^{138}$

Simon descreve o campo de pesquisa operacional como consistindo em um corpo teórico normativo, que visa desenvolver técnicas de auxílio à decisão. A pesquisa operacional

\footnotetext{
${ }^{138}$ Mirowski encontraria nexos e alguma ironia histórica nessa recomendação. De qualquer forma, o próprio Simon, mais uma vez, serve como exemplo dos vínculos persistentes entre a pesquisa operacional e a economia.
} 
é, portanto, uma teoria de racionalidade procedimental, pois procura desenvolver métodos ou procedimentos para a tomada de decisão e meios para avaliar os diferentes métodos. Como já afirmei acima, o conjunto de técnicas que fazem parte deste campo são, em parte, familiares aos economistas. Ele lista as seguintes: programação linear, programação dinâmica, programação de inteiros (integer programming), programação geométrica, teoria das filas, análise combinatória, simulação e teoria da busca. Como diz Simon:

What is the goal of basic theory in operations research (OR) and management science? It is to specify good (or best) methods for finding good (or best) decisions in complex managerial situations. OR theory is a theory of computation, of procedural rationality. (Simon, 1978c: 494-495)

Na prática, segue o autor, o desenvolvimento de algoritmos na pesquisa operacional segue um de dois caminhos alternativos: ou reduzir o custo computacional envolvido em domínios de problemas que podem ter o ótimo computado em um tempo razoável, ou desenvolver algoritmos que retornem soluções aceitáveis em um tempo razoável para domínios de problemas onde o ótimo não é computável neste prazo. Este tempo razoável é um tempo prático, e não simplesmente um tempo "finito", como enfatiza Simon:

It gradually dawned on computer scientists, however, that the decidability question was not usually the right question to ask about an algorithm or a problem domain. (So great was the fascination of automata theory and the prestige of the Gödel theorem that the dawning took several decades.) It really did not matter very much whether the answer to a problem would never be forthcoming, or whether it would be produced only after a hundred years. The important questions for computing were the probabilities that answers would be produced in a reasonable computation time (an hour or a day, depending on the importance of the problem), and what the average computing time would be for those problems from a domain that could be solved at all with reasonable amounts of computation. (Simon, 1978c: 501)

Simon usa a programação linear como um exemplo de tipo de problema que tem o ótimo computável. Segundo ele, um bom algoritmo de programação linear é aquele que encontra o ótimo com um custo computacional relativamente baixo (Simon, 1978c: 495). A pesquisa em programação linear é voltada à redução deste custo. No entanto, ao escrever tais algoritmos, normalmente o custo computacional de encontrar o ótimo não é explicitamente comparado - embora exista um tradeoff implícito - com o de computar uma aproximação ao ótimo, isto justamente porque a solução é viável num prazo adequado. A comparação entre os algoritmos é feita, em sua maior parte, ainda por via empírica: conjuntos padrão de problemas são testados para os algoritmos e a eficiência destes é determinada relativamente à de outros 
algoritmos. Existem poucas generalizações neste sentido. ${ }^{139} \mathrm{O}$ autor prossegue afirmando que, quando a dimensão do problema começa a exceder um tamanho limite - tornando-se não apenas caro resolvê-lo, mas impraticável - a preocupação passa a ser a de expandir a fronteira da dimensão dos problemas tratáveis. No entanto, em outros domínios que não o da programação linear, como a programação de inteiros ou a análise combinatória, existe uma série de problemas de importância prática que, mesmo com os recursos computacionais atuais ou previstos para o futuro e os mais eficientes algoritmos disponíveis, estão muito distantes de ter o seu ótimo computável num prazo razoável. Nestes casos é necessária a utilização de procedimentos heurísticos que possibilitem obter uma solução aproximada com um custo computacional razoável, tornando assim explícito o tradeoff entre o custo computacional e a qualidade da solução (Simon, 1978c: 496). Nas palavras do autor:

In summary, OR [operations research] theory is a part of the normative theory of procedural rationality specifying both algorithms for finding optimal or good decisions and procedures, usually empirical and pragmatic, for evaluating such algorithms. Conceptually, these theories are concerned with the tradeoff between the quality of the solution and the cost of finding it, but in most cases, the tradeoff is only implicit. (Simon, 1978c: 496)

A pesquisa operacional, como outras teorias de racionalidade procedimental, leva em conta a eficiência computacional, ou seja, o tempo ou esforço computacional envolvido na solução de um dado problema por um dado sistema computacional. Este sistema, por sua vez, tem suas limitações: tipicamente sua operação é, grosso modo, serial, e ele leva intervalos irredutíveis de tempo para executar operações primitivas. Sendo assim, para qualquer dimensão do problema em vista, a teoria normativa se preocupa sempre em indicar procedimentos que possam efetivamente levar a uma solução com um esforço computacional aceitável, pois não há sentido em prescrever o ótimo do problema quando não existe um algoritmo capaz de encontrá-lo, com um dado sistema, num tempo razoável (Simon, 1976b: 132-133).

Simon afirma que, na prática, na utilização das técnicas oferecidas por estas teorias de racionalidade procedimental para resolver problemas de alguma complexidade, as demandas por computabilidade forçam a simplificação do problema de duas maneiras alternativas: simplificando o modelo para tornar o ótimo praticável ou se contentando com soluções

\footnotetext{
${ }^{139}$ Simon (1978c) comenta algumas delas, oriundas da teoria da complexidade computacional.
} 
satisfatórias ao invés de ótimas. Podemos, por exemplo, dado um problema, representá-lo de maneira linear (como aproximação) e resolvê-lo por programação linear, ou tomar o problema não linear e de resolução mais complicada e satisfacer na solução (também aproximada). Simon considera ambos os comportamentos como de satisfazimento:

Thus, the demands of computability led to two kinds of deviation from classical optimization: simplification of the model to make computation of an 'optimum' feasible, or, alternatively, searching for satisfactory, rather than optimal choices. I am inclined to regard both of these as instances of satisficing behavior rather than optimization. To be sure, we can formally view these as optimizing procedures by introducing, for example, a cost of computation and a marginal return from computation, and using these quantities to compute the optimal stopping-point for the computation. But the important difference between the new procedures and the classical ones remain. The problem has been shifted from one of characterizing the substantively optimal solution to one of devising practicable computation procedures for making reasonable choices. (Simon, 1976b: 140)

O campo da inteligência artificial, por sua vez, é voltado a programar computadores de tal forma que eles sejam capazes de fazer coisas humanóides - a dotá-los de propriedades humanas, em particular as do intelecto - mas não necessariamente, embora freqüentemente, da mesma maneira que os humanos as fazem (Simon, 1978c: 496-497). Sua tarefa prática é a de desenvolver algoritmos que emulem o comportamento humano em situações-problema. Portanto, embora o mote seja outro, a inteligência artificial e a pesquisa operacional se aproximam, como testemunha Simon:

Artificial intelligence is a normative discipline. Like OR [operations research], its goal is to find powerful problem-solving algorithms, and no holds are barred. In fact, there is no real boundary between these two disciplines, and today the theory of heuristic search is being pursued vigorously by both. (Simon, 1978c: 497)

Já a ciência cognitiva, se por um lado tem uma afinidade histórica e prática com a disciplina da inteligência artificial, por outro tem objetivos distintos da mesma e da pesquisa operacional. O fato do próprio Simon ser considerado um pioneiro nas disciplinas da ciência cognitiva e da inteligência artificial revela a afinidade histórica entre os campos. A afinidade prática entre elas surgiu na medida em que se foi percebendo que muitas vezes, mas nem sempre, o melhor jeito para se programar um computador a resolver problemas complexos é, justamente, imitar da forma mais detalhada possível a maneira que as pessoas lidam com a tarefa (Simon, 1978c: 497). 


\subsubsection{Ciência cognitiva}

A ciência cognitiva é um ramo da psicologia, e é uma disciplina descritiva: positiva e não normativa. Ela visa descobrir como seres humanos executam tarefas cognitivas complexas (Simon, 1978c: 497). Segundo o autor, ela se propõe a programar computadores para fazer coisas engenhosas que as pessoas fazem da maneira que elas o fazem, ou seja, utilizando-se dos mesmos processos de informação que elas utilizam.

Como apontei anteriormente, na segunda metade da década de 1950 Simon voltou seu foco de pesquisa para a ciência cognitiva e a inteligência artificial, ${ }^{140}$ para a solução de problemas. A principal diferença entre a tomada de decisão e a solução de problemas são os processos de busca. Uma situação será de solução de problemas na medida em que processos de busca, em particular busca por alternativas, estejam envolvidos. March e Simon, ao discutir esta distinção, trabalham entre os extremos de respostas rotinizadas e de solução de problemas:

At one extreme, a stimulus evokes a response - sometimes very elaborate - that has been developed and learned at some previous time as an appropriate response for an stimulus of this class. This is the 'routinized' end of the continuum, where a stimulus calls forth a performance program almost instantaneously.

At the other extreme, a stimulus evokes a larger or smaller amount of problem solving activity directed toward finding performance activities with which to complete the response. Such activity is distinguished by the fact that it can be dispensed with once the performance program has been learned. Problem-solving activities can generally be identified by the extent to which they involve search: search aimed at discovering alternatives of action or consequences of action. (March e Simon, 1958: 139-140)

O trabalho de Simon em ciência cognitiva foi fundamental para o desenvolvimento de sua teoria comportamental baseada no conceito de racionalidade restrita e também da racionalidade procedimental. Foi ele que possibilitou uma descrição positiva dos mecanismos empregados pelas pessoas ao resolver problemas ou tomar decisões. Os dois conceitos centrais nesta tarefa foram o de satisfazimento e o de busca (Simon, 1979a: 502-503).

Simon argumenta que uma teoria de racionalidade restrita necessita teorizar o processo de busca pois, se as alternativas não são dadas de antemão ao agente, ele tem de procurá-

\footnotetext{
${ }^{140}$ Embora Simon tenha sido uma figura importante nos desenvolvimentos, iniciais e posteriores, da disciplina da inteligência artificial e ele mesmo assumir este papel explicitamente, acredito ser apropriado dizer que o principal foco era de fato a ciência cognitiva pois, em todo o seu trabalho nessas áreas, ele sempre se preocupou em simular os processos cognitivos humanos. Seu trabalho em inteligência artificial se situava na intersecção entre as disciplinas.
} 
las. ${ }^{141}$ É neste ponto que a solução humana de problemas encontra sua especificidade. Os mecanismos de busca utilizados por seres humanos são altamente seletivos: em situações problema complexas as pessoas não fazem buscas sistemáticas e extensivas, elas se utilizam de procedimentos heurísticos para realizá-las. Um grande mestre de xadrez, por exemplo, raramente examina mais de 100 possibilidades, num imenso espaço de alternativas, antes de fazer um movimento (Simon, 1976b: 136). O conceito de busca está intimamente relacionado com o de satisfazimento. Um mecanismo de busca precisa de um critério de parada, Simon postula o satisfazimento para tanto, e aponta evidências empíricas a favor da hipótese de que este é o critério utilizado pelas pessoas em uma vasta gama de situações, em particular as mais complexas. Como resume o autor:

Chess is not an isolated example. There is now a large body of data describing human behavior in other problem situations of comparable complexity. All of the data point in the same direction, and provide essentially the same descriptions of the procedures men use to deal with situations where they are not able to compute an optimum. In all these situations, they use selective heuristics and means-end analysis to explore a small number of promising alternatives. They draw heavily upon past experience to detect the important features of the situation before them, features which are associated in memory with possibly relevant actions. They depend upon aspiration-like mechanisms to terminate search when a satisfactory alternative has been found. (Simon, 1976b: 136)

Outro fruto do trabalho de Simon na ciência cognitiva foi a descrição do "equipamento de processamento de informação humano". A ciência cognitiva também é conhecida como psicologia de processamento de informação (information processing psychology). A idéia por trás dela é pensar o homem como um processador de informações, e descrevê-lo como tal. A racionalidade é aqui equalizada com a computabilidade. Como vimos acima, na pesquisa operacional, o esforço computacional para a resolução de um determinado problema era função do algoritmo empregado e também do sistema no qual este algoritmo roda. Do ponto de vista da ciência cognitiva, portanto, é uma tarefa importante descrever as características deste sistema. O trecho abaixo deixa claro que a analogia com o computador é marcante nesta disciplina: ${ }^{142}$

Like a modern digital computer's, man's equipment for thinking is basically serial in organization. That is to say, one step in thought follows another, and solving a problem

\footnotetext{
141 "Problem solving is often described as a search through a vast maze of possibilities, a maze that describes the environment. Successful problem solving involves searching the maze selectively and reducing it to manageable proportions." (Simon, 1996b: 54)

${ }_{142}$ A idéia aqui é pensar o homem como computador, e não o contrário. No caso da inteligência artificial já é diferente.
} 
requires the execution of a large number of steps in sequence. ... [T] to think that the basic repertoire of processes in the two systems is quite similar. Man and computer can both recognize symbols (patterns), store symbols, copy symbols, compare symbols for identity, and output symbols. These processes seem to be the fundamental components of thinking as they are of computation. (Simon, 1976b: 135)

Simon argumenta que uma característica saliente do pensamento humano é que ele é, no nível simbólico, basicamente serial, ou seja, no geral faz uma, ou umas poucas coisas de cada vez. Uma resolução de um problema complexo será, portanto, composta de uma série, maior ou menor, de passos simples. Ele é insistente neste ponto ao discutir a atividade de solução de problemas:

The evidence is overwhelming that the system is basically serial in its operation: that it can process only a few symbols at a time and that the symbols being processed must be held in special, limited memory structures whose content can be changed rapidly. (Simon, 1996b: 81$)^{143}$

Simon (1996b: 59-74) também analisa as propriedades da memória humana. Ele argumenta que ela pode ser dividida em memória de curto prazo e memória de longo prazo. A memória de longo prazo é basicamente ilimitada, ou pelo menos não se conhece seu limite, no entanto, armazenar um "bloco" "144 na memória de longo prazo leva em torno de oito segundos. A memória de curto prazo tem armazenamento comparativamente rápido, de décimos de segundo a um par de segundos, no entanto tem uma capacidade extremamente limitada, de apenas algo em torno de sete blocos. ${ }^{145} \mathrm{O}$ processamento da informação se dá (serialmente) sobre a memória de curto prazo. Segundo Simon, a organização da memória é associativa, formalmente: ela tem a forma de estruturas de listas:

...[W]e are led to the hypothesis that memory is an organization of list structures (lists whose components can also be lists), which include descriptive components (two-termed relations) and short (three-element or four-element) component lists. (Simon, 1996b: 74)

\footnotetext{
${ }^{143}$ O debate "paralelo vs serial" aparentemente é particularmente controvertido no interior das disciplinas da inteligência artificial e da ciência cognitiva, Simon expressa sua posição da seguinte maneira: "Another new development in cognitive science that I have watched with interest, but from a distance, is the vigorous activity in constructing simulations of intelligence that employ 'neural networks' or other highly parallel architectures, instead of the serial symbolic systems that we have used in our work. My view, which I won't defend here, has been that these 'connectionist' architectures have a role to play (for instance, in simulating visual and auditory sensory processes), but that they will not replace physical symbol systems as models of higher mental processes." (Simon, 1996a: 328)

${ }^{144}$ Um bloco é basicamente a maior unidade de informação reconhecida, formalmente: "A chunk is a maximal familiar substructure of the stimulus." (Simon, 1996b). Por exemplo, a palavra "bola" comporia um bloco para qualquer pessoa que fale português, no entanto "wtrz" comporia quatro blocos na memória (para qualquer pessoa que conheça o alfabeto). Da mesma maneira a disposição completa de um tabuleiro de xadrez de um jogo conhecido pode ser armazenada em um ou poucos blocos por um grande mestre e exige muito mais de um leigo. ${ }^{145}$ Os números aqui não devem ser levados à risca, registre-se apenas sua ordem de grandeza.
} 
Como discutimos acima, esta limitada capacidade computacional humana é compensada, ou melhor dizendo, lidada, pela busca altamente seletiva e pelo conhecimento acumulado na memória. ${ }^{146}$ No entanto, segue o autor, em situações complexas, que são a maioria das interessantes, nossas capacidades ainda nos deixam longe da possibilidade de agir de forma substantivamente racional.

For most problems that man encounters in the real world, no procedure that he can carry out with his information processing equipment will enable him to discover the optimal solution, even when the notion of 'optimum' well defined. There is no logical reason why this need be so; it is simply a rather obvious empirical fact about the world we live in - a fact about the relation between the enormous complexity of that world and the modest information-processing capabilities with which Man is endowed. (Simon, 1976b: 135)

Mas, mais importante que a analogia constitutiva entre computador e mente, é o papel das linguagens de programação na teoria. Na pesquisa em ciência cognitiva de Newell e Simon suas teorias eram formalmente escritas como programas de computador. O método de proceder era construir programas que emulassem passo a passo os processos de tomada de decisão humana, tal como descritos em protocolos de pensamento-alto (thinking-aloud protocols) obtidos em laboratório a partir da resolução de problemas padrão. Os programas construídos simulariam então os processos de processamento de informação humanos, a comparação era feita então entre as execuções do programa e os protocolos gravados. Programas como explicação e simulação como método empírico, eis a base da pesquisa destes cientistas em ciência cognitiva. É difícil exagerar a importância deste procedimento de pesquisa neste contexto.

Uma outra idéia importante de Simon neste contexto é a de que os processos cognitivos humanos são bastante simples e a complexidade observada em seu comportamento é na verdade um reflexo da complexidade do ambiente ao qual responde (Simon, 1996b: 51-53). O autor dá como exemplo o caminho tortuoso de uma formiga andando na areia da praia, que pode ser explicado pelas sinuosidades da areia e por propriedades simples da formiga, como ela ter uma vaga idéia de onde se encontra o formigueiro e, no entanto, não poder prever todos os obstáculos do caminho. Mas, como já discutimos, o comportamento humano é propositado. Assim, como o comportamento se adapta a objetivos, ele revela apenas os limites da adaptabilidade do organismo ao ambiente (Simon, 1996b: 81). Daí ele infere que a

\footnotetext{
146 "The expert chessplayer's heuristics for selective search and his encyclopedic knowledge of significant patterns are at the core of his rationality in selecting a chess move." (Simon, 1976b: 136)
} 
complexidade aparente do comportamento humano é fruto das suas limitações frente a um ambiente complexo.

\subsection{Racionalidade}

Neste capítulo discutimos o uso teórico feito por Simon do conceito de racionalidade e vimos como sua teoria comportamental se estrutura sobre tal conceito, no sentido de que quase tudo que é invariante ou mais geral do comportamento em sua teoria tem seu fundamento aí. Antes de passar ao próximo capítulo é importante reter algumas coisas.

Primeiro, o comportamento é teorizado por Simon como racional sob a justificativa de que, em geral, ele tem a intenção de racionalidade. E, a despeito dele ressaltar as restrições à racionalidade no comportamento, sua teoria corresponde a um aumento de escopo do conceito de racionalidade no sentido de que uma classe maior de comportamentos pode ser tratada como racional.

Segundo, no centro da teoria comportamental de Simon estão a tomada de decisão e a solução de problemas. Como vimos, o caminho que leva à ação racional é: propósitos ou motivações $\rightarrow$ escolha / decisão $\rightarrow$ ação. O nexo imediato entre a tomada de decisão e comportamento é pouco discutido e parece ser justificado pela hipótese de que não seria racional decidir fazer algo que não se pode cumprir. De qualquer maneira, "o fio da meada é o estudo do decisor".

Em terceiro lugar, o argumento das restrições à racionalidade implica na necessidade de uma caracterização mais detalhada e localizada do agente: de suas características psicológicas (cognitivas) e do contexto no qual ele se comporta. Sob a alcunha de características psicológicas encontramos uma série diversificada de coisas. Encontramos, é certo, uma descrição quase física do "equipamento de processamento de informações humano", construído em analogia direta com o computador. Além disso, há o que pode ser apropriadamente agrupado sob o termo procedimentos de decisão. Aí encontramos os mecanismos simplificadores da decisão: satisfazimento e os processos de busca e o mecanismo de níveis de aspiração a ele associados, modelos simplificados da realidade tentam dar conta da representação subjetiva da situação, e a hierarquia de decisões associada a uma cadeia de meios e fins permite a integração, ainda que imperfeita, de decisões localizadas 
em nexos que as transcendem. Além destas grandes classes de procedimentos Simon advoga a criação de um inventário de procedimentos empregados na prática pelos agentes através de pesquisa empírica detalhada.

Finalmente, encontramos também neste capítulo a passagem de Simon do conceito de racionalidade restrita, e de sua construção em negativo, para o conceito de racionalidade procedimental: da preocupação com qual é a decisão tomada, qual o resultado dela, para a preocupação com como ela é tomada, com o processo que a gerou. Como vimos, nas teorias normativas de tomada de decisão - pesquisa operacional, por exemplo - a busca é por bons procedimentos de decisão, e há sempre um tradeoff, implícito ou explícito, entre o custo computacional e a qualidade da solução. 


\section{Organizações}

Se praticamente todo o pensamento de Simon ao longo de sua carreira científica orbitou em torno da idéia de racionalidade, não é menos verdade que os seus esforços mais sistemáticos e importantes em direção à ciência econômica giraram também em torno do conceito de organização. Como apontei acima, Simon recebeu o prêmio Nobel por sua pesquisa sobre o processo de tomada de decisão no interior de organizações econômicas. Isto não se deu por acaso. A idéia de racionalidade restrita - embora tenha brotado apenas após o contato de Simon com os computadores - foi semeada a partir de suas reflexões sobre organizações, e as organizações sempre forneceram o principal ambiente no qual os agentes restritamente racionais se movimentam. Mesmo o conceito de racionalidade procedimental nos leva diretamente à organização, na medida em que conhecer os procedimentos de decisão efetivamente empregados pelos agentes implica em conhecer as organizações, pois é dentro delas que, na prática, a maior parte das decisões econômicas se dá.

Um dos três temas econômicos explorados por Simon após ter recebido o Nobel foi justamente avaliar as implicações de reconstruir a teoria econômica em torno do conceito de organizações ao invés do de mercados (Simon, 1996a: 325). O mote para este tema é dado pela percepção da proeminência do papel das organizações com relação ao dos mercados numa economia nos dias de hoje. $\mathrm{O}$ argumento perseguido pelo autor visa, por um lado, pensar porque esta proeminência ocorre na prática: Por que a maior parte das interações entre as pessoas se dá, de fato, no interior de organizações? E, por outro lado, discutir as conseqüências desta observação para a teoria econômica. Implícita neste argumento está a visão de Simon do que vem a ser organização, na qual a tomada de decisão é estrutura analítica privilegiada. Para resgatar esta visão buscarei, em trabalhos mais antigos de Simon sobre teoria das organizações, o papel da organização na tomada de decisões, a influência que ela exerce sobre o comportamento. Uma tentativa de delinear as feições da teoria econômica pensada nestes termos passa necessariamente por este resgate pois, como foi argumentado acima, uma vez admitidas as restrições à racionalidade, o ambiente de escolha assume um papel central no comportamento. Mas as organizações constituem a maior parte, e para a economia talvez a parte mais importante, deste ambiente. Da teoria comportamental de 
Simon, portanto, a racionalidade é a estrutura e a organização é o contexto no qual esta estrutura se aplica. E ambas as partes são essenciais:

A theory of administration or of organization cannot exist without a theory of rational choice. ... It can be said with equal truth that a theory of rational choice can hardly exist without a theory of organization. ... The characteristic environment of man is constituted not of nature but of his fellows. (Simon, 1957: 196)

\subsection{Organizações e mercados}

Simon aponta a enorme importância que as organizações têm nas vidas das pessoas que vivem numa sociedade hodierna: é no interior de organizações formais que a grande maioria das interações entre as pessoas se dá neste tipo de sociedade, é dentro delas que a maior parte das pessoas passa a maior parte do tempo. Em particular, no que concerne à economia, grande parte da interação acontece no interior de firmas:

... the lives of most people in a modern industrial society are not spent mainly in markets, but in the interiors of individual firms. Eighty per cent or more of the working population is employed by firms, and only a small fraction of these have direct contact with the firm's markets to any significant extent. Their working lives are spent largely well inside the skin of the firm. (Simon, 1997a: 35)

Alocar recursos para os usos em que eles têm maior valor é uma importante propriedade dos mercados. Além disso, sob condições de competição perfeita, eles são capazes de engendrar uma alocação que é Pareto ótima. Diante disso, Simon (1997a: 46) ressalta que é necessário identificar condições diferentes das de otimalidade para explicar a existência de organizações no mundo real, pois sob essas o mundo seria composto de contratantes independentes interagindo apenas através dos mercados.

Desta perspectiva, Simon (1991: 25-26) identifica duas situações que são interessantes para pensar sobre esta questão. A primeira delas se refere à relação empregatícia: por que indivíduos e firmas escolhem esta forma contratual, que é uma forma incompleta no sentido de que não tem todos os seus termos especificados, para efetuar as trocas referentes à força de trabalho? Mais do que isso, porque os empregados geralmente trabalham além do necessário onde "necessário" aqui é pensado como aquilo que pode ser imposto dos termos do contrato de trabalho - em prol dos objetivos da firma. A segunda situação diz respeito às decisões de 
produzir-ou-comprar (make-or-buy decisions) ${ }^{147}$ das firmas, que determinam as fronteiras entre estas e os mercados. Tendo estas situações em mente, ele analisa a eficiência relativa entre organizações e mercados ao considerar as vantagens e desvantagens da centralização ou descentralização de atividades econômicas.

\subsubsection{Identificação e autoridade: meios de coordenação}

Em termos numéricos, sem dúvida alguma, a maior parte dos agentes da economia são empregados. Estas pessoas entram no mercado de trabalho e vendem a sua força de trabalho em troca de uma remuneração. Ao fazê-lo, vendem o seu tempo e esforço (quase) indiferenciado à firma, passando a estar submetidas a uma relação de autoridade da organização para com elas: permitindo que seu comportamento seja determinado, enquanto no trabalho, pela organização. Por que esta é a forma escolhida para a troca de força de trabalho? A resposta da boa teoria econômica é, naturalmente, que assim é efetuada porque é percebida como a forma mais vantajosa por ambas as partes. Segundo Simon (1997a: 34; 1947: 116; March e Simon, 1958: 90-91), os empregados podem ser indiferentes entre uma gama de diferentes solicitações, e o próprio contrato de trabalho especifica as linhas gerais do trabalho a ser realizado. Assim, no interior de uma zona de aceitação eles permitem que seu comportamento seja determinado pela autoridade legítima da organização. Os empregadores, continua o autor, podem solicitar de seus empregados determinadas ações no momento em que estas se tornem necessárias. No momento em que o contrato é assinado, as especificidades do que será necessário que o empregado faça ao longo de todo o período em que vier a estar empregado são, obviamente, incertas. E isso tudo pode ser feito sem que, na medida em que novas necessidades surjam, novas negociações sejam necessárias a todo instante. $^{148}$

Simon (1991, 1997a) nota que a Nova Economia Institucional (New Institutional Economics) - que fornece a visão predominante da firma na teoria econômica contemporânea

\footnotetext{
147 "Make-or-buy decisions" me parece ser razoavelmente bem traduzido por "decisões de terceirização (ou não terceirização)". Por outro lado, Simon não usou termos como "outsourcing”, “subcontracting”, ou "contracting $o u t$ ", que seriam equivalentes mais diretos do termo "terceirização" em português. Por este motivo fiz uma tradução mais literal.

${ }^{148}$ A relação empregatícia será tratada com mais detalhe adiante.
} 
- vê a imposição dos termos do contrato de forma muito mais problemática do que a descrição da relação empregatícia acima sugere. Assumir que administradores e empregados são egoístas, que buscam apenas seu auto-interesse, implica que eles só agirão em prol da maximização dos lucros da firma se esta ação puder ser imposta pelos acionistas, caso contrário o oportunismo dos agentes se torna um problema. Assim, uma preocupação central desta linha teórica passa ser como desenhar contratos que possam ser impostos e que façam coincidir, em alguma medida, o interesse do empregado com o do acionista. Como reforça Simon, de acordo com os pressupostos desta teoria, o empregado não persegue os objetivos da empresa se houver qualquer conflito com seu próprio auto-interesse:

It was not that, in these descriptions of employment, the employees advanced the firm goals in conflict with their own interests, but that the employment contracts were shaped in such a clever, perhaps even Machiavellian, fashion, that the interest of the firm and self-interest were made to coincide - to a degree. (Simon, 1997a: 34)

As explicações da Nova Economia Institucional giram em torno dos conceitos de "custos de transação", "oportunismo" (moral hazard), "assimetria de informação" e "informação incompleta". Os problemas com que ela se debate são do tipo "agente-principal”, "seleção adversa" ou de "sinalização" (Simon, 1991: 26). Mas Simon parte de outros pressupostos:

Suppose, for example, that managers and employees were altruistically inclined toward the firm: that they obtained utility from seeing it prosper. Then the intricate contracts of the New Institutional Economics would be superfluous. The mere act of employment would guarantee loyalty to the firm's goals without the need for detailed supervision of behavior, or concern for slacking and cheating. But isn't this pure utopian moonshine? Does it call for even a moment's consideration? (Simon, 1997a: 39)

Acompanhemos o argumento por partes. Já foi dito que o empregado, ao ingressar na organização, se coloca sob uma relação de autoridade com relação à organização. No entanto, ressalta Simon (1991: 32-33), mais do que a simples obediência a comandos é necessário para que o comportamento dos empregados seja conducente ao objetivo da firma. Também é necessário muito mais do que o cumprimento estrito dos termos do contrato de trabalho, como bem atestam as "operações-padrão" da Polícia Federal nos aeroportos. Para o bom funcionamento da firma é fundamental a iniciativa dos empregados em perseguir os objetivos dela, em especial no que se refere aos empregados de nível administrativo. De acordo com Simon, a necessidade de projetar (design) produtos, estratégias, estrutura organizacional etc faz com que a iniciativa dos empregados, neste sentido, seja imprescindível: 
The design of products (and not just the choice of products) is often a central concern, and marketing procedures, manufacturing procedures, pricing policies, the central organization structure, even long-term strategies are designed, and not just chosen. Design calls for initiative, focus of attention on major problems, search for alternatives. One cannot chose best, one cannot even satisfice, until one has alternatives to choose from. (Simon, 1997a: 36)

O bom funcionamento, e na medida em que isto é uma questão relativa, a própria existência das firmas que operam numa economia dependem desta questão. Pois, uma vez que as firmas funcionam relativamente bem - que elas existem e se mantêm - e que para isto dependem da iniciativa dos seus empregados, resta esclarecer porque os empregados agem assim. O que os leva a trabalhar, em geral, em favor dos objetivos da firma?, pergunta Simon:

In most organizations, employees contribute much more to goal achievement than the minimum that could be extracted from them by supervisory enforcement of the (vague) terms of the employment contract. Why do employees not substitute leisure for work more consistently than they do? Why do they often work so vigorously for the welfare of the organization? (Simon, 1991: 32-33)

Free riders de fato existem, mas esta não é a polêmica, a questão é: Por que, quando há oportunidade para tanto, existe algo além de free-riding? Como vimos, o argumento de que os empregados maximizam sua utilidade ao aceitarem a autoridade da firma não é suficiente para esclarecer o ponto. Outra resposta que a teoria fornece é a de que as firmas possuem sistemas de incentivos, que dão benefícios monetários (ou outros) aos seus empregados com melhor desempenho, tornando vantajoso ao empregado agir de acordo com os desígnios da firma, fazendo coincidir, em parte, os objetivos de ambos. Simon (1991: 33; 1997a: 44) concede que tais sistemas são capazes de dar motivação aos empregados, no entanto ele aponta como condição para que os incentivos sejam bem sucedidos a possibilidade de que a contribuição individual de cada empregado possa ser medida com acuidade. Infelizmente, ocorre justamente que, quanto maior a interdependência entre determinadas atividades, maior a tendência de que sejam executadas no interior de uma mesma organização, pois a interdependência é exatamente o que torna vantajoso organizar a atividade ao invés de delegála ao mercado, mas isso também implica numa maior dificuldade de distinguir a contribuição de cada um. Segundo ele portanto, as dificuldades de realização desta medida são intrínsecas à própria natureza e à lógica das organizações. Além disso, qualquer observação extensiva e contínua do comportamento é impraticável e os conflitos e disputas internos à organização reduzem a correlação entre os incentivos recebidos e a contribuição efetiva, com o resultado 
de que os sistemas de incentivo são extremamente imperfeitos. Assim, de acordo com Simon, os estes sistemas não podem ser os únicos meios de motivação:

Although economic rewards play an important part in securing adherence to organizational goals and management authority, they are limited in their effectiveness. Organizations would be far less effective systems than they actually are if such rewards were the only means, or even the principal means, of motivation available. (Simon, 1991: 34)

Simon então busca na observação do comportamento nas organizações, em como ele se dá de fato, outras fontes de motivação, e encontra, em particular, a identificação organizacional. Os empregados - em especial, mas não apenas, aqueles em posições administrativas e/ou intelectualmente desafiadoras - sentem orgulho de seu trabalho e são leais à firma em que trabalham. De acordo com o autor, a identificação faz com que os membros da organização tomem decisões como membros dela, de acordo com os objetivos organizacionais. Isto implica que, ao tomar decisões, os empregados as avaliam em função dos objetivos da firma (em alguma medida em detrimento de, ou desconsiderando, seus próprios), o que significa que os empregados agem de forma altruísta ${ }^{149}$ para com a firma. No entanto, tanto a teoria econômica ${ }^{150}$ quanto a teoria evolucionária contemporânea nos fazem desconfiar do comportamento altruísta. Nas palavras de Simon:

Contemporary evolutionary theory has cautioned us against postulating altruistic motives for people. In models of natural selection, nice guys generally aren't fit; they don't multiply as rapidly as their more selfish brethren. The argument from natural selection has often been used, explicitly or implicitly, to fill the utility function with selfish personal goals. (Simon, 1991: 35; ver também 1997a: 39)

A despeito deste óbice, Simon sustenta que modelos de seleção natural não excluem a possibilidade, e nem mesmo a probabilidade de que as pessoas se sintam motivadas pela lealdade organizacional. Em outras palavras, o altruísmo não apenas não pode ser descartado mas deve ser esperado. Seu argumento gira em torno de um traço característico do comportamento humano, que ele denomina docilidade.

\footnotetext{
149 Altruísmo é pensado por Simon aqui numa acepção relativamente comum na economia: “Any behavior that benefits another at the expense of the benefactor's wealth is now altruistic." (Simon, 1997a: 43)

${ }^{150}$ Há muito os economistas postulam o egoísmo ou o auto-interesse dos agentes, e mais recentemente a justificativa para tal tem sido fundamentada numa teoria evolucionária "ligeira". Estes mesmos argumentos têm sido mobilizados para a defesa da hipótese de hiperracionalidade, como no artigo de Friedman (1953), caro à ortodoxia, mas cuja leitura atenta revela uma teoria evolucionária de mesa de bar.
} 
Simon (1991: 35; 1997a: 40) nota que os seres humanos são extremamente dependentes do meio social em que vivem. Na infância, a família e, mais adiante, a sociedade mais ampla fornecem às pessoas não apenas as condições materiais - comida, abrigo, segurança - mas também o conhecimento e habilidades de que necessitam para viver, sobreviver e se reproduzir. Mais do que isso, cada vez mais, a própria sociedade constitui o ambiente principal, mais do que o meio natural, ao qual os indivíduos se adaptam e, portanto, as reações da própria sociedade podem facilitar ou atrapalhar severamente as atividades de cada um. Mas dentro da sociedade a tratabilidade, a permissividade e a capacidade de aprender são características fundamentais para a adaptação ao ambiente social. São justamente estas que Simon agrega sob o conceito de docilidade:

What kinds of traits, in addition to personal strength and intelligence, would contribute to the fitness of this socially dependent creature? One such trait, or combination of traits, might be called docility. To be docile is to be tractable, manageable, and above all, teachable. Docile people tend to adapt their behavior to norms and pressures of the society. I am not satisfied that 'docile' conveys my meaning precisely, but I know of no better word. (Simon, 1991: 35) 151 $^{151}$

As pessoas, pode-se conceder sem problemas, não são totalmente dóceis, mas o argumento aqui é de que também não são totalmente egoístas. Segundo o próprio Simon (1991: 35) o cerne da questão é que o grau de adaptação (fitness) exige uma substancial, ainda que não incondicional, permissividade à influência social e à persuasão: exige docilidade. Esta permissividade pode se manifestar, a depender do contexto, como uma tendência a imitar e aprender ou como uma disposição a obedecer e se conformar. Na média a docilidade tende a ser amplamente vantajosa para os indivíduos e portanto é de se esperar que este seja um traço selecionado naturalmente entre os seres humanos. ${ }^{152}$ Simon conclui que a conseqüência disso é que os seres humanos são capazes, em pleno acordo com a teoria evolucionária, de agir de forma altruísta e, mais do que isso, tendem a apresentar esta característica:

\footnotetext{
${ }^{151}$ Note que, ao fundamentar o altruísmo na dependência individual do ambiente social, isso também constitui uma "troca". Assim o altruísmo de Simon não é exatamente estrito, e poderia ser melhor chamado de "egoísmo esclarecido".

${ }^{152}$ Simon faz relação direta entre docilidade e racionalidade restrita: "There is a close connection between bounded rationality and docility. If our computational abilities were unlimited, so that we could discover and carry out the choices mandated for the maximization of expected utility, then we would not need help from others. The farther the complexities of the real world extend beyond our capacities for knowledge and calculation, the more valuable is docility, to enable us to benefit from the collective knowledge and skill of our society - Adam Smith's division of labor in a new guise." (Simon, 1997a: 41)
} 
The purpose of the present argument is to show that this docility and the altruism it induces is wholly consistent with the premise of selection of the fittest. In fact, the theory of natural selection strongly predicts the appearance of docility and altruism in social animals. (Simon, 1991: 36)

Simon (1997a: 44) aponta, dentre todos os comportamentos altruístas, aqueles que resultam da lealdade das pessoas aos grupos a que pertencem - sejam eles a família, a cidade, a nação, grupos étnicos ou religiosos, ou organizações - como potencialmente as mais extensivas e importantes formas de altruísmo que podem ser encontradas na sociedade.

Simon enfatiza que, além do suporte motivacional, dado pela docilidade humana, há também um importante elemento cognitivo que afeta (acentua) a identificação organizacional. Conforme discutido no capítulo anterior, a racionalidade restrita dos seres humanos força-os a focar em alguns aspectos estratégicos da totalidade do mundo, formando modelos simplificados dele. A racionalidade se exerce sobre estes modelos simplificados, deixando de lado, em larga medida, o que não é por eles contemplado. Uma das manifestações desta simplificação é o foco em objetivos particulares, da qual o foco nos objetivos da firma é uma instância. A ligação do empregado à firma (e de maneira mais geral do membro à organização), constituída destes dois elementos, o motivacional e o cognitivo, é o que Simon (1997a: 45) chama de identificação organizacional.

Estabelecido este argumento, voltemos à discussão central. Simon nota que a autoridade da firma à qual os empregados se submetem e a identificação destes com os objetivos da firma fornecem importantes meios de coordenação das atividades de grupos de indivíduos, meios que dificilmente podem ser supridos pelo mercado. ${ }^{154}$

Simon (1991: 39) lembra o fato de que, como bem mostra a teoria dos jogos, em situações em que a decisão a ser tomada depende das ações, incertas, de outros agentes a ação racionalmente apropriada em geral se torna indeterminada, a despeito dos objetivos dos agentes serem complementares ou competitivos. Argumenta que, no interior da organização, a

\footnotetext{
${ }^{153}$ E também: "Docility contributes enormously to our fitness, hence has been selected by the evolutionary process, because the things we are taught or are influenced to do are generally beneficial to us. This does not mean that all of them are beneficial. In a society of docile people, individuals can sometimes be directed toward behavior that benefits the society while harming the person who engaged in it (e.g., jumping into a river or entering a burning building to rescue someone). As long as the 'tax' imposed by such behaviors is not as great as the benefit from docility, docile people, who will now also exhibit altruism, will remain fitter than selfish nondocile people." (Simon, 1997a: 41)

${ }^{154} \mathrm{Na}$ seção 4.3 explorarei estes dois mecanismos de influência organizacional, junto com outros, mais detidamente.
} 
autoridade pode resolver esta indeterminação, promulgando padrões e regras de comportamento, permitindo assim que expectativas estáveis sejam formadas. Os mercados, por si só, não possuem um mecanismo equivalente.

Além disso, Simon (1991: 41) continua, há uma diferença crucial entre os mecanismos de coordenação que operam no interior de organizações e aqueles que operam entre diferentes organizações. A coordenação entre organizações (ou entre contratantes independentes), no mercado, depende apenas e tão-somente de incentivos e motivações econômicas, enquanto no interior da organização ela também se sustenta na identificação organizacional de seus membros. Na medida em que externalidades relevantes estejam presentes o mercado não tem como se resguardar da ligação das partes a subobjetivos, enquanto no interior da organização existe a possibilidade de internalizar estas externalidades na medida em que os subgrupos se identifiquem com o objetivo da organização. Simon reforça, em particular, a identificação à redução das ineficiências advindas do "risco moral" e "oportunismo".

Assim, a autoridade proveniente da relação empregatícia e a identificação organizacional fornecem meios fundamentais para a capacidade de coordenação de atividades nas organizações e para dar suporte à sua eficiência relativamente elevada, fazendo delas alternativas funcionais aos mercados nestes aspectos, como aponta Simon:

The need for coordination, along with the possibility of creating organizational loyalties are perhaps two of the most important factors that give organizations an advantage over markets in many situations, and that account for the large role of organizations in the economic activity of a society like ours. (Simon, 1997a: 49)

Estes argumentos são mobilizados por Simon no sentido de marcar as organizações como formas de coordenação de atividades que são produtivas e eficientes, capazes de competir, no exercício desta função, com os mercados. Como evidência em favor de sua proposição o autor aponta para estudos que não encontram diferença significativa de produtividade e eficiência em diversos tipos de organização:

The plausibility of our analysis of the relative advantages of markets and organizations can be checked in a variety of ways by observing existing institutions. In those industries where private enterprise competes with government agencies (for example, water and power utilities, communication services), we can try to evaluate their relative efficiencies. A few such studies have been made, with largely inconclusive results. In some cases the private providers of services have appeared to be more efficient, in other cases the government providers. The evidence certainly provides no support for the claim that profit interests of owners are essential for efficiency. Evidently, comparable levels of 
efficiency can be attained with the help of internal economic rewards and organizational identifications. (Simon, 1997a: 49, veja também 1991: 38)

Um motivo que podemos atribuir para o fato destas diferenças não serem encontradas, na opinião de Simon, é que a produtividade, a eficiência (e o lucro quando for o caso) das organizações depende menos da motivação egoísta pela riqueza ou pelo lucro do que da autoridade e identificação organizacionais. Corolário disto é que o argumento aqui desenvolvido para o caso particular das firmas pode ser estendido para as organizações em geral. $^{155}$

Mas mais do que isso, segundo Simon, as organizações e seus meios de coordenação particulares, são estritamente necessários para o grau até onde a divisão do trabalho e a especialização foram levadas, e conseqüentemente os graus de produtividade e eficiência atingidos nas sociedades hodiernas:

We must keep in mind that the modern developed world has achieved very high levels of productivity with the aid of large-scale organizations, and would not know how to maintain that productivity without them. (Simon, 1997a: 45) 156 $^{150}$

O leitor atento há de ter notado que o argumento levantado por Simon, relativamente às organizações, é um argumento classicamente levantado pelos defensores do mercado: o de que o aprofundamento da divisão do trabalho e da especialização - possibilitado pelas trocas no caso do mercado - leva ao aumento da eficiência e da produtividade, do ponto de vista da

\footnotetext{
${ }^{155} \mathrm{Na}$ verdade o argumento original é de fato o geral. Nesta discussão Simon focaliza as firmas, talvez por estar voltado para um público de economistas, mas o argumento é feito para o caso particular das firmas sem perda de generalidade.

${ }_{156}$ Por extenso: “.... the existence and effectiveness of large organizations does depend on some adequate set of powerful coordinating mechanisms being available. These means of coordination in organizations, taken in combination with the motivational mechanisms discussed earlier, create possibilities for enhancing productivity and efficiency through the division of labor and specialization.

In general, as specialization of tasks proceeds, the interdependency of the specialized parts increases. Hence a structure with effective mechanisms for coordination can carry specialization further than a structure lacking these mechanisms. It has sometimes been argued that specialization of work in modern industry proceeded quite independently of the rise of the factory system. This may have been true of the early phases of the industrial revolution, but would be hard to sustain in relation to contemporary factories. With the combination of authority relations, their motivational foundations, a repertory of coordinative mechanisms, and the division of labor, we arrive at the large hierarchical organizations that are so characteristic of modern life." (Simon, 1991: 42)
} 
sociedade. ${ }^{157}$ Segundo a análise de Simon, o cerne da questão está no balanço entre as vantagens e desvantagens da centralização ou descentralização da tomada de decisões.

\subsubsection{Centralização e descentralização: eficiência relativa de mercados e organizações}

Simon nota que as fronteiras entre as organizações e mercados são bastante tênues e fluidas. Ao analisar as decisões de produzir-ou-comprar ele afirma que em muitos casos práticos este tipo de decisão é ambígua e, na verdade, o grau de integração das atividades numa firma está sujeito a um certo grau de arbitrariedade (ou historicidade), uma vez que em muitos casos a decisão entre uma e outra forma é praticamente indiferente. Além disso, as próprias empresas utilizam-se de "práticas de mercado" em seu interior: negociando preços de serviços prestados internamente às firmas ou tentando acompanhar o desempenho de cada subunidade. Do ponto de vista oposto, muitas firmas, ao comprarem um produto ou serviço de outra firma, trocam informações detalhadas - que vão muito além da simples informação do preço - e controlam diretamente especificações dos produtos negociados, como por exemplo (entre muitos outros) no caso dos fornecedores de autopeças (Simon, 1997a: 47-48). Tudo isso contribui ainda mais para borrar a definição da fronteira entre mercados e organizações. Nas palavras do autor:

... the system is in nearly neutral equilibrium between the use of market transactions and authority relations to handle any particular matter: that is to say, very small changes in the situation can tip the equilibrium one way or another. It is hard to explain degrees of integration of economic activities. In many instances, transaction cost analysis is not applicable, and even where it is, there often remains considerable latitude for different degrees of integration. ... Under constant returns to scale and reasonably competitive markets, which characterize many manufacturing situations, make-or-buy decisions become ambiguous. (Simon, 1991: 28-29)

Esta dificuldade de demarcação entre organização e mercados, tanto do ponto de vista teórico quanto do prático, demonstra a não trivialidade das questões envolvidas. Simon (1997a: 50) argumenta que, nas discussões recentes a respeito das vantagens do livre mercado, tem havido confusão entre duas variáveis que deveriam ser tratadas de forma independente: a forma de propriedade e a centralização ou descentralização da tomada de

\footnotetext{
${ }^{157}$ Nas palavras de Hayek: "The thesis that without the price system we could not preserve a society based on such extensive division of labor as ours was greeted with a howl of derision when it was first advanced by von Mises twenty-five years ago. Today the difficulties which some still find in accepting it are no longer mainly political, and this makes for an atmosphere much more conducive to reasonable discussion." (Hayek, 1945: 528529)
} 
decisão. A forma de propriedade, segundo Simon, é uma variável independente do grau de centralização da tomada de decisão no seguinte sentido:

A free market system makes possible a considerable decentralization of decision making if not quite such a complete decentralization as von Hayek (1945) and other neoclassical economists have claimed. But the free market sends its signals to organizations quite independently of their form of ownership. A non-profit corporation that competes in a free market must float on its own bottom just as a profit-making corporation in that same market must. Each one can only spend the funds that it raises by providing services to its clients and inducing investment in its activities. (Simon, 1997a: 50)

Seguindo o raciocínio de Simon, não seria de se esperar, portanto, grandes diferenças de eficiência e produtividade entre as diferentes formas de propriedade e controle de organizações: governamentais, sem fins lucrativos ou com fins lucrativos, administradas pelos acionistas ou não.

A variável centralização ou descentralização da tomada de decisão é decisiva para discutir duas questões: a da eficiência relativa entre organizações e mercados e a do já antigo debate entre planejamento central versus mercado. Há interseção entre as duas questões, mas coloquemos a distinção entre elas situando a questão do planejamento central no âmbito das relações entre organizações, como, aliás, ela tradicionalmente se coloca. O foco aqui é, entretanto, na eficiência relativa entre organizações e mercados.

Simon (1991, 1997a) escolhe Hayek (1945) e sua versão da defesa do livre mercado como interlocutor no debate. ${ }^{158}$ Hayek argumenta que o sistema de preços é capaz de engendrar uma enorme economia de conhecimento ao permitir a tomada de decisão descentralizada dos agentes da economia e que estes, a um só tempo, façam uso do conhecimento disperso por toda a sociedade e se ajustem ao padrão de mudanças do sistema econômico mais amplo. Segundo ele, alguma forma de descentralização é necessária, pois é só através dela que o conhecimento particular de local e momento que se encontra

\footnotetext{
${ }^{158}$ A escolha de Hayek não parece ser à toa. Em primeiro lugar, as teses de Hayek constituem, de fato, um dos mais fortes e consistentes argumentos existentes em favor do livre mercado. Em segundo lugar, há uma enorme afinidade de percepção das limitações cognitivas dos agentes econômicos entre os dois autores, estas de fato constituem um importante mote de suas teorias e de suas respectivas críticas à teoria vigente. Tome-se, por exemplo, o seguinte trecho: “... there is something fundamentally wrong with an approach which habitually disregards an essential part of the phenomena with which we have to deal: the unavoidable imperfection of man's knowledge and the consequent need for a process by which knowledge is constantly communicated and acquired. Any approach, such as that of much of mathematical economics with its simultaneous equations, which in effect starts from the assumption that people's knowledge corresponds with the objective facts of the situation, systematically leaves out what is our main task to explain." (Hayek, 1945: 530, negrito: ênfase minha, itálico: ênfase original). March e Simon (1958: 203-204) reconhecem esta afinidade explicitamente.
} 
necessariamente disperso pela sociedade pode ser utilizado. Mais do que isso, a utilização apropriada deste conhecimento é o problema econômico fundamental:

If we can agree that the economic problem of society is mainly one of rapid adaptation to changes in the particular circumstances of time and place, it would seem to follow that the ultimate decisions must be left to the people who are familiar with these circumstances, who know directly of the relevant changes and or the resources immediately available to meet them. We cannot expect that this problem will be solved by first communicating all this knowledge to a central board which, after integrating all knowledge, issues its orders. We must solve it by some form of decentralization. (Hayek, 1945: 524)

Ainda segundo Hayek (1945), o sistema de preços, que opera no mercado, é o que permite a coordenação das ações de diferentes pessoas. Ele afirma que sistema de preços condensa toda a informação relevante para os ajustes das atividades econômicas das pessoas, pois ele informa quão mais fácil ou difícil se tornou o fornecimento de um determinado bem, ou quão mais ou menos procurados são os bens que elas produzem, desconsiderando as causas destas mudanças.

Como Simon nota, Hayek não fala em otimização, apenas em ajustes. Simon (1997a: 37) concorda que os preços sejam indicadores cruciais para ajustes de curto prazo, no entanto outros indicadores são tão ou mais importantes quanto os preços, em particular indicadores de quantidades: os estoques e as encomendas (backlog of orders). Segundo Simon, os ajustes por quantidades são no geral, inclusive, mais eficazes:

Coordination by adjustment of quantities is probably a far more important mechanism from a day-to-day standpoint, and in many circumstances will do a better job of allocation than coordination by prices. (Simon, 1991: 40)

Mais do que isso, os preços dizem pouco a respeito da adequação dos ajustes a prazos mais longos: os preços podem dizer quando o sistema está operando dentro de limites aceitáveis, mas caso não esteja, eles trazem pouca (embora importante, é claro) informação sobre o porquê não está ou sobre o que fazer a respeito. Preços, estoques e encomendas permitem ajustes do volume de produção e do preço praticado no curto prazo através de mecanismos simples de feedback:

The common and understandable practice of pricing by marking up costs assures liquidity, at least in the short run, if only there is at least a modest base of fixed costs. The adjustment of production rates to sales holds price margins within a moderate range without excessive absorption of cash by inventories. All of this has little or nothing to do with the usual theorems of optimal pricing and production rates. A simple feedback of price, inventories and sales information adjusts production and prices and maintains a 
tolerable steady state over considerable intervals of time without any close calculation of margins or optima. (Simon, 1997a: 37)

Como discutido acima, ao considerarmos os relacionamentos entre firmas, em muitos casos a informação trocada entre elas vai muito além do preço. Mesmo contratos travados entre elas especificam muito mais do que preços e quantidades. Durante a negociação e execução, grandes volumes de informação são trocados, indo muito além do "quão mais fácil ou difícil se tornou o fornecimento de um determinado produto", como bem aponta Simon:

Thus, the assertion that markets permit each firm to do its own business with little knowledge of its partners is a fiction. In construction, in heavy industry, in manufacturing involving high technology, and in other areas, contracting partners carry on communication at a level comparable to the levels observed between departments of a firm. (Simon, 1991: 41)

Resultado disso é que, mesmo em se tratando dos ajustes rotineiros num "mundo em constante mudança", os sinais de preço não são as únicas fontes de informação disponíveis e, mais importante que isso, eles certamente não concentram "toda a informação relevante" como pretende Hayek. ${ }^{160}$ Do ponto de vista de Simon (1991: 40), os preços são apenas um dos mecanismos de coordenação de comportamento, entre organizações ou dentro delas.

Simon avança ainda e aponta que estes ajustes rotineiros estão distantes de perfazer todas as decisões economicamente relevantes. As atividades de projeto (design) de produtos, estratégias, processos e outras mencionadas acima envolvem procedimentos de busca e informação qualitativa e quantitativamente distinta daquela que o sistema de preços pode fornecer. Nas palavras do autor:

Nor does this self-adjusting system have much to do with the information that the firm must gather in order to carry out the numerous search and design activities mentioned earlier. A study of the allocation of management time would almost certainly show that it

\footnotetext{
${ }^{159}$ O próprio Hayek não ficou tão longe assim de dizer isso: "Of course, these adjustments are probably never 'perfect' in the sense in which the economist conceives of them in his equilibrium analysis. But I fear that our theoretical habits of approaching the problem with the assumption of more or less perfect knowledge on the part of almost everyone has made us somewhat blind to the true function of the price mechanism and led us to apply rather misleading standards in judging its efficiency. The marvel is that in a case like that of scarcity of one raw material, without one order being issued, without more than perhaps a handful of people knowing the cause, tens of thousands of people whose identity could not be ascertained by months of investigation, are made to use the material or its products more sparingly; i.e., they move in the right direction. This is enough of a marvel even if, in a constantly changing world, not all will hit it off so perfectly that their profit rates will always be maintained ate the same constant or 'normal' level." (1945: 527)

${ }^{160}$ Hayek faz esta afirmação no que se refere a "pequenas mudanças". Esta ressalva é pouco enfatizada por ele e por outros que o seguiram, até porque fica difícil justificar a defesa incondicional do livre mercado se ele é suficiente apenas para pequenos ajustes.
} 
is the latter that account for most of the managers' days, not the effortless adjustment to price signals that von Hayek mentions. (Simon, 1997a: 37$)^{161}$

Ainda outras considerações são pertinentes. Simon argumenta que a incerteza dos preços é outro fenômeno que faz pender a balança para os mecanismos organizacionais de coordenação. Segundo ele, seguindo o argumento de Hayek até suas conseqüências lógicas teremos que, quanto mais complexa a situação, maiores seriam as vantagens do sistema de preços sobre o planejamento central. Assim, a passagem de uma economia para uma situação de guerra seria um bom teste para a teoria. No entanto, justamente nestes momentos ocorre uma maior centralização das decisões. ${ }^{162}$ Para Simon a resposta é simples: a incerteza impede o sistema de preços de exercer sua função adequadamente:

The answer is rather obvious. Prices perform their informational function when they are known and reasonably predictable. Uncertain prices produced by unpredictable shifts in a system reduce the ability of actors to respond rationally. This point is often made by economists in arguing the costs of unexpected inflation, but its implication for the choice between organizations and markets is less often noted. Nor is it noted that many kinds of uncertainties other than price uncertainties may make coordination through organizational procedures advantageous. (Simon, 1991: 40)

Se o argumento de Hayek é bastante robusto ao ressaltar as deficiências (ou a impossibilidade prática) do planejamento central total, apontando para a descentralização, ele não sustenta, no extremo oposto, a descentralização total das decisões. Primeiro, se a descentralização é necessária para o aproveitamento do conhecimento particular de local e momento, este tipo de conhecimento não é todo o conhecimento relevante às decisões econômicas. Um exemplo óbvio pode ser encontrado nos especialistas e no conhecimento que detêm. Um tradeoff entre centralização e descentralização se coloca de imediato entre o uso destes dois tipos de conhecimento, um intrinsecamente disperso e o outro necessariamente concentrado. Em segundo lugar, o argumento só se aplica na medida em que a complexidade da situação seja tal que não permita que ela seja tratável de forma minimamente adequada por uma pessoa, como no caso do planejamento central. No entanto, as situações organizacionais em que os agentes se colocam são em geral "tratáveis", no sentido de que uma boa solução

\footnotetext{
${ }^{161}$ Nesses importantes casos, antes de escolher entre alternativas, é preciso gerar alternativas: “... we must recognize that choosing among a fixed set of alternative actions - and these mainly limited to the quantities of various products that will be produced - constitutes only a small, and relatively uninteresting part of the decision-making task within firms. Business managers are mainly occupied with a wide range of what I have called design tasks - design of products and of strategies of marketing, finance, manufacturing, and so on - and the success of a business depends largely on how well these tasks are performed." (Simon, 1997a: 51)

${ }^{162}$ Para mais detalhes sobre esta discussão veja March e Simon (1958: 203-208).
} 
pode ser atingida. Neste sentido, o trecho abaixo pode ser lido, com intenções outras que as do autor, como uma declaração do próprio Hayek de que algum grau de centralização é pertinente:

There would be no difficulty about efficient control or planning were the conditions so simple that a single person or board could effectively survey all the relevant facts. It is only as the factors which have to be taken into account become so numerous that it is impossible to gain a synoptic view of them, that decentralization becomes imperative. (Hayek apud March e Simon, 1958: 203)

Além disso, como foi visto, o sistema de preços não é o único mecanismo de coordenação para a atividade descentralizada - a autoridade e a identificação organizacional são outros - e não será sempre o melhor, como no caso de presença de externalidades significativas. Dois outros fatores são decisivos neste tênue equilíbrio: a interdependência entre as ações dos indivíduos, no sentido de que a ação apropriada para uma determinada situação depende da ação de outros; e o tipo e a quantidade de comunicação necessária para diferentes arranjos de uma mesma atividade (Simon, 1997a: 52).

Ressaltada a importância do papel das organizações enquanto mecanismos de coordenação do comportamento, seguirei para uma análise mais detalhada das formas pelas quais a organização pode influenciar o comportamento. Antes, porém, cabe analisar os usos que Simon faz do conceito de "organização".

\subsection{Nota sobre o conceito de organização}

Como sugeri no segundo capítulo, a definição e o uso feito por Simon do conceito de organização são bastante fluidos. O conceito de organização é um conceito formal, mais no sentido de estrutural do que de rigoroso, e é aplicado à diferentes realidades a partir de recortes destas. Estes recortes não são totalmente arbitrários, mas são bastante flexíveis. Correspondem ao que Simon (1996b: 184) chama de subsistema. As características importantes dos subsistemas, tais como Simon os pensa, são duas: primeiro, o subsistema compreende um conjunto de interações significativas e, segundo, o subsistema deve ser em alguma medida "isolado", ou seja, que o conjunto de interações no subsistema seja mais relevante do que as interações entre os diferentes subsistemas, ou seja, que as interações 
dentro do subsistema sejam significativamente mais intensas do que entre os subsistemas. ${ }^{163}$ Associando esta idéia de subsistema a grupos sociais temos as organizações. Assim, explorando as possibilidades lógicas do conceito, uma organização pode ser uma família, uma firma, um clube, uma cidade, uma sociedade inteira etc. Simon, ao menos explicitamente, faz uso do conceito de maneira mais próxima do senso comum, mas sempre explora brechas da generalidade e do grau de abstratividade do conceito.

Uma destas "brechas" mais utilizadas é a de se pensar a sociedade como uma organização: Simon faz isso implicitamente de forma regular. O argumento explícito usado por ele é o de que suas proposições são válidas ou relevantes para uma teoria das organizações, mas a definição adotada para este conceito é bastante ampla, quase confundindo-se com outros como o de instituição social, no sentido de um padrão regular (pattern) de relações num determinado grupo social. Na definição do autor:

In the pages of this book, the term organization refers to the complex pattern of communication and relationships in a group of human beings. This pattern provides to each member of the group much of the information and many of the assumptions, goals, and attitudes that enter into his decisions, and provides him also with a set of stable and comprehensible expectations as to what the other members of the group are doing and how they will react to what he says and does. (Simon, 1976a: xvii)

O próprio argumento de que as organizações fornecem estabilidade ao ambiente decisório dos agentes é muito semelhante ao institucionalista. Os termos organização e instituição são eventualmente, embora não freqüentemente, utilizados de forma análoga ou equivalente. ${ }^{164} \mathrm{~A}$ intenção parece ser, de fato, a de deixar fluida a fronteira daquilo que deve ser incluído no conceito de organização. Tanto em Simon $(1947,1976 a)$ quanto em March e

\footnotetext{
${ }^{163}$ Uma analogia pode deixar isso menos árido. O conteúdo de um copo de água é composto por um conjunto de moléculas do elemento. As forças intramoleculares (a "interação") são muito, ordens de grandeza, superiores às forças intermoleculares. Cada molécula de água pode, então, ser entendida como um subsistema do "copo". Cada molécula pode ter o seu comportamento estudado, e previsto de forma aproximada, quase isoladamente, bastando para tanto conhecimento sobre o comportamento agregado do copo. Por outro lado, cada molécula é composta por três átomos e, mais uma vez, as forças intraatômicas são ordens de grandeza maiores que as interatômicas. Assim, cada átomo pode ser entendido como um subsistema da molécula. Cada átomo é composto de elétrons, prótons e nêutrons. E assim por diante. E no outro sentido também poderíamos seguir: molécula, célula, tecidos, órgãos, organismo etc. O subsistema constitui uma subdivisão "natural" do sistema. O ponto crucial é que Simon (1996b) entende que este tipo de organização, que ele chama de hierárquica, é característica bastante geral do mundo em que vivemos. Em particular aqui, é aplicada às organizações.

${ }^{164}$ Como no seguinte trecho: "It was mentioned several times in this chapter that the mechanisms leading to the integration of behavior might be interpersonal. If organizations and social institutions be conceived, in the broad sense, as patterns of behavior, it is not hard to see that the individual's participation in such organizations and institutions may be the source of some of the most fundamental and far-reaching integrations." (Simon, 1947: 100)
} 
Simon (1958) o objeto de estudo explícito é o comportamento no interior de organizações. No entanto, o único trecho nestas duas obras que encontrei voltado à distinção entre organização e sociedade atesta que a diferença está na especificidade das influências exercidas no interior de uma organização, quando comparado com a difusão delas fora da organização. ${ }^{165}$ Há que se notar, no entanto, que esta é uma distinção apenas relativa, que não altera a qualidade das coisas: a diferença é apenas de grau. Processos de influência na sociedade podem ser analisados pela mesma estrutura teórica, e afinal de contas, por que uma sociedade não poderia ser vista como "um padrão complexo de comunicações e relações em um grupo de seres humanos"?

De fato, quando Simon (1976a) contrapõe sua teoria com teorias sociológicas, ele escolhe duas teorias bastante gerais: a teoria da ação social, de Talcott Parsons, e a teoria dos papéis (role theory), e as ataca num plano bastante geral, alegando que nem uma ação, e nem um papel são unidades adequadas de análise para uma teoria comportamental. ${ }^{166}$ Como vimos acima ele advoga a premissa, unidade mais fina, como mais adequada. Neste sentido, acredito que podemos entender a teoria das organizações de Simon como tendo pretensões de teoria social ou comportamental mais geral, embora isso seja raramente explicitado. Acredito que o melhor exemplo da pretensão de generalidade da teoria comportamental de Simon se encontra na coletânea de artigos Models of man, social and rational, em seu prefácio consta o seguinte:

For when these essays are viewed in juxtaposition, it can be seen that all of them are concerned with laying foundations for a science of man that will accommodate comfortably his dual nature as a social and a rational animal. (Simon, 1957: vii, ênfase minha)

Assim, essa generalidade do conceito de organização ajuda a explicar também a flexibilidade da teoria comportamental de Simon a diferentes contextos, conforme discutido anteriormente. Tendo estas considerações em mente, podemos agora analisar os mecanismos de influência organizacional que engendram, como já disse, o contexto no qual o comportamento se dá.

\footnotetext{
165 "If we wished to sum up in a single quality the distinctive characteristics of the influence processes in organizations, as contrasted with many other influence processes of our society, we would point to the specificity of the former as contrasted with the diffuseness of the latter." (March e Simon, 1958: 2-3)

${ }^{166}$ Alguns anos antes, no entanto, Simon (1963) tentou vestir sua teoria como uma versão melhorada da teoria dos papéis.
} 


\subsection{Influência organizacional sobre o comportamento}

Esta seção é dedicada a detalhar os mecanismos de influência organizacional, que como vimos na primeira seção deste capítulo, têm um papel fundamental na capacidade das organizações de coordenar o comportamento. É a análise destes mecanismos que traz especificidade à teoria, reduzindo (um pouco) seu grau de abstratividade, ao tratar de questões mais palpáveis. Isto significa - que fique claro desde o princípio - uma incursão na seara da administração. Falamos muito da importância de entender como as decisões são efetivamente tomadas, dos processos de decisão empregados. No interior das organizações, na prática, a figura que toma muitas das decisões mais relevantes é o administrador.

Uma importante percepção de Simon ao analisar o comportamento humano é que, no processo de decisão, apesar do ambiente subjetivo de escolha ser necessariamente simplificado a ponto de ser tratável pela mente humana, ele não é determinado de maneira casual. Pelo contrário, se é impraticável aproximar-se da racionalidade objetiva tornando o ambiente subjetivo mais próximo do objetivo em função das limitações cognitivas do decisor, é possível fazê-lo pelo controle do próprio ambiente de escolha. Se no interior de organizações formais o ambiente pode ser deliberadamente escolhido e modificado, no âmbito mais geral da sociedade ele é tudo menos aleatório, como aponta Simon:

If the psychological environment of choice, the 'givens,' were determined in some accidental fashion, then adult behavior would show little more pattern or integration than the behavior of children. A higher degree of integration and rationality can, however, be achieved, because the environment of choice itself can be chosen and deliberately modified. (Simon, 1947: 79)

Do ponto de vista da teoria comportamental de Simon, uma vez que a racionalidade apresenta um caráter intrinsecamente subjetivo e relativo, e que o ambiente de decisão é, por força maior, relativamente simples, a determinação das premissas contidas nele passam a ser uma questão crucial. $O$ ambiente organizacional e social tem um papel central na determinação do ambiente subjetivo de decisão. Ele é influência preponderante no que diz respeito a quais conseqüências são antecipadas, a quais alternativas são consideradas e ao sistema de valores utilizado na valoração (March e Simon, 1958: 139). A influência das organizações e da sociedade sobre as decisões individuais deve ser entendida, portanto, como 
algo que incrementa, ou até mesmo possibilita, a racionalidade nas decisões. ${ }^{167}$ Mais do que isso, Simon nos lembra que é difícil sequer pensar em racionalidade fora de um contexto organizacional ou institucional:

The behavior patterns which we call organizations are fundamental, then, to the achievement of human rationality in any broad sense. The rational individual is, and must be, an organized and institutionalized individual. If the severe limits imposed by human psychology upon deliberation are to be relaxed, the individual must in his decisions be subject to the influence of the organized group in which he participates. His decisions must not only be the product of his own mental processes but also reflect the broader considerations to which it is the function of the organized group to give effect. (Simon, 1947: 102)

O controle do próprio ambiente psicológico de decisão pode ser - e é - realizado individualmente. De fato, isto é uma implicação da idéia da hierarquia de decisões discutida no capítulo anterior. Uma decisão mais geral, hierarquicamente superior, por parte de uma pessoa, entre outras coisas, supre parte das premissas que serão utilizadas nas decisões subseqüentes, controlando, portanto, o ambiente decisório destas. No entanto, este é o artifício por excelência utilizado pelas organizações formais para dar coerência às atividades de seus membros. ${ }^{168}$ A maior importância da organização, do ponto de vista de uma teoria comportamental, resulta justamente da influência exercida sobre o comportamento pelo ambiente organizacional, como enfatiza Simon:

Organization is important, first because organizational environments provide much of the force that molds and develops personal qualities and habits. Organization is important, second, because it provides those in responsible positions the means for exercising authority and influence over others. Organization is important, third, because, by structuring communications, it determines the environments of information in which decisions are taken. We cannot understand either the 'input' or the 'output' of the executive without understanding the organization in which he works. His behavior and its effect on others are functions of his organizational situation. (Simon, 1976a: xvii; ver também 1947: 100-101)

No esforço de Simon para lançar as bases para uma teoria da administração, que aparece principalmente em Administrative Behavior (Simon, 1947), mas também em Organizations

\footnotetext{
167 "It is impossible for the behavior of a single, isolated individual to reach any high degree of rationality. The number of alternatives he must explore is so great, the information he would need to evaluate them so vast that even an approximation to objective rationality is hard to conceive." (Simon, 1947: 79)

${ }^{168}$ Como aponta o autor: "Partly this is an individual matter: the individual places himself in a situation where certain stimuli and certain items of information will impinge on him. To a very important extent, however, it is an organizational matter. One function that organization performs is to place the organization members in a psychological environment that will adapt their decisions to the organization objectives, and will provide them with the information needed to make these decisions correctly." (Simon, 1947: 79)
} 
(March e Simon, 1958), uma das problemáticas centrais é justamente a de fornecer os meios, a partir do conhecimento do funcionamento efetivo das organizações, para controlar os fluxos de premissas no interior das mesmas no sentido de alcançar graus mais elevados de racionalidade (do ponto de vista do objetivo organizacional). Neste ponto a finalidade prática se alia aos objetivos descritivos da teoria, tanto é que "Administrative Behavior é um livro para observadores de organizações e para desenhistas [designers] de organizações." (Simon, 1976a: ix).

Muitas das considerações nesta seção farão mais sentido quando pensadas para as organizações formais (no sentido comum da expressão), mas entendo que levá-las ao plano mais geral que discutimos na seção anterior seja uma questão de ajustes e não de impossibilidade. Além disso, embora as organizações formais sejam caso particular, é difícil exagerar a importância do comportamento enquanto no seu interior. Uma grande parte, talvez a maior, da vida desperta das pessoas é gasta no interior de organizações formais: o trabalho, a escola etc.

Mas a influência organizacional não deve ser pensada de forma simplista. Se o comportamento individual no interior das organizações é influenciado de maneira determinante pela organização, a própria estrutura organizacional é resultado do comportamento individual em dois importantes sentidos.

March e Simon (1958: 170) definem estrutura organizacional como aqueles aspectos do comportamento na organização que são relativamente estáveis, que mudam apenas lentamente. A existência de algo que possamos chamar de uma estrutura organizacional é justamente resultado das limitações cognitivas dos indivíduos. A questão é que o comportamento é adaptativo, a cada momento, relativamente a apenas alguns aspectos do ambiente. Os autores argumentam que a existência da estrutura é resultante da adaptação ser sempre parcial:

Organization will have structure, as we have defined the term here, insofar as there are boundaries of rationality - insofar as there are elements of the situation that must be or are in fact taken as givens, and that do not enter into rational calculations as potential strategic factors. (March e Simon, 1958)

Em outras palavras, organizar-se é um meio conducente através do qual indivíduos restritamente racionais podem levar a cabo seus objetivos. O segundo sentido que o autor menciona é o de que a estrutura organizacional é resultante de um conjunto de decisões gerais 
a que ele agrupa sob o termo planejamento. A atividade de planejamento consiste num tipo de decisão geral que tenta estabelecer critérios de base para a escolha em um problema recorrente. É, portanto, uma decisão que orienta decisões futuras semelhantes entre si. $\mathrm{O}$ planejamento pode, no que se refere àquele tipo de situação decorrente do problema que se repete, selecionar valores particulares como critérios para decisões futuras, apontar o conhecimento relevante para tomar aquelas decisões, e pré-selecionar alternativas comportamentais particulares como as únicas a serem consideradas (Simon, 1947: 97-98). Segundo Simon (1947: 96), o processo de planejamento envolve duas etapas. Primeiro, um conjunto de decisões amplas são tomadas, relativas a objetivos, às linhas gerais dos métodos a serem utilizados, ao conhecimento, habilidade e informação necessários. Segundo, são idealizados e implementados mecanismos que farão com que a atividade do dia-a-dia se conforme ao plano geral delineado na primeira etapa. Estes mecanismos envolvem, basicamente, o controle do ambiente de decisão, através, por exemplo, da direção da atenção e da canalização de informação. Desta maneira é possível controlar as atividades para se conformarem a um plano de ação mais geral. Cabe notar que a atividade de planejamento é um tipo de atividade que chamamos (Simon chama) anteriormente de design, de projeto, e portanto é melhor pensada como solução de problemas do que como tomada de decisão. $\mathrm{Na}$ visão de Simon, a integração do comportamento no interior da organização depende, portanto, da existência de um plano de ação geral, e também da aceitação deste plano por parte dos membros (Simon, 1947: 124).

De acordo com Simon (1947: 100-101), a influência exercida pela organização sobre seus membros se encaixa em dois tipos abrangentes. Primeiro, as organizações possibilitam que qualquer de seus membros forme expectativas estáveis sobre o comportamento dos demais em situações específicas. Segundo, elas fornecem estímulos - objetivos intermediários - e direcionam a atenção de seus membros, permitindo assim uma canalização dos comportamentos.

Os meios utilizados pela organização para influenciar as decisões de seus membros são diversos (Simon, 1947: 102-103): a organização constitui uma divisão de trabalho entre os seus membros; a organização estabelece práticas padronizadas, tendo assim ganho de escala em situações repetitivas; organizações estabelecem sistemas de autoridade e influência permitindo a transmissão de decisões; criam também canais de comunicação sistemáticos, provendo informação para a tomada de decisões; e, finalmente, as organizações treinam e 
doutrinam seus membros, fornecendo a eles conhecimento, habilidade e identificações e lealdades que são internalizadas, inculcadas, permitindo que eles tomem, por si mesmos, as decisões tais como a organização gostaria que tomassem.

Embora a flexibilidade seja ampla, naturalmente a influência exercida pela organização sobre seus membros não pode induzir comportamentos totalmente arbitrários, como percebe Simon:

No pattern of social behavior could survive, of course, that did not anticipate and provide in some manner for the satiation of the stimuli of hunger, sexual desire, and fatigue. Beyond this, institutional arrangements are subject to infinite variation, and can hardly be said to follow from any innate characteristics of man. Since these institutions largely determine the mental sets of the participants, they set the conditions for the exercise of docility, and hence of rationality in human society. (Simon, 1947: 101)

Trataremos agora dos principais modos de influência organizacional: a autoridade, a comunicação, os programas de execução, e a identificação ou lealdade organizacional. Discutiremos também o critério de eficiência, que aparece apenas em Simon (1947) como um importante modo de influência organizacional e que, como argumentarei, resulta distinto dos demais. Antes disso, porém, cabe discutir a decisão de participar da organização por parte dos seus membros, ou seja, os fatores que levam uma dada organização a existir.

\subsubsection{O equilíbrio da organização}

A teoria do equilíbrio organizacional proposta por Simon (1947) - baseada nas idéias de Chester Barnard - tenta responder quais são as condições de sobrevivência de uma organização ou, em outras palavras, porque seus membros decidem participar dela. ${ }^{169} \mathrm{~A}$ decisão de cada membro participar da organização é resultado de suas motivações pessoais: ele se torna e se mantém membro da organização na medida em que percebe que o balanço entre o que ele oferece à organização (suas contribuições) e o que recebe dela (suas induções) é vantajoso do ponto de vista dos seus valores e informação. A organização é vista como um sistema em equilíbrio, e se mantém em existência na medida em que provê um arranjo que

\footnotetext{
169 A teoria é denominada "the Barnard-Simon theory of organizational equilibrium" em March e Simon (1958:
} 84). 
torna este balanço positivo para um determinado número de pessoas (Simon, 1947: 110111). ${ }^{170}$

Assim, na teoria organizacional de Simon, uma organização é um grupo de pessoas reunidas pela possibilidade de realização de seus objetivos pessoais, direta ou indiretamente, através da organização. As induções fornecidas pela organização para um grupo é suprida pelas contribuições de outros grupos de participantes. As induções oferecidas pela organização a seus membros por sua participação se encaixam em três categorias: o próprio objetivo da organização, ${ }^{171}$ a conservação e o crescimento da organização, ou incentivos não relacionados com nenhum destes anteriores (Simon, 1947: 122). Numa empresa, por exemplo, grosso modo, poderíamos incluir os clientes na primeira, os empresários e os investidores na segunda, e os empregados e fornecedores na terceira. Mas a distinção é significativa para qualquer tipo de organização. ${ }^{172}$ Segundo o autor estes perfazem os três tipos básicos de motivação para a participação:

The characteristics of these three bases for participation are sufficiently distinct to make it worth while to consider them separately: personal rewards deriving directly from the accomplishment of the organization objective; personal inducements offered by the organization and closely related to its size and growth; and personal rewards derived from inducements offered by the organization but unrelated to the organization size and growth. Organizations are ordinarily made up of three groups of individuals, in each of which one of these types of motivation prevails; and it is the presence of these three groups that gives administration its specific character. (Simon, 1947: 110-111)

A existência da organização depende da sua habilidade em garantir a realização dos propósitos pessoais dos participantes, no entanto, isso não quer dizer que as atividades no

\footnotetext{
${ }^{170}$ Os postulados e definições básicos se concentram em torno desta idéia, e são assim expostos pelo autor em texto conjunto: "1. An organization is a system of interrelated social behaviors of a number of persons whom we shall call the participants in the organization. 2. Each participant and each group of participants receives from the organization inducements in return for which he makes to the organization contributions. 3. Each participant will continue his participation in an organization only so long as the inducements offered him are as great or greater (measured in terms of his values and in terms of alternatives open to him) that the contributions he is asked to make. 4 . The contributions provided by the various groups of participants are the source from which the organization manufactures the inducements offered to participants. 5. Hence, an organization is 'solvent' - and will continue in existence - only so long as the contributions are sufficient to provide inducements in large enough measure to draw forth these contributions." (apud March e Simon, 1958: 84)

${ }^{171}$ Dada a discussão, acredito ser necessário definir mais adequadamente "o objetivo da organização". Cada grupo de participantes contribui para a organização por motivos próprios; os clientes, em particular, pelo serviço prestado. Simon adota, por conveniência terminológica, o objetivo de serviço como o objetivo da organização (1947: 113). De qualquer maneira, o uso corresponde ao uso ordinário da expressão.

172 'Granted that pure 'entrepreneurs,' 'customers,' and 'employees' do not exist; granted further that this scheme needs to be modified somewhat to fit voluntary, religious, and governmental organizations, still it is the
} 
interior das organizações não estejam orientadas por objetivos organizacionais, como ressalta Simon (1947: 17): "Numa organização como a agora descrita, aparece, além das aspirações dos participantes, um objetivo, ou objetivos, da organização."

Simon ressalva que isso não quer dizer, todavia, que o objetivo organizacional esteja desvinculado dos objetivos pessoais dos participantes. Primeiro, há sempre um grupo que deriva a motivação da sua participação na organização diretamente do objetivo organizacional, portanto o objetivo organizacional deverá, sempre, corresponder ao objetivo pessoal de pelo menos algum grupo de pessoas. Segundo, um compromisso deverá ser atingido com os demais participantes no sentido de se manter o balanço de induçõescontribuições, no sentido de sustentar a continuidade da existência da organização. Este processo está freqüentemente sujeito a pressões resultantes de alterações das condições internas e externas à organização, causando potencialmente conflitos e barganha. Daí conclui o autor:

Hence, although it is correct to say that organization behavior is oriented toward the organization objective, this is not the whole story; for the organization objective itself changes in response to the influence of those for whom the accomplishment of that objective secures personal values. (Simon, 1947: 114)

Sempre há, no entanto, uma diversidade de arranjos, associados a distintos objetivos organizacionais (ou não organizacionais), que dão condições para a sustentabilidade da organização (March e Simon, 1958: 109).

\subsubsection{A relação empregatícia}

Simon (1947: 115) afirma que a relação que o empregado tem com a organização difere da que o cliente ou o empresário têm, no sentido de que ela não é motivada pela organização em si - pelo seu objetivo, sua conservação, ou crescimento - mas sim por compensações outras (monetárias, de status, etc) dadas em troca de seu tempo e esforço indiferenciado. Neste arranjo contratual, o empregado, ao entrar na organização, se subordina a uma relação de autoridade para com ela: ele aceita, dentro de alguns limites, se comportar de acordo com premissas (decisões, ordens, instruções) fornecidas pela organização. Como discutimos acima, a aceitação da autoridade organizacional pelo empregado dá à organização um meio poderoso 
de influenciar o comportamento dos membros, pois não é necessário utilizar-se da persuasão para influenciá-lo, apenas o consentimento. Mas convém olharmos a decisão de participar da organização por parte do empregado de forma mais detalhada.

A aceitação à autoridade organizacional não é ilimitada. Simon postula uma zona de aceitação, às vezes chamada também de "zona de indiferença", onde o exercício desta autoridade não é problemático. Um empregado achará vantajoso participar de um contrato deste tipo na medida em que não se importe muito com as atividades que porventura possa vir a ser instruído a fazer pela organização, dentro dos limites acordados no contrato, ou se as induções oferecidas pela organização forem suficientes para compensá-lo por eventuais dissabores, ou uma composição de ambos. Para a organização será interessante estabelecer uma relação de autoridade sempre que não puder prever com precisão, no momento do estabelecimento do contrato, que atividades serão necessárias para a persecução dos objetivos organizacionais (March e Simon, 1958: 91). Na análise de Simon:

The employment contract results in the creation of a continuing authority relation between the organization and the employee.

How can this be? Why does the employee sign a blank check so to speak, in entering upon his employment? First, from the viewpoint of the organization, nothing would be gained by offering an inducement to the employee unless the latter's behavior could be brought into the system of organization behavior through his acceptance of its authority. Second, from the viewpoint of the employee, the precise activities with which his time of employment is occupied may, within certain limits, be a matter of relative indifference to him. If the orders transmitted to him by the organization remain within these limits of acceptance, he will permit his behavior to be guided by them. (Simon, 1947: 116)

Simon (1979a: 502) conclui que uma das principais vantagens do contrato de trabalho é permitir que a especificação das ações particulares a serem executadas pelo empregado seja adiada até que a incerteza inerente a elas seja resolvida.

Como foi discutido acima, os empregados, como as outras classes de participantes, na medida em que se tornem e se mantenham como membros da organização também se identificam com ela, além de se submeterem à sua autoridade. Mas este ponto será analisado mais detidamente adiante.

Neste item exploramos porque os membros da organização aceitam a influência organizacional. Seguiremos tratando agora dos modos de influência organizacional, de como esta influência se dá. Lembrando que a decisão pode ser pensada como uma conclusão tirada a partir de premissas, é interessante perceber que a influência da organização sobre seus 
membros resulta na determinação de algumas das premissas envolvidas numa decisão particular e não da decisão como um todo. Assim, os diferentes modos de influência não se excluem, podendo agir simultaneamente numa mesma decisão ao atuar sobre diferentes conjuntos de premissas.

\subsubsection{Autoridade}

Segundo Simon, a autoridade é o modo de influência que mais caracteriza o comportamento no interior de organizações (formais) como distinto do comportamento fora delas. A estrutura formal da organização é uma manifestação das linhas de autoridade (Simon, 1947: 124). No comportamento em grupo, geralmente, a coordenação do comportamento dos diversos membros não é garantida espontaneamente: no mínimo a comunicação de alguns aspectos do plano é necessária. Quando a coordenação vai além da comunicação, ela tipicamente envolve, em alguma medida, o exercício da autoridade (Simon, 1947: 151). Segundo ele, quando as exigências por coordenação são pouco mais do que mínimas, a autoridade é um mecanismo necessário para garanti-la:

An analysis of organized behavior of all sorts will demonstrate that such behavior results when the coordinated individuals sets for himself a criterion of choice that makes his own behavior dependent upon the behavior of others. In the simplest cases he makes his own decision at each point as to what those adjustments should be. In slightly more complex forms of organization, he sets himself a general rule which permits the communicated decision of another to guide his own choices (i.e. to serve as a premise of those choices) without deliberation on his own part on the expediency of those premises. (Simon, 1947: 125)

A autoridade é definida por Simon (1947: 11-12, 125-126, 146, 151-152) a partir do comportamento do subordinado. Quando este aceita como premissas de sua decisão, sem avaliar por si mesmo a propriedade destas, relaxando suas próprias faculdades críticas, decisões comunicadas por outra pessoa, há exercício de autoridade sobre ele, ele se submete à autoridade. A relação de autoridade (distinta do exercício dela) se define, no entanto, entre um superior e um subordinado (Simon, 1947: 125-126). O superior toma e transmite decisões com a expectativa de que sejam obedecidas, enquanto o subordinado espera tais decisões e está disposto a obedecê-las dentro de sua área de aceitação, seu comportamento é assim determinado por elas. A relação de autoridade é definida como o poder institucionalizado de tomar decisões que guiam o comportamento alheio, e sua característica peculiar é que o superior não necessita convencer o subordinado, apenas obter sua aquiescência. 
É interessante observar que, assim definido, o conceito de autoridade não coincide com o uso comum da palavra, ela tem aqui sentido mais amplo. A autoridade pode ser exercida tanto "de cima para baixo", quanto "para os lados", quanto "de baixo para cima", o que não quer dizer, no entanto que não existam relações formais de autoridade. As linhas formais de autoridade da organização, que correspondem em larga medida à estrutura formal da mesma, podem ser entendidas também como o "direito à última palavra". Estas linhas de autoridade permitem que, numa situação de conflito, uma decisão seja transmitida e utilizada como base em outras decisões mesmo quando não se atingiu um acordo a respeito dela (Simon, 1947: $129,152)$.

Como comentado acima, este elemento arbitrário da relação entre superior e subordinado tem limites. O subordinado aceitará um comando como base para seu comportamento apenas se este imperativo estiver na sua zona de aceitação - se estiver fora dela haverá desobediência. A amplitude da zona de aceitação dependerá das sanções disponíveis ao superior para impor a autoridade (Simon, 1947: 12). Sanções aqui devem ser entendidas em sentido amplo, de controle do superior de influenciar efetivamente (positiva ou negativamente) o "bem-estar" do subordinado.

A relação superior-subordinado pode ser entendida pelo conceito de papel (Simon, 1947: 130-131). As pessoas, em diversas instâncias, agem de acordo com papéis prescritos, tais como o de superior e subordinado, ou seja, agem de acordo com o que é socialmente esperado delas naquela posição. O conteúdo do papel tem seu principal fundamento no costume. O grau de obediência esperado de um empregado, por exemplo, variará de acordo com a situação social. ${ }^{173}$

Simon (1947: 134) afirma que a autoridade permite a coordenação dos comportamentos individuais na organização ao fazer com que uma decisão tomada possa, ao ser comunicada, determinar outras decisões. Assim, a autoridade proporciona uma especialização da tomada de decisão no interior da organização, possibilitando uma separação entre o processo de tomada de decisão e a execução propriamente dita. Desta maneira as decisões específicas são

\footnotetext{
${ }^{173}$ Este conteúdo inclui uma expectativa de obediência e uma boa vontade em obedecer: "The willingness of the subordinate to accept a command, if given, does not imply that all, or even most, of his behavior choices are governed by commands. It is necessary to distinguish, therefore, between specific behavior which are momentary instances of the exercise of authority, and the roles played by two persons over a period of time
} 
subordinadas às mais gerais, possibilitando a integração do comportamento numa hierarquia de decisões. Conseqüência disso é que a divisão do trabalho pode abarcar a função de tomada de decisão. Outra conseqüência é, lembrando das discussões com Hayek, a pertinência e desejabilidade de algum grau de centralização nessa função. A autoridade não é o único meio para efetuar estas operações, mas, como foi dito, é um dos modos de influência. O autor (Simon, 1947: 135, 152) nota que, a despeito disso, a autoridade é amplamente utilizada como instrumento para a coordenação. Em particular, em larga medida ela é uma alternativa funcional ao treinamento, como veremos no próximo item.

Segundo Simon, a autoridade tem ao menos três importantes funções na integração do comportamento no interior de organizações: ela possibilita a atribuição de responsabilidade ao indivíduo que detém a autoridade, garante a perícia na tomada de decisões, e permite a coordenação das atividades e assim, por conseguinte, a especialização e centralização na tomada de decisões.

\subsubsection{Comunicação}

No esquema teórico de Simon, a comunicação é condição necessária para a influência interpessoal e, portanto, para a coordenação do comportamento no interior da organização. Por conseqüência, sem comunicação a organização não seria possível. Simon define comunicação como qualquer processo através do qual premissas de decisão são transmitidas de um membro para outro na organização (Simon, 1947: 154). "O que corresponde, nas ciências sociais, ao postulado 'não há ação à distância'? Acho que o análogo direto é 'não há influência sem comunicação"” (Simon, 1957: 7).

Segundo Simon, a forma como é realizada a comunicação numa organização tem papel preponderante na determinação da distribuição da função de tomada de decisão no interior da mesma. Para que um decisor tome decisões apropriadas do ponto de vista da organização, canais de informação devem existir de tal forma a lhe transmitir a informação relevante a partir de suas fontes. Além disso, uma vez tomada essa decisão, outros canais de comunicação devem existir que possam transmitir a decisão tomada para que ela exerça a influência pertinente. A complexidade da organização e a interdependência entre suas partes serão 
limitadas pela sua capacidade de comunicação (Simon, 1947: 154-156; March e Simon, 1958: $162,167)$.

Dado que, tipicamente, os pontos de execução e as fontes de informações são fixos ou pouco flexíveis, uma questão central passa ser onde situar os centros de decisão na organização. E neste ponto podemos ver com maior clareza a tensão entre os argumentos de Simon e de Hayek. Na seção anterior foi apontado que a autoridade permite que a perícia seja aplicada nas decisões, possibilita a atribuição de responsabilidade à decisão, e a incrementa a capacidade de coordenação. Estes são fatores que pedem por um aprofundamento da divisão vertical do trabalho, da especialização da função de tomada de decisão na organização. Se estes fatores pendem para o lado da centralização, fatores relativos à comunicação (nos termos de Hayek a utilização do conhecimento particular de momento e lugar) pendem para a direção oposta. O fato de que uma parcela importante da informação relevante para a decisão tem como fonte o nível operacional da organização e, além disso, o fato de que a separação entre este e os centros de decisão aumenta as dificuldades - os custos - de transmissão de informações para os últimos e de decisões para o primeiro, fazem com que os centros de decisão sejam atraídos para as fontes de informação, tendendo assim a descentralizar a estrutura decisória. A questão da alocação dos centros de decisão na organização é, portanto, encontrar um bom compromisso entre estas forças contrárias (Simon, 1947: 157). Essa questão se coloca com particular força na teoria da administração:

One of the major contemporary issues in organization design is the question of how centralized or decentralized the decision-making process will be - how much of the decision making should be done by executives of the larger units, and how much should be delegated to lower levels. But centralizing and decentralizing are not genuine alternatives for organizing. The question is not whether we shall decentralize, but how far we shall decentralize. What we seek, again, is a golden mean: we want to find the proper level in the organization hierarchy - neither too high nor too low - for each important class of decision. (Simon, 1960: 43)

Assim, se Simon não concorda com o grau de descentralização defendido por Hayek, também está longe de defender uma centralização total. Simon não nega as virtudes do sistema de preços como mecanismo de coordenação, mas a questão tem a ver com uma adequada medida entre este e outros mecanismos visando, como Hayek, o bom uso do conhecimento disponível, tanto o disperso quanto o concentrado.

Outro fenômeno interessante que ocorre nos processos de comunicação no interior de organizações é o da absorção de incerteza, que de acordo com March e Simon (1958: 165), é 
muito freqüente. Absorção de incerteza ocorre quando, a partir de um conjunto de evidências chega-se a uma conclusão, e apenas a conclusão é transmitida. A absorção da incerteza torna difícil para o receptor da informação avaliar sua validade, pois desconhece as evidências em que foi baseada e não há muito que possa fazer a não ser aceitá-la, ou rejeitá-la, tal como a recebeu. Dado que muito da absorção da incerteza ocorre próximo à fonte da informação, este fenômeno força a aproximação entre os centros de tomada de decisão e as fontes de informação. E, de qualquer maneira, qualquer que seja a posição da autoridade formal na organização, uma grande parte do poder discricionário é exercido de fato nos pontos de absorção de incerteza (March e Simon, 1958: 167). Neste contexto, a centralização da função de tomada de decisão na organização pode, portanto, ser realizada apenas na medida em que os canais de comunicação apropriados sejam desenvolvidos.

\subsubsection{Treinamento}

Do ponto de vista de Simon (1947: 169), o treinamento pode ser visto como uma forma de comunicação. Sua característica é visar a internalização das premissas de decisão por parte dos membros de organização. Treinados, estes podem tomar decisões apropriadas sem supervisão constante, e neste sentido o treinamento é uma alternativa funcional à autoridade. ${ }^{174} \mathrm{O}$ treinamento é particularmente necessário justamente quando é mais difícil realizar a supervisão e quando maior discrição é deixada ao subordinado (Simon, 1947: 170171, 225-226). No entanto, ele só é interessante na medida em que existam elementos que se repitam num grande número de decisões. O treinamento pode exercer influência em todas as classes de premissas de decisão (Simon, 1947: 16): pode prover informação, pode dar um quadro de referência para tratar de situações particulares, pode ensinar soluções préaprovadas, ou pode doutrinar o indivíduo com os valores sobre os quais deve basear a decisão. Assim, o treinamento permite um maior grau de descentralização da tomada de decisão (Simon, 1947: 170-171).

\footnotetext{
${ }^{174}$ Como explica o autor: "Like organizational loyalties and the efficiency criterion, and unlike the other modes of influence we have been discussing, training influences decision 'from inside out.' That is, training prepares the organization member to reach satisfactory decisions himself, without the need for the constant exercise of authority or advice. In this sense, training procedures are alternatives to the exercise of authority or advice as means of control over the subordinate's decisions." (Simon, 1947: 15)
} 


\subsubsection{O critério da eficiência}

O critério da eficiência tem uma trajetória curiosa na obra de Simon. Em Administrative Behavior, ele é citado como uma premissa fundamental de todo o comportamento racional, em particular ele é a premissa por excelência que trata das questões factuais numa decisão (Simon, 1947: 172, 184, 197). Além disso, esta é uma premissa internalizada e, entre as internas, é a única que não é inculcada pela participação na organização, mas é pressuposto do comportamento racional não desperdiçar recursos escassos deliberadamente ou conscientemente. No entanto, em livros publicados algum tempo depois, como Organizations (March e Simon, 1958) e Models of Man, Social and Rational (Simon, 1957), o critério da eficiência virtualmente desaparece. ${ }^{175} \mathrm{O}$ trecho abaixo ressalta a importância inicialmente atribuída ao critério para o comportamento racional:

What about the issues of fact that underlie his decisions? These are largely determined by a principle that is implied in all rational behavior: the criterion of efficiency. In the broadest sense, to be efficient simply means to take the shortest path, the cheapest means, toward the attainment of the desired goals. The efficiency criterion is completely neutral as to what goals are to be attained. (Simon, 1947: 14)

A definição formal de Simon para o critério da eficiência não foge das definições tradicionais do conceito (Simon, 1947: 122, 172-173). O critério da eficiência dita que: entre duas alternativas de mesmo custo deve ser escolhida aquela que alcançar a maior realização dos objetivos e, entre duas alternativas que atinjam igualmente os objetivos, deve ser escolhida aquela de menor custo. Alternativas com diferentes custos e graus de realização dos objetivos não podem ser comparadas pelo critério da eficiência. No entanto, na prática, como os recursos são escassos, a decisão sempre pode ser tratada como sendo uma escolha entre alternativas de mesmo custo (de oportunidade). O critério da eficiência então se reduz a escolher, para recursos dados, a alternativa que garante a maior realização dos objetivos em consideração (Simon, 1947: 180).

Minha interpretação para o desaparecimento é de que o critério da eficiência mostrou-se pouco útil do ponto de vista analítico e, ao mesmo tempo, introduzia ruído nas críticas de Simon à teoria econômica. Em primeiro lugar, o critério da eficiência é redundante com o restante da estrutura teórica de Simon - mesmo em Administrative Behavior. Quando dizemos

\footnotetext{
${ }^{175} \mathrm{Na}$ extensa introdução à terceira edição de Comportamento Administrativo (Simon, 1976a) pouca referência é feita ao capítulo IX, dedicado ao critério da eficiência.
} 
que o comportamento é adaptativo no interior de seu ambiente subjetivo de escolha, quando dizemos que o comportamento tem a intenção de racionalidade, estamos dizendo que o critério de eficiência é utilizado na escolha. Em segundo lugar, no tratamento do critério da eficiência, Simon bebia diretamente das fontes da teoria econômica, com a única ressalva de que o critério deveria ser utilizado no sentido normativo e não descritivo, o que seguramente não o ajudava a fazer a distinção entre sua própria teoria e a teoria econômica tradicional. ${ }^{176}$

\subsubsection{Programas de execução}

As rotinas de uma organização são também parte importante do ambiente organizacional no que se refere à influência da organização sobre o comportamento individual. March e Simon (1958: 139-150) adotam, para o caso limite de um comportamento completamente rotinizado, o conceito de programa de execução (performance program). $\mathrm{Na}$ definição dos autores:

We have seen that under certain circumstances the search and choice processes are very much abridged. At the limit, an environmental stimulus may evoke immediately from the organization a highly complex and organized set of responses. Such a set of responses we call a performance program, or simply a program. For example, the sounding of the alarm gong in a fire station initiates such a program. So does the appearance of a relief applicant at a social worker's desk. So does the appearance of an automobile chassis in front of the work station of a worker on the assembly line. (March e Simon, 1958: 141)

Atividades são rotinizadas, portanto, na medida em que a escolha tiver sido simplificada pelo desenvolvimento de uma resposta fixa para um estímulo definido, ou seja, na medida em que a busca tiver sido suprimida da decisão (March e Simon, 1958: 142).

Os programas de execução são característicos tanto do comportamento organizacional quanto do comportamento individual. Hábitos ou idiossincrasias pessoais podem ser incluídos neste conceito. Neste sentido, eles poderiam ser pensados como mecanismos simplificadores

\footnotetext{
${ }^{176} \mathrm{O}$ trecho abaixo deixa isso claro: "It can be seen that the criterion of efficiency as applied to administrative decisions is strictly analogous to the concept of maximization of utility in economic theory. It is not asserted here that the criterion of efficiency always does dominate administrators, decisions, but rather that if they were rational it would. There is no assertion that such rationality is a common characteristic of actual behavior. On the other hand, the doctrine of maximization of utility has been set forth in the economic literature as an explanatory doctrine as well, that is, as descriptive of actual behavior in the market. This difference between the two propositions should be kept carefully in mind. ... The broad scope of the analogy will become increasingly clear as the discussion proceeds. It will be seen that the problem of administrative decisions can be translated into a problem in the theory of production, and that concepts and theorems developed in economic theory have wide applicability to administrative decisions." (Simon, 1947: 182, ver também p. 186-190). A este respeito veja também nota 131 .
} 
da decisão, conforme foram denominados no capítulo anterior. No entanto, podemos tratar os programas de execução como caso particular da hierarquia de decisões, na medida em que uma decisão geral, que seleciona o programa, orienta outras decisões particulares: as execuções do programa. Do ponto de vista da organização, os programas de execução encontram sua especificidade no conteúdo e estrutura interconectada de diferentes programas. No caso da organização estes programas de execução são, claramente, parte importante daquilo que foi chamado acima de estrutura organizacional, mas convém manter os conceitos distintos. A estrutura organizacional é algo mais amplo que o conjunto de programas de execução que ela possui. ${ }^{177}$

Programas de execução têm um papel importante na definição de expectativas dos agentes a respeito do comportamento dos demais no interior da organização. Quanto mais programadas as atividades individuais no interior da organização, maior a sua previsibilidade. O mesmo vale do ponto de vista do comportamento da organização como um todo (March e Simon, 1958: 143). A inter-relação entre os diferentes programas de execução no interior de uma organização reforça a coordenação entre os comportamentos individuais em um padrão maior, organizacional.

\subsubsection{Identificação}

O último modo de influência organizacional que analisaremos é o importante mecanismo de identificação ou lealdade organizacional. Já tratamos dele na primeira seção deste capítulo, mas cabe discuti-lo com mais atenção. Segundo Simon, é este mecanismo que permite que os membros da organização tomem decisões como membros dela, vale dizer, que eles tomem decisões por si mesmos de acordo com os objetivos organizacionais. Nas palavras do autor:

Decisions are not made by 'organizations' but by human beings behaving as members of organizations. There is no logical necessity that a member of an organization shall make his decisions in terms of the values which are organizationally limited. Nevertheless, in

\footnotetext{
177 “Organization structure, over and above standard operating procedures, is itself a partial specification of decision-making programs. The organization structure establishes a common set of presuppositions and expectations as to which members of the organization are responsible for which classes of decisions; it establishes a structure of subgoals to serve as criteria of choice in the various parts of the organization; and it establishes intelligence responsibilities in particular organization units for scrutinizing specific parts of the organization's environment and for communicating events requiring attention to appropriate decision points." (Simon, 1960: 10).
} 
example after example, we can find individuals behaving as though the institutions to which they belong were 'economic men,' always calculating the 'institutional utility,' in terms both of service and conservation goals, in each decision. (Simon, 1947: 202)

Se as motivações pessoais determinam a participação ou não do indivíduo na organização, uma vez que ele a integra, suas decisões como membro da organização têm caráter impessoal. É o fato de suas ações terem este caráter que dá existência ao grupo, enquanto distinto do conjunto de indivíduos. ${ }^{178}$ Mais tecnicamente, um indivíduo se identifica com o grupo quando, ao tomar uma decisão, a avalia relativamente às conseqüências da ação para o grupo, isto é, em termos do sistema de valores do grupo (Simon, 1947: 205). É característica marcante do comportamento humano a tendência de membros de grupos organizados se identificarem com o grupo de que fazem parte (Simon, 1947: 12), embora essa identificação não necessariamente ocorra. Como vimos, isso está associado à docilidade.

Um novo membro da organização adquire, no interior dela, o papel de membro, uma personalidade organizacional: a identificação é gradualmente internalizada a partir da participação (Simon, 1947: 198). Assim como com relação ao exercício da autoridade a ação impessoal por parte dos indivíduos também está sujeita a uma zona de aceitação, fora dela a personalidade individual volta a impor-se (Simon, 1947: 204).

O fenômeno da identificação tem também estreita relação com os mecanismos cognitivos estudados na seção 3.2, em particular com a fatoração das decisões. A fatoração da decisão gera subojetivos, que são meios para a persecução de objetivos mais gerais. Ao identificar-se com um subobjetivo particular da organização, o membro da organização associa-se a um elo da cadeia de meios e fins correspondente a uma subunidade da organização. Simon (1947: 13) afirma que isso, por um lado, faz com que a racionalidade na administração seja possível, na medida em que dispensa o administrador de avaliar cada decisão de acordo com os valores finais da organização - ou, do ponto de vista da sociedade, de acordo com "toda a escala de valores humanos" - e permite que ele dê atenção a um objetivo de escopo limitado. Segundo ele:

\footnotetext{
178 Simon empresta a idéia de impessoalidade do comportamento na organização de Chester Barnard: "The system, then, to which we give the name 'organization' is a system composed of the activities of human beings. What makes these activities a system is that the efforts of different persons are not personal. They are determined by the system either as to manner, or degree, or time. Most of the efforts in cooperative systems are easily seen to be impersonal. ... Hence, when we say that we are concerned with a system of coordinated human efforts, we mean that although persons are agents of the action, the action is not personal in the aspect important for the study of cooperative systems." (Chester Barnard apud Simon, 1947: 203)
} 
...[I]dentification is an important mechanism for constructing the environment of decision. When identification is faulty, the resulting discrepancies between social and organizational values result in a loss of social efficiency. When the organizational structure is well conceived, on the other hand, the process of identification permits the broad organizational arrangements to govern the decisions of the persons who participate in the structure. Thereby, it permits human rationality to transcend the limitations imposed upon it by the narrow span of attention. (Simon, 1947: 210-211)

Por outro lado, a identificação com subojetivos também faz com que sejam desconsiderados efeitos indiretos - positivos ou negativos, do ponto de vista dos objetivos mais gerais da organização - caso estes existam. Isso ocorre justamente porque a atenção do administrador está focada nos subobjetivos (March e Simon, 1958: 152). ${ }^{179}$ Assim, a formação de subojetivos também possui seus contras:

Since it is difficult to establish subsidiary objectives that will always be consistent with the general objective, the individual who is a member of the subsidiary organization will sometimes make decisions that are consistent with the partial objective of his particular organizational component, but inconsistent with the broader goal of the organization as a whole. (Simon, 1947: 201)

Diante disso, aponta Simon (1947: 214), se coloca o problema de saber como distribuir as funções no interior da organização de tal forma que as identificações contribuam para a tomada de decisão apropriada. ${ }^{180}$ Além disso, Simon nota que, como a grande maioria das decisões não é tomada tendo em vista valores finais, em geral a identificação se dá em relação a subojetivos. A cognição também afeta a formação destes subobjetivos de maneira importante. O processo de formação de objetivos depende das relações percebidas entre meios e fins pois, como raramente as decisões são tomadas relativamente a valores finais, $o$ (sub)objetivo escolhido depende de crenças a respeito de que meios são adequados para a persecução de determinados fins (March e Simon, 1958: 151).

A identificação organizacional, como discutido acima, é melhor entendida como uma forma de altruísmo, pois a escala de valores pessoais é substituída pela impessoal, pelos

\footnotetext{
${ }^{179}$ March e Simon (1958: 65) apontam quatro alvos principais para identificação: outras organizações que não a organização em questão, a organização propriamente dita, unidades internas à organização, e a tarefa executada. Este problema se manifesta relativamente aos dois últimos.

${ }^{180}$ A subdivisão "natural" da organização reaparece aqui pois o autor ressalta que existem condições para o sucesso desta empreitada, que são as seguintes: "The way in which activities are subdivided in the organization will have a major influence on identification. The administrative segregation of a function will be satisfactory to the extent that (1) the activities involved in the performance of the function are independent of the other activities in the organization, (2) indirect effects of the activity, not measurable in terms of the functional objective, are absent, and, (3) it is possible to set up lines of communication which will bring to the unit
} 
objetivos organizacionais. Esta é, portanto, uma importante forma de influência organizacional que permite a cooperação, o compartilhamento dos mesmos objetivos, entre os membros da organização.

Assim, a organização possui uma série de poderosos modos de influência que permitem a concatenação do comportamento de seus membros, formando um padrão de comportamento da organização que vai além de uma coleção de comportamentos individuais.

\subsection{Organizações}

Neste capítulo discutimos o papel que tem o conceito de organização na teoria comportamental de Simon. Vimos a flexibilidade do uso que o autor faz do conceito e também a importância por ele atribuída à organização no que diz respeito ao comportamento econômico em particular.

A organização aparece como contexto comportamental predominante na obra econômica de Simon. Como vimos no capítulo anterior, as restrições à racionalidade minam as pretensões generalistas da teoria econômica neoclássica e tornam o comportamento fortemente dependente do contexto, localizado. O estudo das organizações pode ser visto como preenchendo esta lacuna, mas historicamente a relação é inversa. Simon foi sensibilizado às restrições à racionalidade a partir da observação do comportamento em organizações.

Passamos em revista diversos modos de influência organizacional sobre $\mathrm{o}$ comportamento individual. Particularmente importantes entre eles são aqueles que fundamentam a impessoalidade do comportamento no interior da organização - a identificação organizacional e a autoridade -, permitindo pensar que os participantes da organização tomem decisões como membros dela, e não necessariamente de acordo com seus objetivos pessoais. A autoridade organizacional é resultante de uma decisão de participação do indivíduo, em especial a relação empregatícia, compatibilizando assim os objetivos organizacionais com os pessoais. Supor que os membros da organização se identificam com 
ela implica supor que os indivíduos podem exibir comportamento altruísta, hipótese fortemente questionada pela teoria econômica e teoria evolucionária recentes. Simon fundamenta o comportamento altruísta, e portanto a identificação organizacional, numa base cognitiva e evolucionária, através do conceito de docilidade.

Uma percepção do papel central que cumprem as grandes organizações nas economias hodiernas e a fundamentação destes mecanismos de influência organizacional levam Simon, por sua vez, a questionar a predominância do conceito de mercado sobre o de organização na teoria econômica. Em particular, o autor argumenta que a identificação organizacional e a autoridade são importantes mecanismos de coordenação do comportamento e que são tão ou mais importantes nesta função quanto o sistema de preços. Simon então desloca o debate clássico sobre a descentralização das decisões da velha oposição entre planejamento central vs laissez faire para uma indagação acerca da adequada medida da centralização das decisões na economia. E assim ele sustenta o papel das organizações na economia como meios eficientes de coordenação e de alocação de recursos. 


\section{Considerações Finais}

Propus-me neste estudo a fazer uma apresentação dos aspectos da obra de Herbert Simon que julguei, em boa medida porque ele mesmo julgava, mais importantes para a economia. Estes aspectos resultaram girar em torno de sua teoria comportamental. Esta teoria por sua vez foi aqui dividida em dois temas: o da racionalidade e o da organização. Estes temas são duas partes essenciais da teoria e devem caminhar sempre juntos no sentido de que, respectivamente, tratam da estrutura da teoria e do contexto ao qual ela se aplica. $\mathrm{O}$ fato de Simon teorizar a organização e, portanto, tratá-la também com estrutura não deve desviar o leitor da idéia de que a organização fornece, antes de tudo, o ambiente - o contexto, suas particularidades, suas especificidades - no qual o agente racional atua. Esta ênfase na relevância do ambiente e da conjuntura, por si só, representa um tour de force de Simon contra o húbris generalizante da teoria neoclássica e demanda dos economistas uma aproximação da empiria e do detalhe, como diria o próprio, "das deselegâncias do mundo real".

No processo de realização deste estudo também se concretizou, de maneira algo independente, uma incursão no contexto histórico em que Simon realizou seu trabalho. Não que algum contexto não fosse necessário, mas a forma e dimensão que veio a tomar constituem, do ponto de vista do objetivo proposto, praticamente um enxerto no estudo. Esta história girou em torno de Simon e da pesquisa operacional, e do papel que esta última cumpriu na reconfiguração das ciências sociais, e da economia em particular, nos EUA ao longo da segunda metade do século XX.

Ao final de um trabalho de compilação como este poderia ser esperada uma avaliação da obra do autor, uma posição minha a respeito dela. Mas não pretendo atender a esta expectativa, ao menos não de maneira explícita. O principal motivo é que eu mesmo, ao final deste estudo, tenho os sentimentos algo ambíguos com relação a Simon. Não sinto, por outro lado, nenhuma urgência de resolver esta ambigüidade, nem pessoalmente e nem o que dela transparece, suponho, no próprio trabalho. Não resolvê-la permite ainda que o leitor exerça seu próprio julgamento. Não sei se cabe também, a esta altura, repassarmos os tópicos que discutimos ao longo do trabalho. Ao menos no que diz respeito à apresentação da obra de 
Simon, o resultado já é em si um grande resumo e não acho que convenha condensá-lo numa pílula. Sugiro então, como encerramento deste estudo, não no sentido de fechá-lo mas no contrário, fazer curtas explorações, a partir do que foi apresentado, de dois temas. São temas relativamente amplos, mas que se sugerem fortemente no trabalho de Simon e que, espero, estimulem pensar sobre ele.

\subsection{Racionalidades}

Há três imagens do comportamento racional - ou, vale dizer, da racionalidade - que aparecem na obra de Simon: a lógica, o labirinto e a adaptabilidade. Esta seqüência caminha numa ordem de redução de estatuto do conceito mas, ao mesmo tempo, de aumento de generalidade. Elas não são também mutuamente excludentes e, em geral, podem ser encontradas misturadas. A idéia aqui é jogar um pouco com a concepção, as concepções na verdade, que Simon tem de 'racionalidade'.

A racionalidade como lógica é a primeira que cruza a vista de Simon. Diante da impossibilidade (lógica) de qualquer comportamento racional ignorar a lógica, a racionalidade é equalizada a ela. A metáfora propriamente dita é o pensamento como a dedução a partir de premissas. Racionalidade é cálculo, é computação, é apenas e tão somente uma seqüência de operações (tauto)lógicas a partir de premissas dadas. Esta é uma concepção bastante comum da racionalidade, mas acho apropriado afirmar que ele a encontra na teoria econômica neoclássica. Seria incorreto inferir da crítica de Simon à teoria neoclássica que ele não faz uso também desta concepção. O que ele critica é a associação da onisciência a ela. A própria idéia de tomada de decisão, em Simon e alhures, está fortemente ligada à lógica uma vez que, em geral, se associa a um ambiente de decisão minimamente fechado e estável.

A adaptabilidade é uma concepção bem mais fraca da racionalidade. Em particular, parece difícil sustentar qualquer singularidade humana associada a ela. A adaptabilidade é introduzida na teoria cognitiva de Simon através da "análise de meios e fins", que foi incorporada no programa batizado de General Problem Solver. A análise de meios e fins consiste basicamente em comparar o objetivo com a situação e encontrar diferenças entre eles, buscar alguma ação que possa reduzir esta diferença, tomar a ação e voltar a comparar 
objetivo e a nova situação, e assim sucessivamente. ${ }^{181}$ Aqui entram as idéias do procedimento e de algoritmo, especificando esta "alguma ação". Há duas fontes potenciais para esta concepção de Simon: a psicologia e a cibernética. Talvez a primeira seja de fato a origem mais provável, no entanto as semelhanças com a cibernética são grandes e cabe olharmos mais de perto.

Um dispositivo que fornece um ótimo e simples exemplo da análise de meios e fins é um termostato, seu mecanismo de funcionamento é tal qual este que acabamos de descrever. Dispositivos como o termostato são conhecidos como servomecanismos e sua principal característica é a presença de um feedback do ambiente. ${ }^{182} \mathrm{O}$ segundo elemento que compõe a modelagem cibernética, além do feedback, é a capacidade de aprendizagem - lembrem-se do "Previsor Anti-Aeronave" de Wiener descrito no segundo capítulo. Do nosso ponto de vista, o importante aqui é ressaltar a afinidade entre os processos de busca postulados por Simon e a aprendizagem. No geral, o resultado da busca pode ser interpretado como um aprendizado. Dito isto, é interessante olharmos para uma classificação do comportamento feita por Rosenblueth, Wiener e Bigelow num texto seminal da cibernética:

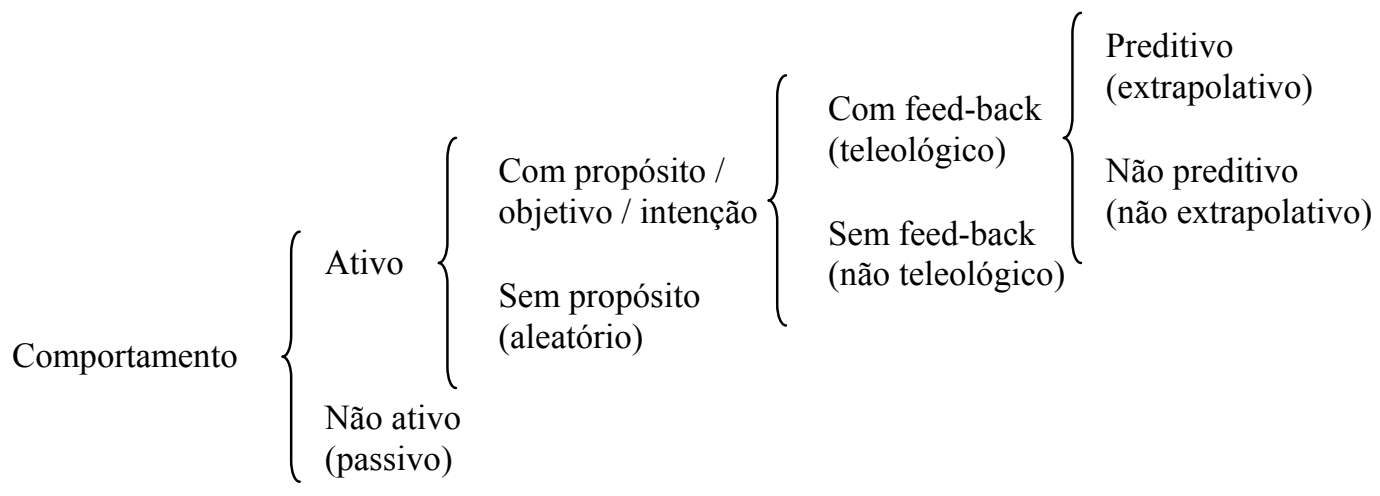

Figura 1: Classificação do comportamento (adaptada) de Rosenblueth, Wiener e Bigelow (1943).

\footnotetext{
${ }^{181}$ Claro que a concepção lógica também implica uma relação entre meios e fins deste tipo, mas ela envolve escolher $a$ ação que elimina esta diferença entre objetivo e situação. Neste sentido a concepção lógica torna-se caso particular da outra. É interessante notar que, na concepção adaptativa, no limite, a seleção da ação pode ser até mesmo aleatória, como no caso do "lendário" homeostato do ciberneticista inglês Ross Ashby (Pickering, 2002: 415-420).

${ }^{182}$ É curioso reler a descrição feita por Hayek da "maravilha do mecanismo de preços", da "sua verdadeira função", na nota 159, à luz desta distinção entre as concepções de racionalidade.
} 
Não há referência aí à racionalidade, o conceito central é o de propósito. Trata-se de uma classificação do comportamento em geral, até por isso a cibernética viria a vestir-se de uma Teoria de Tudo. Diante desta classificação, a justificativa de Simon para teorizar o comportamento como racional - nomeadamente, que o comportamento tipicamente tem a "intenção de racionalidade" - pode ser olhada sob nova luz, sob a qual a palavra intenção aparece com maior relevo.

Há um par de importantes artigos de Simon que podem ser interpretados a partir desta distinção, o "A behavioral model of rational choice" (1955a) e o "Rational choice and the structure of the environment" (1956a). ${ }^{183}$ Eles foram escritos como artigos complementares. O primeiro pode ser lido como tentando responder à pergunta: Qual é o máximo que é possível manter do modelo lógico de racionalidade e ainda dar uma descrição realista do comportamento? E o segundo à: Qual é o mínimo de estrutura necessário para dar conta de comportamentos que são usualmente tidos como racionais? No primeiro ele faz uma série de simplificações a partir dos conceitos "clássicos" de racionalidade. No segundo ele descreve o comportamento de um organismo que está mais próximo de um rato que de um ser humano (Simon, 1956a: 262). Este movimento dos extremos para o centro caracteriza bem a tentativa de mediação de Simon entre a economia e a psicologia, o que nos traz à terceira imagem, o labirinto:

"Is thinking best viewed as a process of reasoning from the premises, using the metaphor of logic, or as a process of selective search through a maze? ... The maze, of course, has been the metaphor of my own research." (Simon, 1996a: 331, veja também p. 86)

A descrição que Simon dá da imagem que tem do labirinto é uma de "escolhas sucessivas ao longo de um caminho que se bifurca”. Há mais de uma interpretação possível para esta metáfora, mas, do ponto de vista da nossa discussão é interessante pensá-la como uma mistura entre as concepções lógica e adaptativa da racionalidade, a lógica se aplicando localmente - tanto espacial, quanto temporal, quanto causalmente - nas bifurcações e a

\footnotetext{
${ }^{183}$ O próprio Simon atesta a importância deles: "If I were asked to select just two of my publications in economics for transmission to another galaxy where intelligent life had jus been discovered, these are the two I would choose." (1982b: 204); "I regard Chapters 14 [Simon, 1955a] and 15 [Simon, 1956a] as the central core of the theory of choice I am advancing here." (1957:204). O primeiro (1955a) é também o artigo de Simon citado com maior freqüência por economistas que querem se referir a seu trabalho sobre racionalidade restrita e satisfazimento (Simon, 1996a: 165).
} 
adaptabilidade se aplicando globalmente. Esta interpretação faz o labirinto se parecer com o mosaico, tal como discutido no terceiro capítulo.

Estas três concepções de racionalidade podem ser encontradas ao longo da obra de Simon. Indiquei acima alguns lugares privilegiados para encontrar algumas manifestações mais claras de cada uma delas. O próprio "Rational choice and the structure of the environment" usa, mais explicitamente que a da adaptabilidade inclusive, a idéia do labirinto. Uma leitura atenta dele deve mostrar a proximidade entre ambas as concepções. ${ }^{184} \mathrm{De}$ qualquer maneira, na prática, Simon desloca a racionalidade do âmbito da lógica, abrindo espaço para arbitrariedades. E o conteúdo arbitrário é preenchido pelo contexto.

\subsection{Economia e história}

A obra de Simon carrega implicações para a relação entre a economia e a história. Há alguns nexos entre ambas que podem ser traçados a partir da teoria comportamental de Simon. Em primeiro lugar, a partir da teoria comportamental de Simon é possível falar de mudança no sistema econômico sem corar, ao contrário do que a teoria neoclássica permite. A ortodoxia oferece modelos de crescimento, onde a idéia de mudança parece não ir além de "mais do mesmo". Desde Schumpeter, pelo menos, a transformação do sistema econômico, seu desenvolvimento, esteve fortemente associada à idéia de inovação, ${ }^{185}$ mas mesmo ele não foi adiante de postular um agente inovador para introduzir a possibilidade de mudança no sistema. O motivo desta dificuldade é que toda a análise do sistema econômico, na teoria neoclássica, é feita no interior de um sistema fechado: todas as alternativas e possibilidades são dadas de antemão. A adição da hipótese de maximização faz ainda com que, teoricamente, a economia opere em torno de um estado de equilíbrio objetivamente definido.

Simon não apenas dá espaço para a inovação, mas permite tratá-la teoricamente. $\mathrm{Na}$ medida em que o agente não parte de um conjunto fixo de alternativas ele precisa procurá-las

\footnotetext{
${ }^{184}$ Simon dedica também um capítulo de sua biografia aos labirintos, onde relata uma conversa que teve com Jorge Luis Borges sobre o assunto e reproduz um conto de sua própria autoria onde tratava do modelo de Simon (1956a) "despido dos envoltórios matemáticos": "I was so pleased with the paper's account of rationality that a year later I found myself writing a short story, 'The Apple,' fashioned after it." (1996a: 175)

${ }^{185}$ Ao menos no que diz respeito a economias capitalistas maduras. As chamadas teorias do desenvolvimento econômico, estas criadas para tratar das economias subdesenvolvidas, já tinham amplo espaço para outros conceitos.
} 
ou até mesmo idealizá-las, desenhá-las, projetá-las. Um misto de atividade de resolução de problemas e acaso dá conta da inovação sem dificuldades. Como sabemos a busca e o satisfazimento são centrais neste processo. A teoria de Simon trabalha num ambiente (subjetivamente) aberto. Daí a importância atribuída por ele às decisões estratégicas das firmas. Produtos, procedimentos de produção e de marketing, política de preços, estrutura organizacional, estratégia de longo-prazo, são todos projetados. Numa versão evolucionária do argumento, a adaptatividade não se dá apenas pela competição por nichos existentes mas também, e de maneira importante, pela elaboração de nichos. É nesse sentido que podemos falar, como Silveira, que na teoria comportamental de Simon "o construto do Homem Administrativo é compativel com abordagens históricas e evolucionárias" (1994: 59, ênfase minha; veja também 1996: 122).

Um segundo ponto, relacionado a este, é o que fazer da idéia de longo prazo. Na teoria econômica, na neoclássica em particular, "no longo prazo" parece ser uma abreviação de "em equilíbrio de longo prazo", que por sua vez parece ser uma forma mais longa de "em equilíbrio". O longo prazo é um tempo abstrato: é o tempo necessário, ceteris paribus, para a economia atingir o estado de equilíbrio. $\mathrm{O}$ argumento das restrições à racionalidade sugere outra abordagem: o longo prazo poderia ser definido, por exemplo, como o maior horizonte de tempo levado em consideração, na prática, em decisões estratégicas empresariais ou governamentais. De qualquer maneira, trata-se de um tempo concreto e certamente finito. Deste ponto de vista, o longo prazo (abstrato) ao invés de ser pensado como um destino inescapável deveria ser tratado como uma sucessão de prazos mais curtos. O elo entre estes dois primeiros pontos está no fato de que a teoria de Simon implica que a evolução de um determinado sistema econômico no tempo é bastante dependente da trajetória, de sua história portanto.

Um terceiro, e último ponto no que diz respeito ao papel da história na economia, é a grande dependência que o comportamento tem, na teoria de Simon, do contexto - seja ele o contexto organizacional, social ou histórico. É esta dependência que o leva a afirmar que a economia é "inevitavelmente localizada cultural e historicamente" (1976b: 146). Ou, em versão mais incisiva, que "a economia é, por necessidade, uma ciência histórica" (2001: 503). A posição organizacional é fator crucial para a tomada de decisão. $\mathrm{O}$ diretor de vendas toma decisões diferentes das do diretor de operações da mesma firma. A localização social explica, na teoria de Simon, a diferença entre o xadrez jogado por Bill Chase, um jogador profissional, 
e um amador. O jogador profissional, o expert, possui uma vasta quantidade de informação sobre como jogar xadrez e de procedimentos de decisão acumulados na memória aos quais o novato não tem acesso. A situação histórica dá conta da diferença entre o xadrez jogado por Paul Morphy, em 1861, e o jogado por Bobby Fisher, em 1972, grandes mestres de suas respectivas épocas. Estas mesmas considerações valem para empresários, administradores, consumidores e tantos quanto queiramos. Em outras palavras, "as leis da economia mudam com a acumulação do conhecimento humano" (Simon, 2001: 503). Diferentes países, de diferentes culturas, também terão, portanto, diferentes economias. Nestas considerações, claramente, há um grande ceticismo com relação às pretensões universalistas da teoria neoclássica. Mas, por outro lado, exigem dos economistas um trabalho empírico extensivo a respeito das práticas efetivas dos agentes econômicos. $\mathrm{Na}$ maior parte das vezes, "não podemos entender o comportamento econômico sem uma teoria correta do processo e do conhecimento efetivamente usados pelos atores ao fazer suas escolhas" (Simon, 1997a: 19), o que envolve "conhecimento empírico concreto sobre como as decisões humanas são realmente tomadas" (Simon, 1997b: xii). Simon reclama dos economistas, portanto, que matizem suas generalizações com um conhecimento histórico mais apurado. 


\section{Referências}

\section{Trabalhos de Herbert A. Simon}

Ando, Fisher e Simon 1963. Albert Ando; Franklin Fisher; e Herbert A. Simon, Essays on the structure of social science models, Cambridge, MA: The MIT Press.

Hawkins e Simon 1949. David Hawkins; e Herbert A. Simon, "Note: Some conditions of macroeconomic stability", Econometrica, 17, pp. 245-248.

Holt, Modigliani, Muth e Simon 1960. Charles C. Holt; Franco Modigliani; John F. Muth; e Herbert A. Simon, Planning production, inventories, and work force, Englewood Cliffs: Prentice-Hall.

March e Simon 1958. James G. March; e Herbert A. Simon, Organizations, New York: John Wiley and Sons.

Newell e Simon 1972. Allen Newell; e Herbert A. Simon, Human problem solving, Englewood Cliffs, NJ: Prentice-Hall.

Simon 1947. Herbert A. Simon, Administrative behavior: A study of decision-making processes in administrative organization, $1^{\text {st }}$ ed., New York: The Macmillan Company.

Simon 1952. Herbert A. Simon, "On the definition of the causal relation", Journal of Philosophy, vol. 49, July 31, pp. 517-528, reimpresso in Simon (1957, pp. 50-61).

Simon 1953a. Herbert A. Simon, "Causal ordering and identifiability" in W.C. Hood; e J.C. Koopmas (eds.). Studies in econometric method, New York: Wiley, reimpresso in Simon (1957, pp. 10-36).

Simon 1953b. Herbert A. Simon, "Notes on the observation and measurement of political power", Journal of Politics, vol. 15, November, pp. 500-516, reimpresso in Simon (1957, pp. 62-78). 
Simon 1954a. Herbert A. Simon, "Spurious correlation: a causal interpretation", Journal of the American Statistical Association, vol. 49, September, pp. 467-479, reimpresso in Simon (1957, pp. 37-49).

Simon 1954b. Herbert A. Simon, "Some strategic considerations in the construction of social science models", in Paul Lazarsfeld (ed.), Mathematical thinking in the social sciences, chap. 8, Glencoe, IL: The Free Press.

Simon 1955a. Herbert A. Simon, "A behavioral model of rational choice”, The Quarterly Journal of Economics, vol. 69, n. 1, February, pp. 99-118, reimpresso in Simon (1957, pp. 241-260).

Simon 1955b. Herbert A. Simon, "On a class of skew distribution functions”, Biometrika, vol. 42, pp. 425-440, reimpresso in Simon (1957, pp. 145-164).

Simon 1956a. Herbert A. Simon, "Rational choice and the structure of the environment", Psychological Review, vol. 63, March, reimpresso in Simon (1957, pp. 261-273).

Simon 1956b. Herbert A. Simon, "Dynamic programming under uncertainty with a quadratic criterion function", Econometrica, vol. 24, pp. 74-81.

Simon 1957. Herbert A. Simon, Models of man, social and rational: Mathematical essays on rational human behavior in a social setting, New York: John Wiley and Sons.

Simon 1960. Herbert A. Simon, The new science of management decision, New York: Harper \& Brothers.

Simon 1963. Herbert A. Simon, "Economics and psychology", in S. Koch (ed.), Psychology: The study of a science, vol. 6, New York, NY: McGraw-Hill, pp. 685-723.

Simon 1964. Herbert A. Simon, "Rationality", in J. Gould; e W.L. Kolb (eds.), A dictionary of the social sciences, Glencoe, IL: The Free Press, pp. 573-574, reimpresso in Simon (1982b, pp. 405-407). 
Simon 1968. Herbert A. Simon, "On judging the plausibility of theories", in B. van Rootselaar; e J.F. Staal (eds.), Logic, methodology and philosophy of sciences III, Amsterdam: North-Holland, pp. 439-459, reimpresso in Simon (1977, pp. 25-43).

Simon 1972. Herbert A. Simon, "Theories of bounded rationality" in: C.B. McGuire; e Roy Radner (eds.). Decision and organizations: A volume in honor of Jacob Marchak, Amsterdam: North-Holland, chap. 8, pp. 161-176.

Simon 1976a. Herbert A. Simon, Administrative behavior: A study of decision-making processes in administrative organization, $3^{\text {rd }}$ ed., ampliada, New York: The Free Press.

Simon 1976b. Herbert A. Simon, "From substantive to procedural rationality", in Spiro J. Latsis, Method and appraisal in economics, Cambridge: Cambridge University Press, pp. 129-148.

Simon 1977. Herbert A. Simon, Models of discovery: And other topics in the methods of science, Dordrecht, Holland: D. Reidel Publishing Company.

Simon 1978a. Herbert A. Simon, "Rationality as process and as product of thought", [Richard T. Ely lecture], American Economic Review, 68(2), pp. 1-16.

Simon 1978b. Herbert A. Simon, “Autobiography”, disponível em: <http://www.nobel.se/ economics/laureates/1978/simon-autobio.html>, acessado em: 06/11/2002.

Simon 1978c. Herbert A. Simon, "On how to decide what to do", The Bell Journal of Economics, 9, pp. 494-507, reimpresso in Simon (1982b, pp. 460-473).

Simon 1979a. Herbert A. Simon, "Rational decision making in business organizations" [Nobel Memorial Lecture], American Economic Review, 69(4), September, pp. 493-513.

Simon 1979b. Herbert A. Simon, "On parsimonious explanations of production relations", The Scandinavian Journal of Economics, 81, pp. 459-474, reimpresso in Simon (1982a).

Simon 1979c. Herbert A. Simon, Models of thought, vol. I, New Haven, CT: Yale University Press. 
Simon 1982a. Herbert A. Simon, Models of bounded rationality, vol. 1, Cambridge, MA: The MIT Press.

Simon 1982b. Herbert A. Simon, Models of bounded rationality, vol. 2, Cambridge, MA: The MIT Press.

Simon 1983. Herbert A. Simon, Reason in human affairs, Stanford, CA: Stanford University Press.

Simon 1986. Herbert A. Simon, "Rationality in psychology and economics", The Journal of Business, 59(4), pt. 2, S209-S224, 1986, reimpresso in Robin M. Hogarth; e Melvin W. Reder (eds.), Rational choice: The contrast between economics and psychology, Chicago and London: The University of Chicago Press, 1987.

Simon 1987. Herbert A. Simon, "Satisficing", in John Eatwell; Murray Milgate; e Peter Newman (eds.), The new Palgrave: A dictionary of economics, vol. 4, New York: Palgrave, pp. 243-245.

Simon 1989. Herbert A. Simon, Models of thought, vol. II, New Haven, CT: Yale University Press.

Simon 1991. Herbert A. Simon, "Organizations and markets", The journal of economic perspectives, vol. 5, n. 2 (Spring), pp. 25-44.

Simon 1996a. Herbert A. Simon, Models of my life, Cambridge, MA: The MIT Press, 1996, originalmente publicado: New York: Basic Books, 1991.

Simon 1996b. Herbert A. Simon, The sciences of the artificial, $3^{\text {rd }}$ ed., Cambridge, MA: The MIT Press.

Simon 1997a. Herbert A. Simon, An empirically based microeconomics, Cambridge, UK: Cambridge University Press.

Simon 1997b. Herbert A. Simon, Models of bounded rationality, vol. 3, Cambridge, MA: The MIT Press. 
Simon 2001. Herbert A. Simon, "Discussion: On simulating Simon: His monomania, and its sources in bounded rationality", Studies in History and Philosophy of Science, 32 (3), pp. 501-505.

Simon e Ando 1961. Herbert A. Simon; e Albert Ando, “Aggregation of variables in dynamic systems", Econometrica, 29, pp. 111-138.

Simon e Levy 1963. Herbert A. Simon; e Ferdinand K. Levy, "A note on the Cobb-Douglas function", The Review of Economic Studies, 30, pp. 93-94, reimpresso in Simon (1982a).

\section{Trabalhos de outros autores}

Ando 1979. Albert Ando, "On the contributions of Herbert A. Simon to economics", The Scandinavian Journal of Economics, 81(1), pp. 83-93.

Augier 2001. Mie Augier, "Sublime Simon: the consistent vision of economic psychology's Nobel laureate", Journal of Economic Psychology, 22, pp. 307-334.

Baumol 1979. William J. Baumol, "On the contributions of Herbert A. Simon to economics", The Scandinavian Journal of Economics, 81(1), pp. 74-82.

Berelson 1963. Bernard Berelson (ed.), The behavioral sciences today, New York, London: Basic Books.

Bergmann 1967. Gustav Bergmann, "Logical positivism", in The metaphysics of logical positivism, $2^{\text {nd }}$ ed., Madison, Milwakee, London: The University of Wisconsin Press, (primeira edição de 1954).

Blaug 1980. Mark Blaug, "The distinction between positive and normative economics", in The methodology of economics: Or how economists explain, Cambridge: Cambridge University Press.

Bowker 1993. Geof Bowker, "How to be universal: Some cybernetic strategies, 1943-1970", Social Studies of Science, vol. 23, n. 1, Feb. 1993, pp. 107-127. 
Conlisk 1996. John Conlisk, "Why bounded rationality?", Journal of Economic Literature, vol. 34, n. 2, Jun., pp. 669-700.

Dennis 2002. Michael Aaron Dennis, "Big Science", Enciclopaedia Britannica, Deluxe Edition CD-ROM.

Foley 2003. Duncan K. Foley, Rationality and ideology in economics, talk for Anwar Shaikh's New School Graduate Faculty class World Political Economy, March 18.

Fortun e Schweber 1993. Mike Fortun; e S. S. Schweber, "Scientists and the legacy of World War II: The case of operations research (OR)", Social Studies of Science, vol. 23, n. 4, Nov., pp. 595-642.

Friedman 1953. Milton Friedman, "The methodology of positive economics", in Essays in positive economics, The University of Chicago Press.

Galison 1992. Peter Galison, "Introduction: The many faces of Big Science", in Peter Galison; e Bruce Hevly (eds.). Big Science: The growth of large-scale research, Stanford: Stanford University Press.

Hands e Mirowski 1998a. D. Wade Hands; e Philip Mirowski, "Harold Hotelling and the neoclassical dream", in Roger E. Backhouse; Daniel M. Hausman; Uskali Mäki; e Andrea Salanti (eds.), Economics and methodology: Crossing boundaries, London: Macmillan, pp. 322-397.

Hands e Mirowski 1998b. D. Wade Hands; e Philip Mirowski, “A paradox of budgets: The postwar stabilization of american neoclassical demand theory", in Mary S. Morgan; e Malcom Rutherford (eds.), The transformation of american economics: From interwar pluralism to postwar neoclassicism, Durham, NC: Duke University Press, pp. 260-292.

Hayek 1945. Friedrich A. Hayek, "The use of knowledge in society", American Economic Review, vol. 35, n. 4, September, pp. 519-530.

Horowitz 1969. Irving Louis Horowitz (org.), Ascensão e queda do Projeto Camelot: Estudos sobre as relações entre ciência social e a prática política, Rio de Janeiro: Civilização Brasileira. 
Klaes e Sent 2002. Mathias Klaes; e Esther-Mirjam Sent, An institutional history of the emergence of the concept of bounded rationality, paper presented at the Biennial Conference at INEM and the Annual Conference of the UK HET Group, Stirling, September.

Knudsen 1993. Christian Knudsen, "Equilibrium, perfect rationality and the problem of selfreference in economics", in Uskali Mäki; Bo Gustafsson; e Christian Knudsen, Rationality, institutions and economic methodology, London: Routledge.

Kuper 2002. Adam Kuper, "Clifford Geertz: Cultura como religião e como grande ópera", in Cultura: A visão dos antropólogos, Bauru: EDUSC, pp. 105-159.

Lerner e Lasswell 1951. Daniel Lerner; and Harold D. Lasswell (eds.), The policy sciences: Recent developments in scope and method, Stanford, CA: Stanford University Press.

Mirowski 1999. Philip Mirowski, “Cyborg agonistes: Economics meets operations research in mid-century", Social Studies of Science, vol. 29, n. 5, Oct., pp. 685-718.

Mirowski e Sent 2002. Philip Mirowski; e Esther-Mirjam Sent (eds.), Science bought and sold: Essays in the economics of science, Chicago and London: The University of Chicago Press, 2002.

Mills 1959. Charles Wright Mills, The sociological imagination, New York: Oxford University Press.

Muth 1961. John F. Muth, "Rational expectations and the theory of price movements", Econometrica, vol. 29, n. 3, July, pp. 315-335.

Nisbet 1962. Robert A. Nisbet, “A sociologia como uma forma de arte”, Plural: Revista do curso de pós-graduação em sociologia da USP, São Paulo, $\mathrm{n}^{\circ} 7,1^{\circ}$ semestre de 2000, pp. 111-130, originalmente publicado: Pacific Sociological Review, Fall 1962, 67-74.

Pickering 1995a. Andrew Pickering, "Cyborg history and the World War II regime", Perspectives on Science, vol. 3, n. 1, pp. 1-48. 
Pickering 1995b. Andrew Pickering, Science, technology and the World War II regime, text of seminar presented September 1995, mimeo, <http://www2.uiuc.edu/unit/STIM/ WW2R.html>, acessado em 02/06/04.

Pickering 2002. Andrew Pickering, "Cybernetics and the mangle: Ashby, Beer and Pask", Social Studies of Science, vol. 32, n. 3, June, pp. 413-437.

Pollack 1986. Michael Pollack, "Paul F. Lazarsfeld, fundador de una multinacional científica”, in Fernando Alvarez-Uría; e Julia Varela (orgs.), Materiales de sociologia critica, Madrid: La Piqueta, pp. 37-82.

Rosenblueth, Wiener e Bigelow 1943. Arturo Rosenblueth; Norbert Wiener; e Julian Bigelow, “Behavior, purpose and teleology”, Philosophy of science, vol. 10, n. 1, Jan., pp. 18-24.

Scand. J. Economics 1979. "The Nobel Memorial Prize in Economics 1978: Bibliography”, The Scandinavian Journal of Economics, 81(1), pp. 94-114.

Sent 1997. Esther-Mirjam Sent, "Sargent versus Simon: bounded rationality unbound", Cambridge Journal of Economics, 21, pp. 323-338.

Sent 1998. Esther-Mirjam Sent, "Herbert A. Simon", in John B. Davis; D. Wade Hands; e Uskali Mäki (eds.), The Handbook of Economic Methodology, Cheltenham: Edward Elgar, pp. 457-458.

Sent 1999. Esther-Mirjam Sent, "Administrative Man versus/as Economic Man: Review of 'Administrative Behavior, 4th edition' by Herbert A. Simon," Journal of Economic Methodology, 6 (1), pp. 133-139.

Sent 2000. Esther-Mirjam Sent, "Herbert A. Simon as a cyborg scientist", Perspectives on Science, vol. 8, n. 1, pp. 380-406.

Sent 2001a. Esther-Mirjam Sent, "Sent simulating Simon simulating scientists", Studies in History and Philosophy of Science, 32 (3), pp. 479-500.

Sent 2001b. Esther-Mirjam Sent, "Obituary: Herbert A. Simon (1916-2001)", European Association for Evolutionary Political Economy Newsletter, 26 (July), pp. 1-2. 
Silveira 1983. Antonio Maria da Silveira, "Simon e o satisfazimento", Literatura Econômica, 5(5), Rio de Janeiro: IPEA, setembro/outubro, pp. 587-620.

Silveira 1994. Antonio Maria da Silveira, "Aplicabilidade de teorias: microneoclássica e estratégia empresarial", Revista de Economia Política, vol. 14, n. 2 (54), abril-junho, pp. 53-76.

Silveira 1996. Antonio Maria da Silveira, “A perspectiva da escolha pública e a tendência institucionalista de Knight", Revista Brasileira de Economia, vol. 50, n. 1, jan-mar, pp. 111-113.

Royal Academy 1979. The Royal Swedish Academy of Sciences, "The Nobel memorial prize in economics 1978", The Scandinavian Journal of Economics, 81(1), pp. 72-73.

Wiley 1979. Norbert Wiley, "The rise and fall of dominatint theories in american sociology", in William E. Snizek; Ellsworth R. Fuhrman; e Michael K. Miller (eds.), Contemporary issues in theory and research: A metasociological perspective, Wesport, London: Greenwood Press, pp. 47-79. 